verschillende plaatsen in den tuin leggen, opdat door die zware aarde de rijst ook zwaar zou worden.

Tegen sprinkhanenplaag raadt men aan water gemengd met o loloro, dat is een soort plant, die aan het strand gevonden wordt, en vreeselijk snel groeit. Ook zou dat helpen, als de rijst zich niet behoorlijk ontwikkelt. Èn tegen sprinkhanen, èì tegen walang-sangit, wendt men nog allerlei middelen aan, meest door gomateres gemaakt, en natuurlijk gewoonlijk met niet het minste gevolg. Bepaalde middelen weet men er niet tegen, en het eenige, wat tegen sprinkhanen tenminste helpen zou, n.l., gezamenlijk hier en daar in de alang-alang het aankomende broed verdelgen, daartoe is men niet actief genoeg. Men laat het liever op allerlei middeltjes aankomen, met het gevolg, dat men niets overhoudt. Want men kan zich haast niet voorstellen, wat sprinkhanen vernielen, als ze als bepaalde plaag optreden. Het gewas van den mooisten tuin is dan na een half uur spoorloos verdwenen.

Een bepaalde plaag zijn dikwijls ook nog de rijstvogeltjes, o totoai, die soms in vreeselijke zwermen op de tuinen neerstrijken. Men tracht die op allerlei wijze te verjagen, maakt ook wel allerlei geluidgevende dingen, als in den wind gehangen holle bamboes om ze af te schrikken, maar toch vernielen ze dikwerf nog veel. Wij hebben wel eens geprobeerd om tweemaal per jaar een rijsttuin te maken. Dat gaat heel goed, en men wist dat ook wel, alleen maar, daar dan alle rijstvogeltjes tezamen op die ééne tuin aankomen, is het niet te doen. $\mathrm{Na}$ tuurlijk, maakte elk tweemaal per jaar een tuin, dan was het niets, maar een enkele tuin is haast niet te verdedigen tegen de vraatzucht dezer mooie vogeltjes.

Omtrent den dag, het gunstigst voor het begin van den rijstpluk, zijn de gevoelens nogal verdeeld. Bepaalde goede en booze dagen, kent de Tobelorees niet. Maar toch heeft hij wel voorkeur voor sommige dagen.

Echter omtrent den begindag zegt de een: men beginne het liefst op Woensdag of Donderdag. Een ander zegt echter beslist: men mag niet op Woensdag beginnen, hetgeen door een ander nog weer versterkt wordt met te zeggen: niet op Woensdag, want dat is een dag der bloedstorting! Hoe men daaraan komt, weet ik niet te verklaren. De beste dagen om te beginnen zijn Maandag en Donderdag, volgens weer een ander, en één beweert 
zelfs: de beste dag om te beginnen is Vrijdag. Dat laatste is nu zeker met het oog op de Mohammedanen, heel curieus! Het is dus niet zeker te zeggen, welke dag de beste is.

Vóór dat men met den pluk begint, moet men den tuin binden, voor Bobereki, het rijstoudje, en moet men den rijstgeest, o pine ma gikiri (dus niet bobereki) roepen, opdat de rijst veel zij, en de zegen der rijst niet weg vliege. Want daar is men heel bang voor, vooral ook als men buren heeft die nijdig zijn. Die zouden door bezwering de rijst over kunnen brengen naar hun tuin.

Ook is men nog al heel bang voor wo kuhu, vervloekingen van slechte menschen, waardoor de rijst verrotten zou.

Voor het laatste laat men, als men het vermoedt, door een gomatere medicijn maken, o wokuhu ma houru.

$\mathrm{Om}$ het wegvliegen te beletten, moet men den tuin binden, maar de methodes die men daartoe heeft, zijn nogal verschillend.

De een bindt op elke hoek van den tuin 5 rijstaren bij elkaar, en ook 5 in het midden. Daarna plukt men in het midden een bosje, met wortel en al uit den grond, en hangt dat in de rijstbergplaats, na het alvorens met gemberwortelsap bespogen te hebben.

Anderen binden aan elk bosje aren, nog een bosje bladeren als medicijn om booze invloeden af te weren.

Weer anderen binden alleen midden in den tuin een bosje bij elkaar, en vangen het oogsten nu aan rondom dat vastgebonden bosje, daar eerst alle aren afplukkende eer men tot de generale pluk overgaat.

Op het binden volgt dan het aanroepen of roepen van den rijstgeest, waarna de tuin plukklaar is.

Anderen echter maken eerst naast den tuin een klein hutje, versierd met jonge palmbladeren (o bilere), waarna men vervolgens een klein beetje rijst plukt, dat ontbolstert en kookt, en het op een bord in het huisje zet als het deel van het oudje. Daarna pas meenen ze te mogen beginnen met plukken.

Er zijn er die zeggen, dat het stuk, dat geplukt wordt met dat doel, een vierkante vadem groot moet zijn, en dat de rijst geroosterd moet worden in vier of vijf bamboekokers die men dan in het versierde huisje zet voor het oudje.

De aanvang wordt door anderen ook weer uitgesteld, tot twee dagen na het binden en roepen. 
Algemeen vindt men het noodig de rijst eerst te bespuwen met het sap van gemberwortel, alvorens men met het plukken begint. Ook moet men daarmede de plaats bespuwen, waar men de rijst voorloopig zal opbergen. Is de tuin eenmaal gebonden, dan mogen vreemden, d.w.z. lieden uit andere kampongs, daar niet meer langs loopen, dat is niet beleefd. Dat is natuurlijk met het oog op het medenemen van den zegen, of het vervloeken.

Men moet volgens sommigen aanvangen met opkomend getij, niet met ebbe. Het laatste zou den zegen doen wegvloeien.

Elke plukker wendt het aangezicht naar het Westen, en verandert die houding ook niet. Men plukt dus met de zon meegaande. Waarom die houding zoo is, weet ik niet.

Volgens sommigen, mag men de kleederen, die men bij het begin van den pluk aanheeft, niet mee uit den tuin nemen, maar men moet die, als men den tuin verlaat, in het tuinhuis verwisselen met andere. Of dat is opdat niet de een of andere booze invloed, van buiten den tuin, aan de kleederen blijve hangen, weet ik niet, maar misschien is het zoo iets.'

In diezelfde lijn ligt, dat men de rijstmesjes niet uit den tuin mee mag nemen, maar dat men die in de rijstschuur moet achterlaten.

Algemeen is men het er over eens, dat men tijdens het plukken wel met elkaar mag praten, maar niet al te luidruchtig, en ook mag men volstrekt geen wind laten, daar dat een onbeschoftheid zou zijn tegenover Bobereki, die daardoor boos zou worden, waarna de euveldader buikpijn zou krijgen. Maar menschen van buiten mogen de plukkers niet aanroepen, dat is beslist verboden, en doet de een of ander het toch, dan geefit de geroepene geen antwoord. De roeper van buiten zou de 0 pine ma gikiri meenemen.

Ook mag een plukker wiens korf nog niet vol is, niet door de andere plukkers aangeroepen worden, angezien hij dan zijn korf : niet meer vol krijgt, daar door den schrik de zegen weggevlucht is.

Krijgt men tijdens den pluk bezoek in den tuin, en de bezoekers vertrekken weer, dan moet de eigenaar eenige knoopen leggen in de waaierpalm bladeren, waar men oorspronkelijk mee heeft gebonden, opdat niet de bezoekers den zegen medenemen, en er het volgende jaar veel minder rijst zij.

Woont een der plukkers aan de overzijde van een rivier en 
gaat hij des avonds naar huis, dan mag hij volstrekt niets van het geplukte meenemen over het water, dat zou den zegen doen vervloeien.

Volgens sommigen mag de eigenaar van den tuin zich tijdens den pluk niet in zee baden. Waarom dat verboden is, weet ik niet.

Een ander maakt het echter nog erger door te zeggen: men mag zich gedurende den heelen rijstpluk niet baden. Ja zelfs zegt één voorschrift, dat men zich niet baden mag, tot het offer aan bobereki gebracht is. Dat is dus nog al iets, temeer daar de Tobelorees gewoon is, zich dagelijks te baden. Of men soms meent, dat daardoor de rijst verrotten zal?

Heel verstandig zegt een voorschrift: men mag geen vuur in de rijstschuur brengen.

Pas vier dagen na het begin van den oogst, mag men van de rijst koken, en ook vier dagen na het begin mag men langs den tuin loopen.

De gebonden bosjes laat men tot het allerlaatste staan, en plukt ze dan af, ik meen, om ze voor bobereki in de rijstschuur te hangen.

Het rijstplukken doet men niet gezamelijk zooals het planten, elke familie plukt voor zichzelf. Wel nemen lieden, die groote tuinen hebben, extra plukkers of pluksters aan, die dan echter niet voor loon werken, maar voor een deel der door hen geplukte rijst. Voor vrouwen die tijdens den planttijd ziek waren, is dat nog wel een kansje om ook nog wat rijst te krijgen.

Aangezien men niet voor den voet afplukt, maar alleen de rijpe aren afsnijdt, en dus begint met de eerstrijpe, o riaka, duurt de rijstpluk een geruimen tijd, soms wel drie weken, eer men alles binnen heeft.

Alvorens en tijdens men nu de rijst uit het tuinhuis naar het woonhuis of naar de rijstschuur bij het woonhuis brengt, heeft men nog allerlei bepalingen in acht te nemen, b.v. alvorens de rijst binnen te brengen in de rijstschuur, moet men daar een plaats afzonderen voor bobereki, en daar moet men des nachts een lamp branden. Ook mag men daar geen leven maken of tegen den wand krabbelen want dat geeft het oudje buikpijn, hetgeen. ze natuurlijk wreekt door het volgend jaar de rijst te doen verminderen. Alvorens van de nieuwe rijst zelf te eten, moet men er een bamboekoker vol van koken, echter zonder die yooraf te wasschen, als het deel van het oudje. Men doet 
en wringt, om het meel van de houtvezels te scheiden. Het water waarin het meel opgelost raakt, loopt in een groote lange bak, die er onder staat, ma poko a mo, de groote buik, waarin het meel bezinkt, terwijl het water na de bezinking, afvloeit. Of het meel mooi wit zal zijn, hangt er voornamelijk van af, welk water gebruikt wordt. Is dat mooi helder rivierwater, dan gaat het. Maar dikwijls heeft men maar een soort putje gegraven, met modderig water, en natuurlijk is dan het product niet heel zuiver.

Het meel in den zinkbak bezonken, wordt, nadat de heele boom geklopt is (als tenminste de bak zoo groot is) in een soort pakken gedaan, gemaakt van sagoebladeren (o hangkole). Dit werk heet ho huruku.

Men eet het sagoemeel, op allerlei wijze toebereid. Aangemengd als stijfsel, heet het o gule-gule. Gewoonlijk wordt dit opgegeven als verboden spijs voor lijders aan bere-bere en buikwaterzucht.

Gebakken in vormen noemt het o keteko hoewel men in het Kausche met o keteko, de sagoe zelf aanduidt, en dien dan onderscheidt in rauwe: o keteko ma go, en gebakkene: o keteko ma dutu. Ook eet men gaarne, vooral op zeereizen de sagoe versch in bamboekokers geschud en dan daarin boven het vuur gebakken: o boko-boko. Dit voedsel blijft lang versch, en smakelijk om te eten. Ook bakt men ze wel in drooge bamboekokers, waarin ze duurzamer wordt, maar niet zoo smakelijk. Om ze op de plaats waar men werkt, zelf te bereiden, maakt men er een stijve massa van, plakt die om bamboekokers, en bakt ze dan boven het vuur: ha gogopa. Ook wel vouwt men de sagoe in bladeren om ze daarin te roosteren: ha pola, kneedt ze ook wel tot een bal, om die in het vuur te leggen tot hij gaar is: ha pululu, en bereidt ze ook nog wel gewoon in een ijzeren pan boven het vuur ho hinjole.

Men heeft dus heel veel methoden om sagoemeel te bereiden.

Wat nu de voorschriften enz. bij het kloppen betreft daaromtrent het volgende. Indien men een sagoeboom wil kloppen, die dicht bij een pad of den openbaren weg staat, is het goed die eerst te begieten met bepreveld water, want het is mogelijk, dat er menschen langs geloopen hebben met een o uru jo $\mathrm{h}$ a u ku, een heeten mond, m. a. w. de een of ander kan best 
uit boosaardigheid den boom gevloekt hebben, ho wokuhu, en daartegen is het goed een medicijn aan te wenden. Baat het niet, het schaadt ook niet.

Alvorens men den boom omhakt, moet men een teeken maken en uitroepen: haro kafoika! Haro: heil, voorspoed, kafoika: naar de asch, als asch, opdat de inhoud veel zou zijn, en het meel zacht en gemakkelijk te kloppen als asch. (De eene boom is veel moeilijker te kloppen dan de andere, ook al zijn beide van de zelfde soort).

Men mag den boom maar niet ten allen tijde omhakken, maar men moet het doen bij het opkomen der zon, als de morgenwind de bladeren doet ritselen. Want de inhoud (misschien de gikiri?) gaat des nachts uit vrijen, en het ritselen der bladeren is het teeken, dat zij terugkeert in den boom. Omhakken vóór dat uur, zou dus alleen een ledige boom opleveren.

Tijdens het omhakken moet men zonder ophouden roepen: dola. Dat is n.l. de naam van den inhoud, van het merg, en door te roepen op deze manier komt die, gesteld dat ze uit wandelen was, in den boom terug.

Ik denk, dat al deze bepalingen hun oorsprong vinden, in het verschil in het meelgehalte van het merg van den een of den anderen boom. Twee boomen, die op het oog precies hetzelfde zijn, leveren daarom nog lang niet evenveel op. Natuurlijk is daar een reden voor, b.v. in de plaats waar de wortels van den boom voedsel zoeken of zoo, maar voor den Tobelorees zijn die dingen verbazingwekkend, en bij zijn animistische denkwijze legt hij ze zoo uit, dat in alle boomen evenveel is, maar dat de opbrengst ervan afhangt of de gikiri al of niet uit den boom gaat, en dat er dus alles van afhangt, dat men den boom doodt, met de ziel er in.

Is de boom gevallen, dan neemt men een spaan en gooit die naar den top van den boom. Daarna gaat iemand naar den top toe, en begint nu die met dien spaan, zacht maar langdurig te bekloppen, Het doel daarvan is, dat al het meel uit den top gaan zou, en afdalen naar het gedeelte van den stam, dat men kloppen wil. Pas na dit kloppen, mag men den top van den boom afhakken.

Het omhakken van den boom mag in geen geval gebeuren, door wien den boom geplant heeft. De eerbied, dien men koestert voor den sagoeboom laat dat niet toe. De boom is als Dl. 78. 
een lid van het gezin, zegt men. Hakt dus de planter dien om, dan is hij eigenlijk een moordenaar. Logisch zou dus dat ook wel op andere boomen toegepast moeten worden, maar dat is toch het geval niet, het geldt alleen den sagoeboom.

Ook moet men den top weer in den afgehakten stomp steken, aldus den boom in het idee brengende, dat hij nog compleet is. Doet men dat niet dan moet men wel de wraak van den boomgeest vreezen.

Tijdens het kloppen neemt men nu verder geen bepalingen in acht, behalve dan dat men het niet gewenscht vindt de sagoe in pakken te doen vóór men den geheelen boom geklopt heefit.

Als het kan heeft men natuurlijk liever dat niemand komt kijken tijdens het kloppen, maar bepaald verboden is dat toch niet.

Maar wel is dat verboden tijdens het uitscheppen van de sagoe uit den spoelbak: ho huruku. Vóór men daartoe overgaat, moet men alle toegangen tot het terrein afsluiten met een soort bladeren, o bobugo geheeten, verbodsteekenen dis. Immers kwam een vreemde er bij tijdens het opscheppen, dan zou de ziel, de gikiri, wegulieden, en de eigenaar had de schade. Nadert soms iemand toch nog van de een of andere zijde, dan roept men angstig; pst' $\mathrm{mi}$ huruku, stil, we zijn aan het opscheppen, waarna natuurlijk elk fatsoenlijk mensch terugkeert.

Alvorens op te scheppen, moet men op al de gebruikte gereedschappen, de hamer, de waterschepper enz. een weinig sagoemeel leggen. Het is alsof men deze helpers eerst hun portie wil geven eer de mensch neemt.

Men mag ook niet de sagoe meten voor het opscheppen, of onder elkaar een schatting maken van het aantal pakken dat in den bak zijn zou. Dat is beleedigend voor de gikiri, alsof men hem wantrouwde, hij zou ook daardoor nog heengaan. De heele handeling geschied in diep stilzwijgen zoo mogei.jk, want alle praten brengt het gevaar mede, dat de gikiri er door schrikt, en er van door gaat.

Is eenmaal alles in de pakken gedaan, dan bekommert men zich verder niet om de gikiri.

Omtrent het planten van boomen beweert men het volgende:

Men moet een boom, opdat die veel vruchten zou geven, alleen planten met volle maan. Zooals de grootte van de maan, zal ook de vruchtbaarheid van den boom zijn.

Wat de dagen betreft, is Zondag of Maandag het voordeeligste, (ik weet niet waarom). 
De beste tijd van den dag is 's avonds, want een boom des avonds geplant geeft nog klein zijnde al vrucht, maar een boom des morgens geplant, wordt heel lang alvorens vrucht te geven. Hierbij denkt men aan een kokospalm, o ig o no waarvan de een heel hoog zijnde, pas vrucht geeft - hoogst onvoordeelig maar de ander reeds heel vroeg begint te dragen. Dit verschil ontstaat ten eerste door de soort, en ten tweede, door de grond waarop men plant. Daar dat nu echter weer de aandacht ontsnapt zoekt men het in zulke dingen. Men denkt waarschijnlijk bij het 's ochtends planten, aan den langen dag, die de zon nog voor zich heeft alvorens te dalen, en bij het 's avonds planten, dat de zon spoedig daalt. Ook zegt men nog: wie een kokosnoot plant, moet al zijn kinderen op den rug dragen, tijdens die handeling opdat de vruchtbaarheid groot zij!

Anderen zeggen wie een kokosnoot plant, moet; zich, tijdens die handeling door heel veel menschen laten omhelzen, als het kan een stuk of tien, want daardoor wordt de vruchtbaarheid van den boom verhoogt. Als men dus maar bemind vleesch heeft!! (Ik denk haast dat al die menschen elkaar gelijktijdig moeten omhelzen, zoodat ze een groot kluwen vormen en dat men daardoor groote trossen vruchten aan den boom verwacht). Nog zegt men, dat de planter zelf de eerste vruchten van een boom niet mag plukken. Hij mag er wel van mee eeten, maar ze niet zelf plukken. Later is het van geen invloed meer, wie er plukt.

Wil het geval, dat een boom langen tijd onvruchtbaar blijft, dan beweert men, dat dit een mannelijke boom is. Men doet hem dan, bij wijze van geslachtswisseling, een lap om als een sarong, opdat hij voortaan als vrouwelijk exemplaar, vrucht drage.

Velen echter beweren, dat men dat niet te allen tijde kan doen, alleen maar als o pariama i uihi, d. w. z. als een zeker soort spoelwormen uit de koraalsteenen langs de kust, in zee kruipen. Dit geschiedt elk jaar tot driemalen toe, telkens met een maand verschil, en men schijnt dien tijd als min of meer kritisch te beschouwen, waarom men zegt dat ook de boom dan juist, door hem met een lap te omwikkelen, vrucht gaat dragen.

Men regelt zich bij den landbouw, zooals trouwens bij de heele tijdrekening, naar den stand van het zevengesternte: o paria ma. Niet alsof men neemt, dat dit gesternte zelf eenigen invloed 
zou uitoefenen op de gewassen, maar het wijst den tijd van het jaar aan.

Men noemt het zevengesternte o pariama, en ook het jaar noemt men zoo, even als nog verschillende dingen of gebeur. tenissen, die geregeld jaarlijks terugkeeren.

\section{HOOFDSTUK 25.}

\section{Huisbouw en Meubilair.}

Het Tobeloreesche huis is voor de behoeften van het volk zeer voldoende ingericht. Het heeft een achthoekigen vorm, sommigen ook zeshoekig (zie de schets). De grootte is verschillend, maar men heeft wel huizen van 10 Meter lang, sommige nog langer zelfs. Dit hangt af van de grootte der familie want men heeft de neiging om met vele gezinnen samen te wonen d.w.z. in het huis in het dorp, want men heeft daarnaast nog voor elk gezin apart een tuinhuis. Aan dat laatste wordt echter minder zorg besteed, hoewel men een sterke neiging heeft, de familiehuizen in het dorp te verwaarloozen, en uitsluitend in de tuinen te verblijven. Het tuinhuis wordt dan langzamerhand grooter, en bij een slap bestuur krijgt men een ontvolking der dorpen, en een wonen in de verspreid liggende tuinen.

$\mathrm{Bij}$ de Kausche Tobelo's is dit euvel nooit zoo groot, omdat men daar meer gezamenlijk leeft, met als middelpunt de halu, maar de Tobelos uit Tobelo zelf hebben groote neiging, om zich over de tuinen te verspreiden, en daar ieder in zijn eigen hut te verblijven.

Vroeger is dat niet zoo geweest, omdat toen de oude instellingen nog in eere gehouden werden, maar nu is het wel zoo.

Wat nu betreft een familiehuis, dat behoort eigenlijk te zijn een o hohonotoko ma tau, d. i. een huis, waarvan het geraamte der wanden bestaat, uit met den beitel bewerkt hout, terwijl dat geraamde verder aangevuld is met o utongo, in elkaar gepaste sagoebladsteelen.

Men treft ook nog wel aan, dat sommige gedeelten der bewanding, en vooral de voorwand, uit planken bestaan.

Het middengedeelte rust op vier in den grond gegraven palen, en daar omheen is de rest gebouwd. De Tobelorees is kunst- 

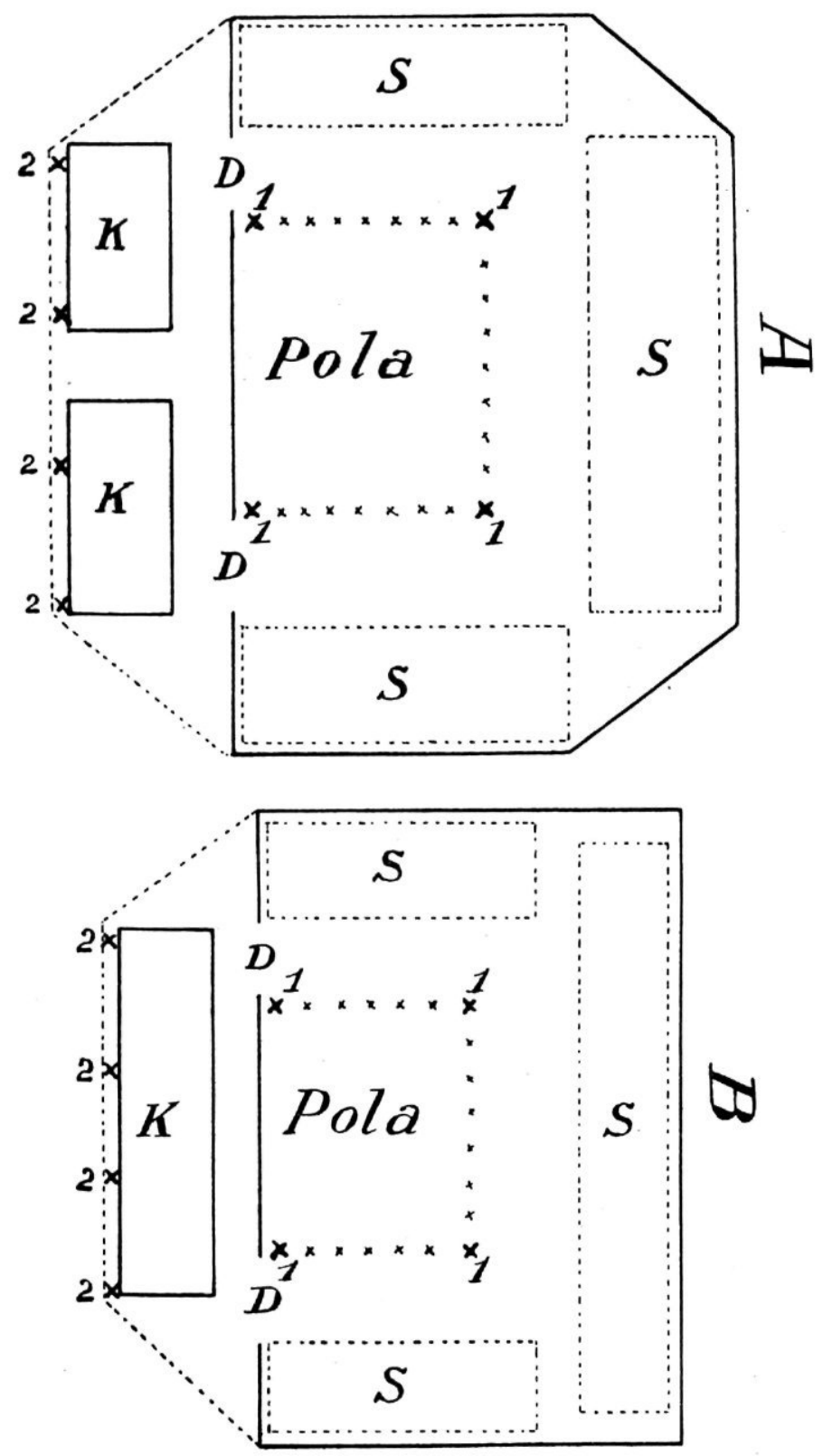

PLATTEGROND VAN TOBELOREESCHE HUIZEN.

1. middenpalen, waar het huis op rust.

2. voorgaanderij-palen.

K. kokiroba.

D. deuren.

S. slaapbanken. 
vaardig, en hoewel zijn gereedschappen primitief zijn, weet hij toch werkelijk wat goeds voor den dag te brengen.

Hij gebruikt slechts een kapmes, o dia, en een soort zelf gesmeede, uiterst smalle beitel, o hohonotoko, maar weet daarmede in den regel ook tamelijk goed om te gaan.

Wel zijn er eenigen, die meer bepaald den naam hebben timmerlieden te zijn, omdat ze een o tukanga ma gikiri, een timmergeest hebben, die dikwerf van vader op zoon overgaat, maar toch weten de meesten, ook zonder nu speciaal timmerman te zijn, toch zelf hun huis wel te bouwen.

Het dak bestaat uit o katu (Mal. atap), om smalle latjes genaaide sagoebladeren. Hiervan kent men twee soorten. Bij de slechtste soort, die men o jaba-jaba (Ambonsche) noemt, worden de bladeren om een latje genaaid, waarbij de bamboeschil, waarmede men naait, door dwarspennetjes voor doorscheuren bewaard wordt. Deze soort is niet heel duurzaam. De betere soort, o bilatu, wordt gemaakt met behulp van een tweede latje, dat tegen het eerste aangelegd wordt, zoodat bij het naaien de bladeren ingeklemd worden, ho pilat u, tusschen deze twee latjes in. Aangezien men voor deze soort de sagoebladeren veel dichter op elkander legt, is ze veel duurzamer. Een dak hiervan vervaardigd, kan wel een jaar of vijf, zes liggen.

Zorgt men voor het onderhoud van het dak, zoodat de regen het hout niet doet rotten, dan kan zoo'n goed huis wel dertig of veertig jaar staan.

Daar men het overstekende dak, de detoro, gewoonlijk niet heel breed maakt, zijn de buitenwanden nogal blootgesteld aan natregenen, waardoor de bewanding wel eens vernieuwing noodig heeft. Verven of witten doet men de buitenwanden niet, hoewel men wel eens de voorwand kleurt, wit of geel.

Het huis is, naar onze begrippen, laag van verdieping. Een lang persoon kan niet dan bukkend naar binnen komen, maar, daar het dak sterk helt, is meer naar binnen ruimte genoeg.

Over het geheel, zijn de huizen tamelijk koel, en men bouwt ze gaarne op een beschaduwde plaats.

Naast deze goede huizen, bouwt men er echter ook heel wat van minder allooi. Voor het tuinhuis gebruikt men bijna uitsluitend bamboe, en het moet gezegd worden, dat de Tobelorees die bamboe met zijn kapmes verbazend handig weet te bewerken, 
Ook maakt men de wanden wel van sagoebladeren, losjes aan elkaar genaaid of geregen, o halipi; dit is echter al eenigszins minderwaardig.

Men kookt en stookt niet in het huis, behalve soms in een tuinhuis, maar in een apart gebouwtje o hohakai, de keuken. Dit is gewoonlijk uiterst primitief gebouwd, niet ver van het groote huis af. De vrouwen houden daar gewoonlijk overdag verblijf.

Voor het bouwen van een huis heeft men allerlei bepalingen, als b.v. dat men de plek voor het nieuwe huis niet mag af branden, anders zal het huis later ook afbranden. Men heeft n.l. de gewoonte, wanneer men een plek schoon maakt, het vuil en onkruid te laten liggen, totdat het droog is, en het dan eenvoudig in brand te steken. Dat mag dus niet voor een plek, waarop men een huis wil bouwen.

Men mag het huis ook niet bouwen op een plaats, waar vroeger graven (lijkenhuisjes) waren, want dan zullen booze geesten de plek bezoeken. Volgens sommigen, moet men uiterst voorzichtig zijn met het uitmeten van de plaatsen der palen, de plaats voor de deuren, kortom met al de maten want het huis staat in verband met het lichaam van den eigenaar. Zijn de afmetingen goed genomen, dan zal ook het lichaam van den eigenaar goed zijn, maar zijn de maten ongelijk, dan raakt ook het lichaam van den eigenaar ongelijk, in wanorde dus, en hij moet sterven.

Volgens anderen, moet men in de gaten voor de palen bestemd, eerst een mengsel gieten, bestaande uit suikerstroop en kokosolie, opdat de huisgenooten niet twisten, maar hun hart zoet als stroop zij, en glad en meegaand als olie.

Volgens weer anderen, mag alleen het oudste kind des huizes de palen oprichten. De reden hiervoor is mij niet bekend; misschien denkt men aan de kracht van dat kind, of het lange leven dat het nog voor zich kan hebben, om daardoor invloed op de duurzaamheid van het huis uit te oefenen.

Onder de palen moet men, volgens den een, allerlei genezende bladeren leggen opdat de a.s. bewoner geen last zou hebben van hoofdpijn.

Volgens anderen, moet men onder de palen bladeren leggen van een vetplant, o mamata: koude, opdat in het huis geen twist ontsta, manga hininga ja haukua, hun hart niet heet, driftig zij. 
Aangezien er nu gewoonlijk nog wel eenigen tijd verloopt, tusschen het zetten der palen en het afwerken van het huis, plant men bij de palen ook wel o mamata, eerst afwachtende of dat groeien wil. Sterft dit, of wil het niet groeien, dan moet men de palen verplaatsen; de plek is $\mathrm{ja} h \mathrm{haku}$ heet, en dus niet goed. Men zou in het huis onafgebroken ziek zijn.

Ook plant men bij de palen wel gandarusa, een soort heester met een eigenaardige lucht, die aan herten doet denken. Ik weet niet of dat misschien is, opdat de eigenaar gelukkig zou zijn op de hertenjacht.

Nog plant men een zeker kruid o roring o ham a geheeten, wellicht om de beteekenis: ngohama van wohama: ingaan, hingohama: in doen gaan, in doen brengen, opdat er veel zegen of voorspoed ingebracht zal worden.

Maakt men de kap, dan worden de stukjes hout, die afgezaagd of afgekapt worden, alle bijeenvergaard, en in een bosje boven in het huis vastgebonden. Men wist mij niet te zeggen, waarom dit was, maar ik denk, om te voorkomen, dat ze als brandhout gebruikt worden. Het hout is bestemd voor het huis, dus zal men wel bang zijn, dat het verbranden van gedeelten ervan, het afbranden van het geheel ten gevolge zou hebben.

Natuurlijk dat voor het opleggen der dakbedekking de vrienden en geburen tezamen komen, en even natuurlijk, dat men na volbrachten arbeid een feest viert. Dat feest wordt door velen meteen als inwijdingsfeest beschouwd, en men betrekt dan daarna het huis.

Maar anderen zijn niet zoo lichtvaardig. Volgens velen moeten den eersten nacht uitsluitend vader en moeder in het huis slapen, of liever: overnachten, en heel goed luisteren of zij ook verdachte geluiden in het huis hooren. Hooren ze die, dan is dat een bewijs, dat er tokatas, booze geesten in het huis wonen, en men moet nu eerst bezwerend water maken om het huis te begieten, om ze te verdrijven.

Anderen nemen het nog veel secuurder. Op al de samenvoegingen van het huis moet geestenwerende medicijn gelegd worden, bamboekokertjes met bezwerend water moeten bij den ingang geplaatst worden, allerlei geheimzinnige lapjes en amu. letten, moeten aan de wanden bevestigd, hoe meer hoe liever. En natuurlijk moet nu ook eerst een gom a te re geraadpleegd worden, die moet mededeelen of het huis goed is, dan wel 
dat er booze geesten in zijn (en die zijn er altijd als een go$\mathrm{m}$ atere het onderzoekt) om ze daarna te verwijderen. Daarna pas kan men dan het inwijdingsfeest vieren, en het huis betrekken.

Het spreekt vanzelf dat men voor een tuinhuis zooveel moeite niet doet. Dat is geen vaste verblijfplaats, dus is het ook niet noodig er veel voor te doen.

Toen wij ons op Tobelo vestigden, viel ons oog op een vlakte als 't meest geschikt voor woonplaats. Het huis werd daar gebouwd, maar men voorspelde, dat wij daar niet veel geluk zouden hebben, want het stond juist in het midden tusschen een groote waringinboom (geesten-verblijfplaats), en de badplaats. De geesten die gingen baden, zouden zich dus gestoord gevoelen. Een der bouwers stierf, natuurlijk al door de toorn der geesten (de man had zich doodgedronken aan palmwijn), en men meende, dat het ook ons er kwalijk vergaan zou. Echter, toen het huis er eenmaal stond, kwam men er toch gaarne, om zich te laten medicineeren. Maar aanvankelijk wilde men niet gaan zitten, bang daardoor bij de geesten als bewoners te gelden. Maar daar kwam men spoedig overheen. Met Kerstfeest echter kookten wij een feestmaal voor de menschen. De spijs stond klaar, maar helaas, hoevelen er ook om heen stonden, binnen komen en gaan zitien eten, wilde niemand. Dan zou men voor bewoner gelden, en de wraak der geesten moeten vreezen. De spijzen mee nemen wilde men wel.

Hoe men het nu aanlegt, om in een tijdelijke verblijfplaats niet te eten, om niet als bewoner te gelden, en er toch langdurig te verblijven, weet ik niet.

De zucht om wat men maakt, te versieren is aan de huizen soms zeer goed waar te nemen. Het is niet bepaald moo $i$ wat men maakt, maar toch uit zich de kunstzin b.v. in het maken van prachtig uitgesneden palen voor de voorgaanderij. Ik heb er gezien, waar men jaren lang aan gewerkt had, sommige zelfs uit ebbenhout gemaakt, zoodat men niet weet wat het meest te bewonderen, het geduld, of wel de kunstvaardigheid, met primitieve gereedschappen zooiets tot stand te brengen.

Ook brengt men snijwerk aan op de balken van de kokiroba, men makt mooi uitgesneden stukken boven de deuringangen, ook wel als versiering in den middenwand.

Zelfs uit men dien kunstzin in het leggen van de dakbedekking, waarin men allerlei bloemen en versieringen weet aan te brengen. 
Men bouwt de huizen zelden dicht bij elkaar. Gewoonlijk staat elk huis op een nog al tamelijk groot erf. Volgens de oorspronkelijke bouworde staan ze eenigszins in het rond, tezamen als op een groot plein, en in het midden ongeveer staat de halu.

De ruimte voor het huis is gewoonlijk ledig, omdat men daar plaats moet hebben voor feestvieren, maar op zij en achter het huis vindt men alles beplant. Men vindt daar allerlei specerijen, en ook vooral veel soorten bloemen, want daar is men dol op. Voor de rest wordt het erf onkruidvrij gehouden, en gewoonlijk elken morgen behoorlijk geveegd, zoodat een Tobeloreesche kampong, (tenminste als het niet is in den tijd-dat ieder in de tuinen is) geen onaangenamen indruk maakt.

Wat de inrichting betreft, is de voorste ruimte, het voorste trapezium zou men kunnen zeggen, een open gaanderij, terwijl de ruimte, ingenomen door het rechthoekige middenstuk, en het achterste trapezium, omwand is. Tusschen de voorgaanderij en het middenstuk heeft men den voorwand, waarin aan weerskanten een deur. Door de vier palen, waarop het middenstuk rust wordt inwendig een vierkant gevormd, een ruimte, of tot bewaarplaats, ò tot Djini-dansplaats gebruikt, en daaromheen loopt een gang waartoe de deuren aan weerskanten toegang geven. Tusschen dien gang en den buitenwand zijn de slaapplaatsen. Staande vóor het huis, met het aangezicht er heen gewend, heeft men rechts de slaapplaatsen der gehuwden en links die der jongelui.

In verband met die inrichting is het een vreemdeling verboden, een huis rechts binnen te gaan, daar dit duiden zou op ongeoorloofde nieuwsgierigheid naar de handelingen van gehuwden onderling. Het heet: de slaapplaats der schoondochters, en daar binnen te dringen is strafbaar. Wel zijn de slaapplaatsen door gordijnen van den gang en van elkander afgescheiden, maar toch is dat niet genoeg om onbescheidenheid uit te sluiten.

Het meubilair is in den regel niet heel veel van beteekenis. In de voorgaanderij is het voornaamste stuk de kokiroba, de groote bank met in den grond gegraven pooten. Van boven is hij belegd met platgeklopte bamboe. Deze bank is pl.m. 75 centimeter hoog, en in groote huizen wel 2 Meter breed, soms in het midden nog door een gangetje gescheiden, zoodat het dan twee banken zijn, links voor de mannen, rechts voor 
de vrouwen. Dit laatste echter alleen in de grootste soort huizen. De bank loopt langs de heele lengte van het huis, en is dus zoo lang, als de bovenste zijde van het voorste trapezium.

Het heele openbare leven speelt zich op die bank at. Men zit daarop om gasten te ontvangen, om te eten, om uit te rusten, om feest te vieren, zelfs slapen de jongelingen en oilgehuwde mannen er op, als het weder niet al te guur is.

Dikwerf ziet men aan het eind van de kokiroba ook het aardewerk, dat voor de maaltijden gebruikt wordt, en dat daar wordt neergelegd, om het gemakkelijk bij de hand te hebben, daar de kokiroba ook meteen tafel is. Ook ziet men er gewoonlijk nog een soort stoffer, vervaardigd van arenpalmvezeis. Men makkt zoo'n stoffer door overlangs door het hout een smalle opening te beitelen; daarin steekt men een laag vezels, aan weerskanten zoowat even lang uitstekende, om ze dan vast te klemmen met een ander stuk hout, dat men in de opening brengt. Deze stoffer, o wale ma boharihi, vuilveger, wordt gebruikt om na den maaltijd de kokiroba schoon te vegen.

Tusschen de kokiroba en de voorwand van het huis, is een gang, in grootere huizen nog zóó breed, dat tegen den wand nog een bamboezitbank kan gemaakt worden ook met ingegraven pooten.

Aan den voorwand der woning vindt men als versiering schilden, oude. zwaarden, lansen, oude geweren en dergelijke opgehangen. Men weet ook dat heel smaakvol te doen. Ook hangt men er soms wel hoeden aan.

Ofschoon men hier en daar naast de kokiroba nog een primitieve stoel of tafel ziet, hooren die toch niet bij het Tobeloreesche ameublement. Men treft nu al veel lampen aan, die boven de kokiroba hangen, en waarvan de meeste $u$ in verbazing brengen, bij de idee dat zoo iets vuils en bedorvens zou kunnen branden, maar men heeft toch ook aan het eind van de kokiroba de totodingi staan, een van hout rervaardigde, dikwijls met snijwerk versierde kandelaar, waarop men de harsfakkel, o hilo zet. Sommige hebben een langen voet, en staan op den grond, andere zijn korter, en staan op de kokiroba. Ook zijn gewoonlijk in de eindpalen derkokiroba zelf, insnijdingen gemaakt waarin men een fakkel kan plaatsen.

De slaapbanken binnenshuis zijn meest ook van bamboe, met ingegraven pooten hoewel men ook enkele primitieve rustbanken, 
o bale, aantreft. Het bed bestaat uit een ligmat met een kussen. Soms is die ligmat heel mooi, en ook het kussen kan heel mooi zijn, in den vorm van een rolkussen, met roode versierde lapjes in de uiteinden genaaid.

Gewoonlijk echter zijn de kussens, o nora, o gogerena, afschuwelijk vuil en vies.

In de slaapkamer van een jong meisje, vindt men nog wel eens allerlei versieringen, zoodat het er niet onsmakelijk uitziet, maar vuil is het kussen, en ook soms de ligmat daarom toch evengoed.

Het middenvak van het huis is de bewaarplaats van de familieschatten, bestaande in aardewerk, oud porselein, ook pronkmatten, enz,

Heeft men er een zoldertje in, dan is dat tevens zoowat de bewaarplaats voor kisten met kleederen die men heeft, voor zoover elk die niet onder zijn eigen slaapplaats heeft staan.

Van het oude porselein heeft men verschillende soorten, b. v. b. o harime blauwe schotels en kommen, dikwerf met grove bloemen; o batawe i toka tokara, en i bihi-bihi, rood en blauw; dit is zeer fijn porselein, met zeer fijne bloemen; o gabi ma hoka, een fijn soort, welks bloem wel wat lijkt op jasmijnblad, vandaar den naam: o gabi: enkele jasmijn; o djabiba, een soort blauwe kommen; o sarasa, dergelijke kommen, maar grover; o tarate ma hohoko: lotosvruchten, heel fijn met vergulde bloemen; o tanu-tani, allerlei potjes met deksels, grootere en kleinere, waarschijnlijk gemberpotjes of zoo iets, o hugi, groene schotels, heel grof en zwaar, o dapung, allerlei schotels met drakenafbeeldingen; ma hirahira, zeer oud, allerlei andere soorten, die men niet nader weet te benoemen.

Men heeft groote, platte schotels, ook borden, kommen, vazen, karaffen, sommige zeer groote martavanen, die men op feesten gebruikt, als palmwijnreservoirs.

Men is er zeer aan gehecht, en gaat alleen uit nood tot den verkoop over. Meermalen hoorde ik aan iemand die trachtte het te verkoopen, vragen: wat heb je voor moeite, dat je je porclein verkoopt? Men tracht gewoonlijk ook wel eerst het te beleenen, voor men tot den verkoop overgaat.

Hoe men het oorspronkelijk verkregen heeft, weet men niet meer. Men zegt dat het op rooftochten verzameld is, maar 
waar, dat weet men niet. Dikwijls gelden groote stukken als woonplaatsen van geesten, en geslepen gomateres weten daar heel goed gebruik van te maken om menig stuk, dat zoogenaamd ziekte verwekt, te bemachtigen, voor een appel en een ei.

Men vindt het hier en daar nog wel eens in den grond begraven, waarbij dan gewoonlijk de gelukkige vinder heel angstig is, om het op te delven en te nemen, aangezien het zeker een ma dutu zal hebben, een booze geest, die er rechten op zal laten gelden. Ik hoorde van lieden die een mooie vondst gedaan hadden, maar het weer in den grond gestopt hadden, uit vrees, dat het door een booze geest bewoond zou zijn.

Ik heb het ook zelf wel gevonden, d. w. z. de menschen die het gevonden hadden, verzochten me dan, het uit te graven. Het was gewoonlijk op plaatsen in het bosch, die $\boldsymbol{n} u$ onbewoond waren, waar men het vond tegen hellingen van heuvels, waar de aarde door de regens langzamerhand afschoof. Het maakt den indruk alsof het in der haast begraven of weggestopt is. Waarschijnlijk dus zijn de eigenaars gevlucht voor een vijandelijken inval en hebben het toen begraven. Men doet dat nu nog. Is men bevreesd door het een of ander gerucht, dan begint men dadelijk de schatten te begraven. Daar nu aangenomen moet worden, dat de Tobelo's dit porcelein nog niet in hun bezit hadden, toen ze naar de kust afzakten, daar het eenige stuk, dat men toen had, nu nog als bijzonderheid getoond wordt, zou men wel haast denken, dat men het geroofd heeft van de kustbevolking die men misschien verdreef of zoo. Dat het alles op rooftochten in andere landen bij elkaar gebracht zou zijn, komt me onbegrijpelijk voor. Men heeft ook nog veel koperen schotels, o talama, die men ook bij feestelijke gelegenheden gebruikt.

In de keuken vindt men allerlei keukengereedschap. IJzeren potten en pannen, ook wel van aardewerk. Men koopt dat laatste, want men verstaat niet zelf de kunst om het te maken.

De pottenbakkers uit den Archipel zijn de bewoners van het eiland Mare. Ook koopt men van deze de sagoevormen, o gohoanga, waarin men de sagoekoeken, o keteko, bakt.

Wanneer men niet veel ijzeren of steenen potten en pannen vindt in de keuken, is dat nog geen bewijs, dat er niet in gekookt wordt, want de eigenlijke Tobeloreesche kookpot is de versche bamboekoker. Daarin doet men de spijs, en laat ze er in gaar worden, en de meesten verkiezen het aldus gekookte, 
boven het in potten of pannen bereide, omdat de geur en de smaak van de bamboe, en van de bladeren die men gewoonlijk nog daarin doet als omhulsel voor de spijs, het eten lekkerder maken. Ook smaakt het in pannen gekookte eten gewoonlijk nog al sterk naar den rook, daar men gewoonlijk alleen allerlei bladeren als deksel gebruikt. Die beletten dan wel het invallen van vuil en roet in het eten, maar natuurlijk niet, dat de rook die steeds om de pan heendwarrelt, de spijs minder lekker maakt. Bij koken in een bamboe heeft men daar geen last van.

Verder vindt men bezems van palmbladnerven, o hehehara, bamboe vuurtangetjes, o kakatama, en platte manden van gevlochten bamboeschil, o tatapa, die men voor allerlei gebruikt. Ook kleinere en grootere bakjes en bakken, gemaakt van in elkaar gevouwen bladscheeden van pinang- en sagoepalmen, die als waterbekkens dienst doen en dien dienst ook heel voldoende verrichten.

Ook heeft men allerlei schuim- en scheplepels, o iru-iru, waarvan het blad gevormd is uit een kokosnootdop, en de steel van hout. De lange steelen worden met allerlei snijwerk versierd. Een soort eetlepels maakt men ook uit kokosnootdoppen, en ook gebruikt men die doppen nog om trechters te maken, voor het uitschenken van den palmwijn in flesschen. Men maakt dan onder in den dop een gaatje, waarin men een bamboekokertje steekt, en de trechter is klaar.

Nog heeft men waterscheppers van waaierpalmblad gemaakt, o hia-hia, een klapperrasp o igono ma kokore; dit is een getand rond ijzertje, dat gestoken wordt in een blokje hout, waarop men gaat zitten, om het zoo de stabiliteit te geven, voor het gebruik noodig. Fijne zeefjes om sagoe meel door te zeeven, o dedeta, en waaiertjes van waaierpalmblad, o tataloko, om het vuur aan te waaieren.

Het vuur wordt gebrand tusschen eenige groote steenen o rikana, waarboven men de pot of pan zet.

Naast het huis vindt men nog een soort rek, waartegen men de waterbamboes, o kiloana, zet, en ook gewoonlijk een o dodego, een pers voor suikerriet, en natuurlijk vindt men hier of daar een rijststampblok, o $1 \mathrm{uh}$ u $\mathrm{ng}$ u. Huis, keuken, meubilair, het is alles primitief, maar daarom nog niet onhandig, en voor de behoeften van een primitief volk al heel voldoende. 


\section{HOOFDSTUK 26.}

\section{Vaartuigen.}

Te Tobelorees bouwt een heel goed en zeewaardig vaartuig, o ngotiri. Dat hij over het geheel een kunstvaardig man is, wordt hierdoor praktisch bewezen.

Een volk, dat langen tijd geleefd heeft van zeeschuimen, en nog altijd zwerfziek is, moet natuurlijk ook wel goede prauwen hebben. De behoefte deed hier het noodzakelijke tot stand komen.

De Tobeloreesche prauw is een vlerkprauw. Wel ziet men ook andere soorten, maar die zijn ingevoerd.

Men heeft twee soorten: o ngotiri o kalulu en o ngotiri o böotu.

Van beide is de grondslag de ma leha, de onderlegger. Men gebruikt het woord ook om een vrouwelijk hert aan te duiden, ook voor den duim der hand. Het is dus het onderste gedeelte waar de rest op rust. De kiel is het niet, want het is een hol uitgehakt stuk prauw, waarmede men ook wel zonder meer varen kan. Het is dan gewoonweg een o ngotiri maleha, een prauwtje zonder opgezette planken. In het Ternataansch zegt men $m a$ hera hiervoor, en vandaar den naam Halmahera, onderlegger van het land, waarvoor men dus ook in het Tobeloreesch zegt: o Tonaka ma leha.

Op dit onderstuk nu zet men planken naar believen, hoewel dat believen zich richt naar de lengte van de onderlegger. De hoogte moet aan de lengte geëvenredigd blijven.

Bij de kalulu bevestigt men voor en achter aan de onderlegger een uitstekend stuk hout, en in dat hout worden de uiteinden der opzetplanken bevestigd.

Bij de böotu doet men dat niet; de opzetplanken worden eenvoudig vóór en achter schuin afgesneden, tegen elkaar aangepast, en zoo vastgebonden. Natuurlijk is dat niet zoo sterk als de eerste manier, en men makt op die manier ook zelden prauwen met meer dan één opzetplank. Voor kleinere prauwen is het echter wel een gemakkelijke methode en ook zeer voldoende.

Ofschoon men aan de prauwen een tamelijk groote buik weet te maken, buigt men toch het hout maar heel weinig, maar hakt het reeds eenigermate in den gebogen vorm uit den boom. Dat daarbij heel wat hout weggegooid wordt, spreekt vanzelf, maar daar behoefde men ook juist niet op te zien. 
Men laat bij het hakken, op eenigen afstand van elkaar, aan den binnenkant, klossen zitten aan de planken, zooals ook in de onderlegger.

Bij een middelmatige groote prauw zijn dat er vijf. Deze komen precies boven elkaar, en ook juist tegenover elkaar. Ze dienen om door dwarshoutjes verbonden te worden, met touwtjes, terwijl men dan weer al die latjes of dwarsstokjes, door een stevig touw van boven naar beneden aan elkaar hecht, en daardoor het uit elkaar wijken van de planken voorkomt. Deze klossen heeten o maru-maru, en zijn een voornaam bestanddeel van de prauw.

Men bevestigt de planken op elkaar met houten pennen, o hikata, waarvoor men met een soort inlandsche boor, o gogori, die men meer in het hout klopt dan wel draait, de gaten maakt.

Voor een lange prauw moet men de planken ook in de lengte aan elkaar hechten. Voor die samenvoeging heeft men verschillende methoden of figuren, die een soort familie-eigendom zijn, en hoewel men geen gilden kent, durfde men toch niet elkanders figuren of methode te gebruiken.

Tusschen de planken legt men, alvorens ze op elkaar te bevestigen, een dun laagje breeuwsel, o baru, dat men verkrijgt uit de bladscheede van een palmsoort, ook o baru geheeten. Is de prauw groot, dan holt men zelfs de onderplank eenigermate uit, om er dit breeuwsel in te leggen, dat het doordringen van het water door de naden moet voorkomen. Een goed gemakkte prauw lekt dan ook voorloopig niet.

Heeft men hard hout gebruikt, den duurt het zelfs heel lang eer de prauw begint te lekken. Bij zachtere houtsoorten gebeurt dit eerder, omdat het zeewater tusschen de planken doordringt. Men breeuwt dan ook weer met dit baru, dat werkelijk heel geschikt is voor het doel.

Dat men niet altijd met hardere houtsoorten werkt, heeft voor een deel zijn grond in de mindere vlijt van den prauwenmaker, daar hard hout heel wat moeilijker te bewerken is, dan zachtere soorten, maar toch ook wel daarin, dat men de prauw niet gaarne zwaar maakt, waardoor hij minder snel zou loopen. Heel veel maakt men dan ook de onderleggers en de eerste opzetplank, ma ih anga, van hard hout, dat tegen de inwerking van het zeewater bestand is, maar bezigt voor den verderen 
opbouw lichtere soorten, die men dan ook later gemakkelijk verwisselen kan.

Het snelle loopen is natuurlijk voor een volk, dat het zeeschuimen beoefent, een hoofddeugd voor een vaartuig, en die deugd heeft de slank gebouwde prauw dan ook wel.

Bij de kalulu bevestigt men op de voor- en achtersteven nog een lang opzetstuk, dat schijnbaar doelloos is. Men versiert hct echter gaarne met allerlei snijwerk, en het heeft het nut dat men bij varen in het donker, er gemakkelijk door sturen kan, aangezien de stuurman steeds gemakkelijk ziet, waar juist de voorsteven is.

Over de tweede en vierde rij klossen bevestigt men de dwarsleggers. De prauw heeft die nooit meer dan twee, al is ze ook nog zoo groot. Met stevige banden worden die op de rij klossen bevestigd. Ze zijn meer of minder lang, al naar dat de prauw groot is.

Aan het eind daarlangs, bevestigt men aan kromme houten, o taintena, de vlerken of uitleggers, zóó, dat het geheel goed veeren kan, waardoor het zelden breekt, en ook zoo, dat men, al naar het meer of minder diep liggen van het vaartuig, ze hooger of lager kan binden, zoodat ze altijd zoowat op den waterspiegel liggen, waardoor de prauw tamelijk vast ligt.

Voor vlerken, ma hamana, gebruikt men het liefst dikke bamboekokers, dun van schil, zoodat ze licht zijn, maar door hun groote holte veel draagkracht hebben. Ook wel bedient men zich voor dit doel van lichte houtsoorten. Het voorste gedeelte van de vlerk is iets opgebogen, waardoor zij het water gemakkelijk snijdt. Alles is berekend op snellen gang.

Over de voorste dwarsleggers bevestigt men het toestel om den mast o liaro, aan te bevestigen, o liaro ma gogerena, het kussen voor de mast. Aan weerskanten heeft dit een uitstekende punt. De mast bestaat uit drie bamboestaken, boven bij elkaar gehouden door een doorgestoken pen, die men als een driepoot overeind zet; de twee buitenstaken zijn van onderen doorboord, en worden op de uitstekende punten van het kussen geschoven, terwijl de middenstaak naar voren gebracht wordt, en bevestigd aan de voorste rij klossen, of liever, aan de dwarshoutjes daarvan. Hoog is de mast niet, maar heel gemakkeijk om te hanteeren, zoodat één man die met gemak overeind zet of weer strijkt. Kan men zeilen, dan gaat ook de mast overeind, zeilt men niet, dan strijkt men die ook dadelijk weer. 
Een roer vindt men niet aan de prauw, hij wordt met een riem bestuurd, dat wil zeggen, de man, die op den achtersteven zit te roeien, houdt het stuur er in, door beurtelings links of rechts te roeien. Tijdens het zeilen houdt hij zijn schepper achter overlangs in het water, als roer.

Men kent niet de kunst om het hout door insmeeren met het een of ander duurzamer te maken, ook de naden bestrijkt men niet.

Men bezigt een zeil, langwerpig vierkant, ma hidete, dat tusschen twee bamboestaken bevestigd is. Iets onder het midden zit aan den eenen boom een lus, waarmede men het ophangt aan een haak, bevestigt aan den middelsten maststaak. Men heeft een schoottouw, bevestigd aan den boom waarmede het zeil aan den mast hangt, bijna bovenaan, en een andere aan den tegenovergestelden kant, benedenwaarts, en men weet daarmede het zeil tamelijk goed te regeeren, brengt het over den rechter- of linkerkant naar believen, haalt het meer in de hoogte, of laat het voor zwaren wind van aehteren, meer naar beneden glijden; kortom, men weet er heel goed mee te manoevreeren.

Het zeil is tegenwoordig meest vervaardigd van katoen, maar vroeger, en thans nog wel nu en dan, maakte men het door een soort breede biezen, met behulp van rotandraden aan elkaar te rijgen.

Zulk een zeil trekt beter dan een katoenen zeil, naar men zeide; ook is het heel licht (behalve bij nat worden), maar niet zeer duurzaam.

Bij het zeilen hangt men aan het zeil gaarne allerlei gekleurde lapjes en franjes. Ook beschildert men het heele zeil wel met allerlei fantastische figuren.

Men gebruikt uitsluitend touw, gedraaid uit de vezels der haarnetten van den arenpalm, o kodohu. Dit touw is betrekkelijk heel duurzaam, en natuurlijk overal te krijgen, aangezien de arenpalm algemeen in massa voorkomt.

Voor het aanbinden der vlerken gebruiken sommigen uitsluitend lianen, waaronder sommige soorten in het zeewater ook zeer duurzaam zijn.

Kan men aan het strand een geschikten boom vinden om er een prauw van te maken, dan is dat heel mooi, maar daarmen nogal veel prauwen gebruikt, is op den duur het hout dicht aan het strand, niet voldoende voor dit doel. Men maakt dan de Dl. 78 . 
prauw in het bosch, soms heel ver van het strand, niet zelden met bijna alle opzetplanken, gereed, en sleept die dan later over rollen naar zee. Dat komt ons nogal onpraktisch voor, maar het gaat onder een hoeratje, en met de noodige palmwijn, nogal heel gemoedelijk en vroolijk.

De prauw wordt bij groote uitzondering geroeid; dat is de manier niet; men schept de prauw voort met scheppers, o haremi. Die scheppers maakt men heel kloek en breed, en het handvat is dikwijls heel fraai versierd, door allerlei uitsnijdsels. Deze scheppers behooren echter niet bij de prauw, elke roeier heeft zijn eigen schepper.

Dat men die scheppers heel goed weet te gebruiken, weet ik door jarenlange ondervinding te getuigen. De Tobelorees is een onvermoeibare schepper, en door gezamenlijk scheppen wordt de prauw snel voortbewogen, wijl hij door zijn spitsen vorm het water heel gemakkelijk snijdt. Wel heeft hij niet heel veel laadruimte, juist door dien spitsen vorm, maar het valt toch nog wel mee. Door de vlerken gesteund, kan in het bovenste gedeelte van het vaartuig nog al wat geladen worden.

De Tobeloreezen zelf, praten wel tijdens het roeien, maar zingen heel zelden. Meer doen dat de Kausche Tobelos, die veel houden van het zingen van roeideuntjes, ho kokabata, gewoonlijk een soort beurtzangen, waarbij de roeiers van den voor- en achtersteven elkander toezingen. Soms zijn dat maar een paar regels die onafgebroken op gedreund worden, soms ook weet de een of andere dichter onder de roeiers, allerlei voorvallen tijdens de reis te bezingen, allerlei waarschuwingen, met het oog op zee, op rotsen of klippen, op gevaarlijk strand, ook wel allerlei tot lof van de meisjes aan de kust, enz.

Een eigenlijke zeetaal kent men niet, maar men heeft de gewoonte, bij moeite en tegenwind, zich gaarne van een vreemde taal te bedienen, bij voorkeur van het Ternataansch of Tidoreesch. Daar dat nu in den mond der Tobeloreezen nogal kluchtig klinkt, zeide men mij wel eens, dat alleen de bedoeling was, door het kluchtige der uitdrukkingen de lui aan het lachen te brengen, opdat ze vroolijk zouden wezen, en daardoor beter roeien zouden. Dat het middel in allen gevalle ook die uitwerking heeft, heb ik meermalen met vreugd kunnen constateeren.

Dat een werk, zoo gewichtig als prauwen maken, ook zijn bepalingen en regelen heeft, is wel te begrijpen. 
Men moet eerst den boom, dien men gebruiken wil, beproeven alvorens hem om te hakken. Men begiet hem daartoe met bepreveld water en steekt er een stukje gemberwortel in, in een keepje, dat men er daartoe met een kapmes in maakt. Is dat er den volgenden dag uitgevallen, dan is het een boom met booze geesten, en kan niet voor prauw dienen. Men zou er ongeluk mee krijgen.

Heeft men den boom omgehakt, dan moet men een klein boompje naast den afgehouwen boom planten, opdat de $\mathrm{ma}$ dutu, de ziel of eigenaar ervan, over zijn verlies getroost worde. Men geeft hem dan misschien het nieuwe boompje tot woonplaats. Doet men dat niet, dan doet de ziel van den boom ook de nieuwe prauw verongelukken.

De gereedschappen van iemand die een prauw maakt, mag men niet aanroeren, want, zoo iemand zich daarmede verwondde, zou het alleen kunnen genezen door het opleggen van kippendrek.

Waarom deze bepaling is, weet ik niet. Die gereedschappen zijn anders nogal hoogst eenvoudig; een kapmes, een breede beitel aan een langen steel, o hohonotoko, waarmede men het hout glad makkt, een boor, o gogori, en een klopper, o boboha. Natuurlijk nog een mes voor het snijden der pennen, maar heeft men dat niet, dan gaat het ook wel met het kapmes.

$\mathrm{Om}$ de omgevallen boom uit te meten, moet men een vierdubbel gevouwen touw nemen. Dit moet, want deze maat der prauw, moet gelijk zijn aan het lichaam van den prauwenmaker. Dit betreft namelijk vier verboden, bohono n.l. de hals, de borst en de navel, en de maru-maru, de klossen, zijn de gewrichten. Waar men zich nu echter die andere deelen denkt, weet ik niet. Bij het uitmeten van de boorgaten in de planken, mag men niet meten met de volle vadem of met de volle span, want dat zou aan den prauwenmaker het leven kosten.

Dit zijn nog al duistere bepalingen. Vermoedelijk hebben ze oorspronkelijk wel wat anders geluid, want zoo is er niet veel van te maken. Terwijl men bezig is met boren, mag niemand dichtbij komen, opdat de plank niet splijte. Dit kan zijn omdat dan de geest van den plank schrikken zou, zooals men nu zegt, maar, daar bij het onbeholpen boren, wel de heele aandacht noodig is, is het wel goed, dat de werkman niet door de komst van vreemden wordt afgeleid.

Volgens anderen mag niemand langs de prauw loopen, wanneer 
het breeuwsel, o baru, tusschen de planken gelegd wordt. Ook dit werk moet met veel overleg gebeuren omdat, wanneer het ongelijk verdeeld wordt, de planken niet gelijkmatig op elkaar drukken en de prauw lekken zou. Dat zal wel de reden zijn van dit verbod.

Is de prauw klaar, dan moet de eigenaar er eerst regenwater in doen, vermengd met jonge pinangnoten, en daarmede moet hij de prauw begieten, van binnen en van buiten; ook moet hij daarmede al de gereedschappen afwasschen, die gebruikt zijn; daarna moet hij zichzelf ook met dat water baden, opdat daardoor alle overtredingen tegen den adat, die tijdens het maken begaan zijn, afgewasschen worden.

Volgens anderen moet de nieuwe prauw in zee gesleept en daar gebaad worden, tegelijk met allen, die er aan gewerkt of geholpen hebben.

Ook moet men over de nieuwe prauw een bezwering, een matera uitspreken, opdat hij niet door iemand booswillig bedorven worde.

Volgens sommigen mag de nieuwe prauw niet door dei eigenaar zelf, d. w. z. door den maker, dadelijk gebruikt worden, maar moet die eerst aan verschillende menschen in gebruik gegeven worden, om er overal mee heen te varen, daarna pas mag de eigenaar zelf er gebruik van maken.

Nog zegt men, dat men, alvorens een gekochte prauw te gebruiken of te betalen, aan den maker een mes en een kom moet geven. Doet men dit niet, dan krijgt men ongeluk. Misschien het mes om de verwantschap tusschen den maker en zijn werk door te snijden, maar wat de kom beduiden moet begrijp ik niet.

\section{HOOFDSTUK 27.}

\section{Visschen en jagen.}

In z.ooverre zijn de Tobeloreezen ook grondig van boschbewoners in strandbewoners veranderd, dat $z \mathrm{ij}$ nu veel meer belangstellen in wat in zee zwemt en kruipt, dan in wat op het land loopt of vliegt.

Men kan omtrent een vogel heel wat vragen, eer men den juisten naam weet, heel veel insecten kent men niet bij name; aangaande de kennis van houtsoorten moet men zich geen al 
te hooge voorstelling maken, evenmin omtrent de kennis van namen van planten, maar op zee! Neen maar dan is het verbazingwekkend!

De lui kennen de namen van elk vischje, hoe klein ook, van verre weten zij al aan de eigenaardige bobbeling van het water te onderkennen, welk soort van vischjes daar speelt of dartelt; zij weten den naam van elk schelpdier, klein of groot.

Wat er ook in de zee te zien is, het is voor den Tobelorees geen geheim; hij is op dat gebied met alles bekend.

$\mathrm{Nu}$ leide men hier niet uit af, dat wat de zee betreft met deszelfs inhoud, men natuurstudiëen maakt, want dat is volstrekt het geval niet. De Tobelorees is volstrekt geen bewonderaar van de natuur; ik geloof zelfs niet dat hij daartoe een orgaan heeft. Neen, het is alles gegrond op het utiliteitsbeginsel. Men kent of leert kennen alleen datgene wat nut heeft voor den mensch. Zoo is het ook met wat aan land leeft. De vogelwereld heeft nu eenmaal niet veel nut, dus, voor zooverre die niet uit te vreezen dieren bestaat, heeft men daar niet veel belangstelling voor; van boomen kent men enkele soorten, die men wel eens gebruikt; zoo is het ook met planten en insecten.

En evenzoo is het met de belangstelling voor de zee en deszelfs inhoud en bewoners. Ook hier niet een zucht tot weten, maar alleen belangstelling in wat nuttig is; echter in zee is alles zoowat nuttig. Men onderscheidt visschen, schelpdieren, eliz., in twee soorten ${ }_{1}$ eetbare en oneetbare, en men moet beide soorten kennen, de eetbare om ze te nuttigen en de oneetbare, om zich niet vergissen of te vergiftigen.

Men verwacht de toespijs hoofdzakelijk uit zee.

Natuurlijk jaagt men nog wel, maar door het wonen in vaste dorpen, is de wildstand langzamerhand afgenomen, en dus is men op de zee aangewezen, en daaraan is de groote bekendheid met wat in de zee leeft toe te schrijven.

Om wat in de zee leeft te bemachtigen, heeft men heel wat middelen, die wij achtereenvolgens bespreken zullen.

Het is wel de eenvoudigste methode, om visch en schelpdieren te zoeken op de koraalriffen, die bij laag water droog loopen, ho goaha. Dit zal ook wel de oudste methode zijn.

Er zijn uitgestrekte koraalriffen, en bij laag water, kan men bijna de geheele bevolking bezig vinden allerlei schelpdieren op te rapen en van de koraalsteenen los te hakken, 
Vlak voor de kampongs vindt men niet heel veel, omdat, bij veel varkens de spoeling dun is. Daarom gaat men er ook wel op uit naar meer afgelegen streken, vooral daar waar men breede strandriffen heeft.

De vrouwen hebben een draagmand, o kiarono, op den rug, om het verzamelde er in mede te nemen. Bijna alles is goede buit.

De mannen zijn gewoonlijk gewapend met een vischsteker, een drietand, o hohoba. Dit is een heel eenvoudig instrument. Het bestaat uit drie stukjes ijzer, rond gesmeed, twee met aan de eene zijde een weerhaak, de één, de middenste, met weerhaken aan weerszijden. Ze zijn hoogstens 1 decimeter lang, en worden zoo tegen elkaar aangebonden, dat de weerhaken naar binnen gericht zijn. Men bindt dit vast in een lange dunne bamboe, om aldus visch te kunnen steken, die in de poelen achterblijft welke op de koraalriffen voorkomen.

Ook ziet men dikwijls, dat de mannen aan de uiteinden der riffen, waar de zee die nog een paar voet diep bedekt, staan te hengelen, ho memekana. Men tracht dan met behulp ran een gewone hengel en allerhande aas de grootere visschen te verschalken, die om de koraalrotsen heenzwemmen en zich gaarne verschuilen in de grillig gevormde holen, die diep onder water in de koraalsteenen voorkomen. Een Hollandsche hengelaar zou den dobber missen, want die kent men niet aan het vischtuig. Ook is het juist geen groot genot te noemen, uren lang aldus in de brandende zon te staan, tot den middel of nog dieper in het water.

Een ander soort van dit goaha, is het ho taugumi.

Dit oefent men uit in den tijd dat de voormiddag-eb het laagst is, dat is in die streken in de maanden Mei tot Augustus. Het woord beteekent: touwtrekken, en dat is het inderdaad ook. Men zoekt bij elkaar veel lianen, o gumini, die men aan elkaar hecht, waardoor men soms een touw verkrijgt van eenige honderden meters lengte. Het mag geen ander soort touw zijn, want dat voldoet niet aan den eisch, aangezien het moet drijven. Men gaat nu met veel menschen tezamen, hoe meer hoe liever, gewoonlijk een heele kampong, ook wel twee kampongs tezamen, met heel wat prauwen, naar een der groote, midden in zee gelegen koraalriffen. Men zorgt daar aan te komen, eenige uren voor het water op zijn laagst is; men legt het touw nu aldus 
uit, heel voorzichtig handelende, dat het om het rif heen, een groote ring op het water vormt. Nu vaart men met de prauwen zoo, dat men het rif ongeveer omsingelt, waarna allen, zoo veel mogelijk tegelijk, in het water springen en op afstanden het touw aanvatten, dit een heel eind onder water duwen, en nu beginnen, dit gelijkmatig heen en weer te rukken. Soms staat het water nog zoo hoog, dat de kleinsten moeten zwemmen, terwijl de langsten al kunnen staan op de kanten van het rif. Men gaat nu gestadig voort met het touw heen en weer te rukken, onder den kreet: naro' naro' ‘trekken, trekken, (deze woorden zijn Ternataansch. Of men die taal ook verder bezigt bij dit werk, weet ik niet, maar ik geloof het niet).

En zoo trekt men het touw heen en weer tot het water valt, steeds lager, zoolang, dat de rand van het rif droog ligt en de visch niet meer naar volle zee kan ontsnappen.

Hoe genoeglijk het moet zijn, aldus eenige uren in de brandende zon door te brengen, kan men zich wel denken, maar toch zien de menschen daar nooit tegen op, en schijnen het zelfs heel aangenaam te vinden. Dat vrouwen, mannen, jongelingen en jongedochters te zamen gaan, zal er wel toe bijdragen om het aangenaam te maken.

De bedoeling van dit zonderlinge doen is, de boven het rif zwemmende visch te beletten, naar open zee terug te keeren. Daarom moet het touw onder water steeds in beweging blijven, om op die manier een soort tooverring te maken, waar de visch niet overheen durft.

Heeft het rif geen natuurlijke rand, dan maakt men die er omheen van opgezette steenen, o kota, want die rand is noodig natuurlijk.

Zoodra het water zoover afgeloopen is, dat de visch niet meer kan ontkomen, gaat men met zijn allen op de buit los. Hier en daar vindt men de visch in kleine plasjes, ook wel op de steenen droog liggende, maar het meest heeft die zich teruggetrokken in de diepere kuilen, waaruit men ze nu dus nog weer moet zien te bemachtigen. Gewoonlijkt bedwelmt men ze dan, om ze gemakkelijker te krijgen. Het is nu een drukte van je welste, want er heeft geen redelijke verdeeling van den buit plaats, maar elk heeft slechts dat, wat hij zelf weet te bemachtigen. Men neemt dan ook gewoonlijk het heele gezin mede, ook de kleine kinderen, want elk paar kleine 
handjes grijpt toch licht wat. Dat vechtpartijen enz. hierbij niet uitgesloten zijn, is wel te denken, hoewel dat toch zelden zoo'n vaart neemt, dat men voortaan niet meer wil samenwerken.

De visch op deze manier bemachtigd, is ook nog koraalvisch, diepwatervisch krijgt men natuurlijk niet, want die houdt zich nooit boven de riffen op. De buit is heel verschillend. Het kan mee en tegen vallen, dat spreekt.

Het is een allerkluchtigst gezicht, wanneer men van een afstand dit tooneel ziet. Men ziet in den beginne niets dan koppen boven de zee uitsteken, en langzamerhand ziet men. daar de lichamen aangroeien, zoodat het dan uit de verte het aanzien krijgt, alsof er een levend hekwerk in zee drijft.

In de tegenovergestelde maanden van het jaar, dus wanneer de namiddageb het grootst is, in de maanden December tot Maart, gaat men des avonds met flambouwen, gewoonlijk van drooge bamboe gemaakt, o hilo of o loba, bij laag water op het strand visschen, swaar dan allerlei soort van visch in het zakkende water speelt. Men wandelt door het water, in de eene hand de flambouw, in de andere de drietand, of, bij vrouwen, gewoonlijk een kapmes, om op die wijze de visch die op het licht aankomt, en daardoor gefascineerd wordt, te bemachtigen.

Ook dit doet men nog al gaarne, hoewel hierbij meer ongelukken voorkomen, daar men niet goed zien kan, waar men zijn voeten zet, en daardoor nogal eens de voeten verwondt, óf door in scherpe schelpen te trappen, of door wat veel erger is, op de rugvin van een soort giftige visch de voeten te zetten. Dit wordt dadelijk gevolgd door een hevige pijn. Wel gaat die pijn nogal gauw over, maar dan ontstaat er een leelijke wond, waarbij heel snel koud vuur optreedt, zoodat soms in een paar dagen tijds een ongelooflijk groote rottende wond ontstaat, die meer dan eens den dood tengevolge heeft. Deze visch is op zich zelf niet giftig, met eet hem zelfs gaarne, het is alleen maar een verwonding door de rugvin, die zulke vreeselijke gevolgen heeft, en daar het dier de gewoonte heeft, zich in het zand te graven, komt het zelfs voor, dat bij daglicht nog menschen hierdoor getroffen worden, hoeveel te meer des nachts.

Men is dan blootgesteld aan nog meer gevaren: Een soort geep, met verbazend langen scherpen bek, verwondt ook dikwerf de beenen der visschers. Ik heb eens een geval gezien, 
waarbij het dier, zijn met weerhaken voorzienen bek, dicht boven de hiel, tusschen de achillespees en het kuitbeen geboord had. Daar was hij afgebroken, en verwijdering was zoo goed als onmogelijk.

Niettegenstaande dit alles, gaat men er toch ook wel gaarne des nachts op uit. Vooral allerlei soort poliepen, vangt men op deze wijze. Ook heeft men op sommige plaatsen gelegenheid visch te bemachtigen, die zich ophoudt in monden van rivieren, of in poelen, die door de rivieren gevormd worden, wanneer de mond aan zee dichtgeslagen wordt met zand, ook wel in sommige bochten, die de zee vormt, met smalle uitgangen. Men verzamelt zich ook daartoe, soms uit den geheelen omtrek, maakt de poel of den riviermond open, en laat het water langzaam afvloeien, waarbij men kleine zeefjes tegen het water in houdt, om de met het water afvloeiende visschen, op te vangen. Is zoo'n poel of plas bijna leeggeloopen, dan wordt de visch bedwelmd, ho hurutu, en men bemachtigd die dan gemakkelijk.

Natuurlijk is het juist geen lekkere visch, die men uit dergelijke poelen krijgt, maar kieskeurig is men op dat punt niet.

Dat soort visscherij noemt men ho honga, welken naam men er ook aan geeft, wanneer men verder landwaarts in, de rivieren opgaat, om aldus visch te bemachtigen, in den droogen tijd vooral paling, die dan zich verzamelt in kuilen, die de rivieren hier en daar maken.

Wij spraken reeds van visch bedwelmen, ho hurutu, ook wel ho ludja genoemd, naar gelang van de wortels die men daarvoor gebruikt.

De wortels van verschillende planten hebben de eigenschap, giftig te zijn voor visch. De dieren sterven wel niet er door, maar toch komt de visch bovendrijven, en ik geloof niet, dat visch, eenmaal vergiftigd, weer opleeft. Natuurlijk is dat nu niet erg wanneer men het doet in een poel, of wel in de kuilen, die in de koraalriffen zijn, waarin de visch achterblijft. Het gaat dan zelfs heel gemakkelijk. De, op een bosje gebonden wortels, worden geklopt, zoodat het sap er uitvloeit, en men steekt die dan in het water, met een langen stok tot op den bodem doordringende. Doet men dat eenige malen, dan drijft de visch al naar boven, zoodat men die zonder moeite op kan scheppen.

De visch wordt er niet oneetbaar door, ook bederft de smaak 
niet, hoewel sommigen beweren, dat vergiftigde visch, indien men die wil droogen of rooken niet duurzaam is.

Heel wat erger is het evenwel, dat velen maar uit gemakzucht, hier en daar in open zee, met dit vergift aan het werk gaan; en het aan een lijn doen zakken, zoo diep mogelijk, waarna zij het op dezelfde hoogte houden en door het water voortsleepen. Het is er hierbij om te doen, dat enkele grootere vischen vergiftigd zullen worden, en zullen komen boven drijven, zooals ook soms gebeurt. Echter is het duidelijk dat door deze handeling de vischstand zwaar beschadigd moet worden, want in het open water wordt heel wat visch gedood, die wegdrijft, en nutteloos te gronde gaat. Het vergiftigen is dan ook verboden, maar in den regel geldt het verbod juist dan, als hoegenaamd geen schade aangericht wordt, nl. bij het gebruik van het vergif in riviermonden of kuilen, terwijl degene die heel kalm in volle zee visch vergiftigt, vrij uitgaat, daar er geen getuigen zijn van deze overtreding.

Men vischt met de lijn op verschillende manieren.

Van het strand af, op een manier, die men ha totango noemt. Bij laag water, slaat men zoo ver mogelijk in zee, twee palen, boven door een dwarslat verbonden. Men hangt nu bij hoog water de lijn over die dwarslat heen in zee, terwijl de visscher aan het strand staat. Het doel is natuurlijk, dat op deze wijze in betrekkelijk diep water gevischt kan worden zonder een prauw te gebruiken.

Ook vischt men van een prauw uit wel op dèze manier, dat men een lichte lijn gebruikt, waaraan men op zekere hoogte, een groot boomblad bevestigt bij wijze van vlieger. Men slingert nu de lijn met de haak weg, en laat dan het blad opgaan, dat de lijn overeind haalt. Het andere einde van de lijn, blijft in de prauw. Men hengelt aldus naar visschen, die dicht aan de oppervlakte van het water in open zee zwemmen.

Dit zijn echter maar een soort spelletjes, tegenover het eigenlijke met de lijn visschen in diep water. ha la ungu.

De lijn die gebruikt wordt, heet o njimo. Men kan die natuurlijk in de toko's koopen, maar toch is het veelal gewoonte, dat men die zelf vervaardigt. Vroeger moet men dat gedaan hebben van de vezelbast van een soort boom, o rukiti, maar dat heb ik nooit meer zien doen.

Men bezigt een soort garen, dat men koopt bij de handelaren, 
onder den naam be nang costa. Het is zeer dun, nogal onsterk garen, dat in groote strengen verkocht wordt. Men windt dat eerst op, met een soort machine, die men zelf maakt, o d ja tera, waarna het getweernd wordt. Men maakt daartoe een soort lijnbaan, heel lang, aan weerszijden tusschen twee palen een dwarslat, de ééne voorzien van pennen. Men scheert nu het fijne garen hier langs, zoovele malen als men het in elkaar wil draaien, hangt aan de eene zijde een eenigszins zwaar voorwerp, dat men in een draaiende beweging brengt en daar men verscheidene naast elkaar spant, en dus tegelijk aan het draaien kan houden, gaat dit nog al gauw.

Heeft men eenmaal op die wijze steviger touw verkregen, dan draait men dat weer in elkaar, naar gelang van de dikte die de $n$ jimo hebben moet. De lengte is heel verschillend. Men rekent die altijd bij vademen, en wel bij tien vademen gelijk, o tarantu geheeten. Men maakt de lijn steeds zonder aanhechting, al is die ook nog zoo lang, soms meerdere honderden vademen.

Alvorens ze te gebruiken, worden ze getaand, met het bastaftreksel van een boom, o hamehe geheeten, daar anders het zeewater te spoedig de lijn zou vernielen. Want men begrijpt, dat een lange sterke lijn, voor een Tobelorees een heele schat vertegenwoordigt.

Voor het visschen dicht onder de kust heeft men zulke lange lijnen niet noodig, maar energieke visschers varen gaarne ver in zee naar daar liggende ondiepten, om in de nabijheid daarvan te visschen. Natuurlijk kan dat alleen bij niet al te onstuimige zee. Men vangt daar groote visschen.

Aan de lijn wordt een haak bevestigd, o guma, die men zich dikwerf ook zelf smeedt, van sterk koperdraad.

Als aas gebruikt men wel kleine vischjes, maar meer nog de halsveeren van een haan, aan een klein bosje bij elkaar gebonden.

Om als zinklood te dienen, gebruikt men een meer of minder zwaren steen, die men met een blaadje van een arenpalm boven den haak bevestigt. Daarboven een rond stukje bamboe, o dj a di. Men laat nu de lijn zakken, totdat men grond voelt, om dan het biesje, waarmede de steen vastgebonden is, los te rukken, waarna het heen en weer halen van de lijn aanvangt, tot men voelt dat de visch bijt. Is de visch bijzonder groot, hetgeen de ervaren visscher voelt, dan laat men wel langs de lijn een met 
tabak omwoelden ring zakken, opdat deze op den neus van den visch komt, en deze bedwelmt, teneinde de visch op die wijs gemakkelijker binnen boord te brengen. Om zich des nachts bij het visschen de slaap uit de oogen te houden, roept men elkaar toe, zingt, jodelt, enz.

Een bijzonder soort visscherij of hengelarij heeft men nog naar de ido, in het Maleisch tjakalang geheeten, een groote visch, die veel langs de kust in de Kaubaai voorkomt. Deze zwemt met groote scholen. Men heeft voor deze visscherij breede, platte prauwen, zonder uitleggers. In den bodem zijn een aantal gaten geboord, met proppen voorzien natuurlijk. Bij de prat:w behooren een aantal sterke hengels. Men heeft noodig een niet om aasvischjes te vangen, o hom a. Vele visschers moeten hierbij samenwerken want minstens een man of tien of meer moeten de prauw bemannen, daar die een snelle vaart moet kunnen hebben.

Men vaart des morgens uit, en tracht eerst door eenige trekken met het net langs de kust, kleine aasvischjes te vangen. Vangt men die, dan laat men het water door de gaten in de prauw stroomen, opdat de vischjes in het leven blijven. Een paar menschen worden aan het werk gezet, om het water weer uit te scheppen, waarbij men dat door zeefjes, o dafi, laat loopen om de vischjes niet mee in zee te scheppen.

Men gaat nu naar de open zee op zoek naar de ido, die door boven het water uit te springen, de plaats waar zij zich ophoudt spoedig verraadt. Men roeit met korte scheppers en zeer snelle slagen, Ziet men een school, dan vaart men er op los, om, in de buurt gekomen, voorzichtig te naderen en door het uitgooien der aasvischjes de visch te lokken. Gelukt dit, dan werpen een paar menschen steeds vischjes onder de groote visschen, en anderen beginnen met de hengels de visschen op te slaan. Men laat zich ook nog wel door andere prauwen vergezellen, die aan den buitenkant van de school visschen. Soms gelukt het op deze wijze in één keer de prauw vol met groote visschen te vangen. De gaten in de prauw moeten dan dicht gestopt worden, en naardat de visch aan boord komt, moet het water natuurlijk worden uitgeschept. Gaat de vangst voordeelig, dan is dit een prachtige methode. De gevangen visch wordt naar een vaste regeling, tusschen de opvarenden, de eigenaar van de prauw, van het net en het hengeltuig verdeeld, zoodat daaruit zelden twist ontstaat. 
Men kent ook het in Indië overal gebruikelijke werpnet, Maleisch djala, hier o dja geheeten, waarmede men vooral kleinere soorten visch vangt, die op sommige tijden van het jaar dicht onder de kust komen, vooral een soort sardine, o makehe geheeten.

Waaraan het ligt, weet ik niet, maar deze visch heeft dikwerf bedwelmende eigenschappen. Ik meende vroeger, dat dit wellicht was, zooals men mij mededeelde, dat n.l. de visch op zichzelf de eigenschap niet had, maar dat hij, door zijn oppervlakkig zwemmen, giftige stoffen van het zeeoppervlak inslikte. Het zat dan dus alleen maar in de ingewanden. Maakte men ze goed schoon, dan was ze altijd goed. Het is hiermede n.l. wel wat treurig gesteld. Men eet kleinere visch wel rauw, met huid en haar, alleen met wat azijn of citroensap b.v. ho ma go, versch opeten:

Echter, ik heb ook vergiftigingsverschijnselen gezien, ontstaan na het gebruik van gedroogde vischjes, die heel goed schoongemaakt waren. Het giftige moet dus in deze visschen zelf zitten, en komt veel voor. Bij lichte graad van vergiftiging voelt men zich duizelig, bij ernstige gevallen valt men in een slaap, onrustig en ijlend, die zelfs in den dood overgaat. Ook ontstaan allerlei krampen en zinsbegoochelingen.

Zelf woonde ik b.v. bij, dat een Goeroe, die des morgens twee gedroogde vischjes gegeten had, ongeveer een uur daarna zulke hevige krampen kreeg, dat men voor zijn leven vreesde. Ik werd gehaald, maar toen ik den patient zag, was het gift al een uur of wat geleden ingenomen, en de man al iets beterende. Het duurde echter meer dan een week, eer de man normaal was. In een ander geval bezocht ik een ongehuwde Goeroe. $Z_{\text {ijn }}$ gemeente had hem al in twee dagen niet gezien, en meende dat hij bij ons vertoefde. Ik ging het huis binnen, en vond hem wezenloos op een stoel zitten. Toen ik hem aansprak, sloeg hij allerlei wartaal uit. In zijn keuken vond ik nog overblijfselen van een maaltijd van rauwe vischjes. Bij onderzoek bleek, dat hij met een zijner gemeenteleden twee nachten geleden was gaan visschen. Thuis gekomen, had hij van de vangst dadelijk klaar gemaakt, en sinds had men hem niet meer gezien. Ik liet den man naar ons huis brengen, waar hij tegen den middag aankwam. Hij ging toen liggen, viel spoedig in slaap, en sliep zoowat 24 uren aan een stuk. Daarna ontwaakte hij, maar kon 
zich van de dagen, verloopen sinds hij de visch gebruikt had, niets meer herinneren. Hij was na het eten der vischjes gaan slapen, en wakker geworden, verwonderd over de vreemde omgeving.

Echter, hoewel deze eigenschap heel goed bekend is, en heel velen bedwelmd worden, soms een heele kampong tegelijk, g at men toch rustig voort de vischjes te vangen en te eten.

Maar het echt Tobeloreesche werpnet is niet de $\mathrm{dja}$ maar de o wakomomu. Dit is een werktuig, bestaande uit ruim een meter lange, sterke buigzame latjes, gewoonlijk de dikkere vezels uit het haarnet van den arenpalm, die men van boven bij elkaar gebonden heeft. Een eindje naar beneden, heeft men binnen in, een rotanring bevestigd, waardoor het geheel het voorkomen krijgt van een vat. Met dit werktuig nu, klimt men op een over het water hangenden boom, om vandaar uit de vischjes te bespieden, die daaronder zwemmen. Meent men, dat die genoegzaam talrijk zijn, dan springt men, met het net in de hand, naar beneden. Zoodra dit den waterdruk ondervindt, buigt het open, en spreidt zich nu plat op den bodem, de vischjes er onder drukkende, vastgehouden door het gewicht van den visscher, die boven op zijn net valt, want hij springt er immers zelf mee naar beneden. Hij probeert nu, na opgestaan te zijn, door den kop van het net om te draaien, de latjes dichter bij elkaar te brengen, en die in het midden naar boven te trekken, de ondereinden stijf over den bodem krabbende.

In een gelukkig geval, krijgt men op deze wijze wat visch, maar natuurlijk nooit zooveel als met een gewoon werpnet. In een ongelukkig geval, breekt de visscher arm of been. Want men bedenke, dat de man zich soms van een aanzienlijke hoogte naar beneden laat vallen. Ongelukken komen dan ook herhaaldelijk voor, maar toch blijft de Tobelorees zijn wa k o m o m u gebruiken, hoewel het wel het onbeholpenste vischtuig is, dat ik ken.

Een soort haring, o ngowaro, in het Maleisch ikan djoelo eng geheeten, komt ook in groote scholen onder den wal, om kuit te schieten, naar het schijnt. Zoo mogelijk vangt men die ook wel met dja of wakomomu, maar meer toch tracht men dat te doen, door des nachts tusschen een school te varen. Men siaat dan midden daarin met een werktuig, bestaande uit een soort korf met een hengsel, waaraan een sterk touw, waarmede de korf bevestigd is aan een stevige bamboestok. O djako heet 
dit werktuig. Hoewel ook dit een tamelijk onbeholpen visscherij is, vangt men daarmede toch soms groote hoeveelheden van deze visch.

Men vangt deze haring ook met groote treknetten, o gio pu, waarbij soms zooveel tegelijk gevangen wordt, dat men de visch niet behandelen kan. Deze visch wordt namelijk ter conserveering gerookt.

De echt tobeloreesche manier is, dat men van twee visschen, door ze met den bek door elkanders staart te steken, een ring maakt. Die ringen legt men schuins over elkaar op een bamboelat. Heeft men op deze wijze een dertig visschen neergelegd, dan wordt de bamboelat omgebogen, en de einden met een bandje aan elkaar bevestigd; o waja heet men dat.

Men weet op deze wijze de visch tamelijk snel te bewerken. Wordt ze spoedig na het vangen boven het vuur gerookt, dan is ze tamelijk duurzaam en blijft zelfs zes tot acht maanden goed. Is echter de visch al iets bedorven, vòò ze boven het vuur komt, dan wordt ze door het rooken nog wel weder goed, maar is niet duurzaam. Om een goed resultaat te verkrijgen, moet het rooken heel lang voortgezet worden. Zouten doet men de visch helaas niet, zoodat ze voor Europeeschen smaak niet genietbaar is. Maar ook in dezen stelt een Tobelorees niet veel eischen.

De ido wordt ook gerookt, tusschen bamboelatjes geklemd, maar in tweeën gespleten, waarbij men de ruggegraat er uitsnijdt. Ook deze blijft eenige maanden goed, hoewel niet zoo làng als de haring.

Andere vischsoorten verduurzaamt men niet, omdat men die zelden in groote hoeveelheden vangt, waardoor het verduurzamen de moeite loonen zou. Wat anders is het, indien men bepaaldelijk er op uit gaat naar andere streken, om zich door de vischvangst geld te verschaffen. Men doet dat nooit in eigen land, omdat men er dan niet toe komt de visch te conserveeren, aangezien men te veel aan vrienden en geburen weg moet geven. Men vischt dan op allerlei wijze, ook vooral met de lijn, en men droogt de visch, na ze in zeewater eenigermate gezouten te hebben. Men splijt ze daartoe open, en maakt ze zoo dun mogelijk, om ze gemakkelijker te drogen. Die gedroogde visch, o bakaha, is nog al tamelijk duurzaam. Men tracht gewoonlijk die te verkoopen aan handelaren in de buurt, of wel op de hoofdplaats Ternate. 
De Kausche Tobelo's kennen nog het visschen naar een eigenaardig soort kleine vischjes, die daar diep in de baai, soms onder de kust komen, o kubo-kubo geheeten, in het Maleisch ikan ngafi.

Deze diertjes worden op zijn hoogst vijf à zes centimeter lang, en komen in ontzettend groote scholen onder de kust. Men vangt ze dan met een soort netten, dicht geweven van kofovezel, o k of o geheeten, waarin men ze gewoon trekt. Ze worden ook versch gegeten natuurlijk, maar het grootste gedeelte wordt op bamboehorden gedroogd, en zoo in den handel gebracht.

$O$ wee, de neus van een argeloozen vreemdeling, die Kau komt bezoeken in dezen tijd, vooral, als na een paar regenachtige dagen de zon doorbreekt, want de stank die dan de massa horden verspreidt, is onbeschrijfelijk. Het gedroogde product is dan ook niet welriekend, maar bij gebrek aan versche visch eet men het toch gaarne.

Ook vangt men langs deze kust, een soort fijne garnaaltjes, o hia-hia, die eveneens gedroogd in den handel gebracht worden. Men bezigt hiertoe een soort schepnetten. Ook van dit product zal een Europeaan niet beweren dat het lekker is, zelfs de Tobelorees uit Tobelo eet het niet dan in hoogsten nood, maar de Kausche Tobelorees vindt het wel lekker. Het is voor hem dan ook een vrucht van eigen bodem. (Mijn vrouw deelt mij echter mede, dat ik me vergis, daar ik zelf meermalen die garnaaltjes bij de rijsttafel gegeten heb, in allerlei sambalans. Alle Europeesche dames op Ternate gebruiken die; ze zijn heel goed, maar de inlanders weten ze niet klaar te maken, zegt mijn vrouw).

Een onderdeel van de vischvangst is ook de jacht op schildpadden, o hene, waarvan men twee soorten kent: o wuhi, de schildpad met het waardevolle deksel, en o tapa, de visch-schildpad.

Men komt wel eens hier en daar een exemplaar tegen, dat men dan natuurlijk tracht te bemachtigen, met allerlei wat men bij de hand heeft, maar voor de eigenlijke jacht rust men zich behoorlijk uit.

De prauw wordt vóór ingericht om de lijn te bergen, die aan de harpoen bevestigd is, en voorzien met een toestel waarover men de lijn kan uit vieren. Men gaat op sommige tijden van het jaar naar smalle zeestraten, waar men weet dat de dieren langs trekken. 
De harpoenier moet natuurlijk iemand zijn, die uitstekend met de lans weet te werpen.

Gewoonlijk gaat men met zijn drieën, twee visschers' en de harpoenier.

De harpoen, een scherp ijzer met een sterken weerhaak, ma kobe, is aan de schacht, ma mai, los verbonden. Aan de harpoen zit de lijn, een lang sterk touw. Heeft men geworpen en het dier is vastgeraakt, maar laat zich zeer diep zakken, dan heeft men een scherpe lans, bevestigd aan een lange bamboeschacht met zand gevuld zoodat die gemakkelijk zinkt, o gogurumini, waarmede men het dier onder water afmaakt, en dan voorzichtig in de prauw brengt.

Het gewin is soms heel aanzienlijk. Helaas komen nog al eens vergiftigingsgevallen met het vleesch voor. Het schijnt niet gemakkelijk uit te maken of het eetbaar is. Om het te weten te komen, legt men wel een stuk van het vleesch dicht bij een nest met roode mieren. Eten de mieren het vleesch, dan is het goed, maar blijven die er verre van, dan is het slecht, bepaaldelijk giftig.

Het schijnt, dat op de eilanden Mojau en Tafoere schildpadden eieren leggen, want daar gaat men gewoonlijk heen, om eieren te halen, en de dieren bij het eierleggen te vangen, maar in het Tobelosche is mij nergens een eiland bekend, waar de dieren aldus gevangen kunnen worden.

Ook zoekt men tripang (holoturnia sp:) o taudja, hoewel men die zelf niet eet. Ziet men ze, dan neemt men ze altijd mee, om ze te droogen voor verkoop aan de Chineesche handelaren.

Gaat men er expres voor uit, dan gaat men naar plaatsen, waar een tien tot twintig meter water staat, zoodat men op den bodem de dieren onderscheiden kan. Daarvoor moet men dan natuurlijk Tobeloreesche oogen hebben, want ik zag zelden iets in die diepe schemering. Is het water niet heel diep, dan gebruikt men een met zand gevulde bamboe, aan welks eind men een aantal pijltjes in ringvorm bevestigd heeft, om het dier te steken. Is het water nog dieper, dan bevestigt men dit ronde instrument, aan een zware, maar korte, met zand gevulde koker, die men aan een lijn laat zakken, om aldus het dier machtig te worden.

Het spreekt wel vanzelf, dat niet iedereen schildpadden jaagt, of er zijn werk van makkt tripang te visschen.

D1. 78. 
Wat nog wel vermelding verdient, is het duiken der Tobeloreezen. Daarin hebben sommigen (niet allen) het tot een verbazende vaardigheid gebracht. Er zijn er die 20 à 25 meter diep duiken. Het wordt al van jongs af beoefend. De kinderen zijn echte waterratten, die zwemmen en duiken als eenden. Maar ook het duiken heeft natuurlijk een zeer praktischen kant, want men brengt duikende allerlei schelpen boven. Men gaat er zelfs expres voor naar de eilanden Mojau en Tafoere, om daar de z.g. bia boela n te duiken. Met heele vloten trekt men daarheen om dan bij terugkeer de schelpen bij de handelaren te gelde te maken. Ook dichter in de buurt duikt men wel, hoewel daar die schelpen niet voorkomen, maar toch wel andere soorten, die ook handelswaarde hebben.

De meest winstgevende duikerij is wel de parelduikerij, diep in de Kaubaai. Het spreekt vanzelf, dat concessionarissen de parelbanken afduiken met behoorlijke duikertoestellen, maar de Kausche Tobelo's weten toch ook wel hun slag te slaan. Tot op zekeren afstand van de kust is het duiken hun toegestaen, en soms worden zeer waardevolle parelen door hen gevonden. In de kuststreek waar men het meeste duikt, is ook tengevolge hiervan nog al welvaart, hoewel die, vroeger tenminste niet heel zichtbaar was. Men bleef in kleeding, huisbouw en zoo, volkomen dezelfde, ook al was men kapitalist, Alleen was het merkbaar aan de vreeslijk hooge bruidschatten, die men daar vroeger betaalde, en helaas ook wel aan de onzedelijke leefwijze, dat er veel geld in de streek zat.

Tobeloreezen van andere streken komen hier niet duiken, uitsluitend de bewoners van de streek zelve. Ten eerste weten die alleen waar de meest waardevolle banken liggen, en ook zouden zij het anderen niet toestaan de winst met hen te deelen.

Ook is nog onder vischvangst te rekenen, het scheppen van de pariama, de wormen die eens per jaar uit de koraalsteenen in zee kruipen. Men vind die speciaal langs de kust, waar men maar poreuze koraalsteen aantreft. Dit zijn draaddunne wormen, eenige centimeters lang, bestaande uit de geslachtsrijpe deelen van een wormsoort die in de koraalsteenen huist, die op bepaalde tijien afgestooten worden.

Het heeft feitelijk driemaal per jaar plaats, maar alleen de voorlaatste maal is het de moeite waard.

Men weet die nacht uit den stand van het zevengesternte 
met de maan heel goed te berekenen en vergist zich daarin hoogst zelden.

Men maakt tevoren allerlei schepnetjes klaar, om daarmede de dieren uit zee op te scheppen. Zij vloeien des nachts uit, en des morgens verdwijnen ze. Ik meen opgemerkt te hebben, dat ze wegzonken, hoewel men zegt dat ze door de zonnewarmte smelten. Het aldus uit zee opgeschepte, is een griezelige vette massa, die men echter heel gaarne eet.

Men bereidt ze op allerlei manieren, meest met zeer sterk riekende specerijen, en eet ze dan met sagoe, rijst enz.

Ook verduurzaamt men ze wel door ze in platte bladerenbakjes te doen en ze dan zachtjesaan te rooken, tot ze een soort platte koekjes vormen.

Jong en oud neemt aan die schepperij deel, vooral jong, omdat het in den nacht gebeurt, hetgeen natuurlijk aan de zedelijkheid niet ten goede komt.

Dat ook de visscherij wel zijn eeredienst heeft, is van zelf sprekend, hoewel lang zooveel niet als de landbouw. Dat is natuurlijk, omdat de landbouw veel ouder is dan de visscherij. Men heeft eerst leeren visschen toen men aan zee kwam, maar het is wel te denken, dat het nieuwe niet meer zoo sterk in den cultus opgenomen werd als het oude.

Toch is het algemeen animistische natuurlijk ook op de visscherij van toepassing. Ik hoorde eens, dat een oude heer opgespeeld had tegen lichtzinnige jongelui, die bezig waren steenen in de prauw te doen, om ze te gebruiken bij het visschen met de lijn. Het kwam hierop neer, dat het jonge geslacht wel knap was in het opzoeken van steenen, maar dat ze toch niet veel geluk hadden bij het visschen, omdat ze vergaten, bij het neerdalen van de lijn te vragen: gomanga ni hi riwo, geesten help ons, zooals dat vroeger algemeen gebruikelijk was.

Volgens sommigen moet men, alvorens te gaan visschen met de hengel of de lijn, die gereedschappen eerst begieten met bepreveld water, anders heeft men geen geluk. Gaat men er op uit om visch te steken met den drietand, o hohoba, hetgeen men ook veel doet onder scholen visch, die aan de oppervlakte van het water rondspelen, of die altijd aan de oppervlakte zwemmen, zooals rog en dergelijke, dan moet men de hohoba met bepreveld water besprenkelen, opdat hij goed rake, en de handen met dat water wasschen, opdat zij vlug zijn bij het werpen. 
Bij het tjakalang, o ido, visschen, moet de man die de aasvischjes uitstrooit, er eerst een in zijn mond nemen en opeten, onder het uitspreken der woorden: ika, olomo: vooruit, eet! Dit zal wel een soort sympathiemiddel zijn, opdat de visch even gulzig happe als hij zelf.

In het Dodingasche binden sommigen een kop of een klauw van den kleinen vischarend, o pole pole, Ternataansch: goheba, aan de prauw, wellicht om zich daardoor iets toe te eigenen van het scherpe oog, dat deze arend voor de visch heeft.

Een voorschrift zegt: terwijl de man op zee is om te visschen, mag de vrouw heur haar niet kammen, of geen vuil opvegen, opdat niet de visch van den hengel valle, of het vischtuig bederve. Dat is natuurlijk ook een sympatiemiddel, hoewel het verband tusschen den man op zee, en de vrouw haar haren in huis, wel niet gemakkelijk aan te wijzen is.

Dat men aan netten en aan grooter vischtuig evenals aan de prauw een geest toekent, een gikiri, die men te vriend moet houden door een offer, hebben wij reeds vroeger opgemerkt.

Bij het schildpadvisschen mag de lijn nooit anders dan vóbr in de prauw bewaard worden, anders zal hij niet raken. De man aan het roer mag niet opstaan, ook niet, als de schildpad reeds gevangen is. Dit kan ook wel een voorzichtigheidsbepaling zijn, dunkt me. De prauw moet steeds zoo stil mogelijk gehouden worden.

Heeft men een schildpad gekookt, dan mag men tijdens den maaltijd geen leven maken, ook elkaar niet met de afgekloven beenderen gooien, of die wegwerpen, maar men moet die heel stilletjes op een hoopje bij elkaar leggen, anders heeft men in het vervolg geen geluk meer op de jacht.

Het is mogelijk, dat de laatste bepaling een animistischen inhoud heeft, maar het kunnen ook allemaal wel bepalingen zijn om te voorkomen, dat men door luidruchtig optreden, de schuwe dieren verjagen zou.

$\mathrm{Bij}$ de parelvisscherij heeft men ook nog bijgeloof. Op zekeren keer werd afgekondigd, dat gedurende zekeren tijd niemand duiken mocht, aangezien men voor den Sultan van Ternate moest duiken.

Den dag, voorafgaande aan dien, waarop dat duiken voor den Vorst zou plaats hebben, voeren de Ternataansche Hoofden, onder groot hallo, met een groote prauw tusschen de parel- 
banken door, onderweg steeds met kurkuma gekookte rijst in het water strooiende, onder allerlei beprevelingen. Men had eerst een feest gevierd voor den parelgeest, en nu was dit het offer dat men uitstrooide, om dien geest gunstig te stemmen.

Er zijn nog wel jagers onder de Tobeloreezen, maar over het geheel heeft hij zich zoover bij den nieuwen toestand van strandbewoner te zijn, aangepast, dat hij nu meer visscher is dan jager. Visschen doen allen, jagen enkelen.

Men jaagt herten en varkens. Andere dieren, die de moeite waard zijn om ze te eten, levert het land niet veel op.

Wel is waar eet een enkele nog leguanen, maar dat is een overblijfsel van vroeger, uit den tijd dat men nog geen visch had.

De boschbewoners eten n.l. dat dier geregeld, zooals die ook wel kikvorschen eten, maar de strand-Tobelorees voedt zich over het geheel niet meer met dergelijke dieren. Hij eet visch en wat de zee oplevert, en al vindt hij herten- en varkensvleesch ook lang niet te versmaden, het is toch geen hoofdvoedsel meer voor hem.

Vroeger heeft men veel herten gejaagd om er gedroogd hertenvleesch, dengdeng van te maken, dat toen een zeer gewild handelsartikel was, aangezien het een vast bestanddeel is van de Europeesche rijsttafel. Nu echter is dat heel wat veranderd, misschien ook wel doordien velen meer damarhalers geworden zijn sinds de damar een gewild handelsartikel werd.

Hoewel men de oude wapenen voor de jacht volstrekt niet versmaadde, had men toch al heel wat geweren waarmede men rijn buit wist te bemachtigen. Dat men nu juist goed schiet met die geweren, kan ik niet beweren. Ik heb nooit iemand ontmoet, die in Europeeschen zin, een goed schutter was. Dat is nu ook volstrekt niet te verwonderen, omdat de oefening ontbreekt. Het buskruit was duur, eveneens de andere ammunitie, en dikwerf heel moeilijk te verkrijgen. Van schieten voor oefening is dus nooit sprake, en waar vandaan zou dan bij de enkele maal dat men schiet, een geoefend oog en een vaste hand komen?

Bovendien, dat is ook niet zoo heel noodig bij het Tobeloreesche jagen. Een dier in den snellen loop of in de vlucht te schieten, komt niemand in den zin. Men heeft al den tijd, en speurt eerst naar den weg, waarlangs het hert of het varken komt, wacht heel geduldig af tot het dier daar langs komt, en 
schiet dan niet, voor het vlak bij is. Of wel, men klimt in een boom langs den weg dien het wild gewoonlijk neemt, en wacht nu heel kalm af, tot het dier onder den boom langs komt. Bij heel weinig geoefendheid, kan men op die manier nog wel wat raken.

Men houdt ook wel gezamenlijk drijfjachten, genoemd ho $\mathrm{kau}-\mathrm{kau}$, naar het geschreeuw dat men daarbij aanheft. Ook dan klimmen de schutters in boomen, hetgeen altijd het voordeel geeft, dat de kogel niet horizontaal vliegt, en dus niet gau!: ongelukken aanricht. Hoewel dan het wild onder de schutters doorgejaagd wordr, is het resultaat gewoonlijk heel gering, ook al door diezelfde ongeoefendheid in het schieten.

Het meest gebruikte jachtwapen is wel de lans, in allerlei vormen. De lans met breede ijzeren punt, de kuama, is dan de meest gebruikte, maar ook gebruikt men wel bamboelansen. Ook heeft men lansen met weerhaken, o jahan a, vooral voor de varkensjacht, daar men deze dieren meer slapend afmaakt, als zij zich in een soort nesten verscholen hebben, dan wel op de vlucht velt.

De jager gaat er op uit met zijn honden, o kaho ho hinia, met honden jagen.

Men heeft honden in heele koppels, acht of tien soms, en juist niet tot pleizier van zijn buren, want, aangezien men die dieren, zoo het heet, om ze niet lui te maken, nooit voedt. worden het vreeselijke roofdieren, waarvoor niets veilig is. Zelfs te veld staande mais wordt soms de prooi van dit hongerig gedierte. En wee dengene die er een durft te dooden, want men rekent het, anders vrijwel waardelooze dier, dan plotseling van evenveel waarde als een mensch, en eischt vreeselijk hooge boete. Gewoonlijk blijft iemand die veel jaagt, dan ook maar in zijn tuinhuis hier of daar, ver van de kampong, want anders loopt het niet goed af, niet zonder ruzie tenminste, met zijn buren.

$\mathrm{Hij}$ gaat nu, alleen met zijn lans gewapend, met zijn honden het bosch in, en hebben die het spoor van het wild gevonden, dan gaat de jager met zijn spies hen achterna, en loopt net zoo lang achter de honden aan, totdat deze het dier, hetzij hert of varken, zoowat doodgejaagd hebben, waarna hij het haastig afmaakt, en aan de honden ontrukt, anders blijft er natuurlijk niet veel van over. Aan de honden wordt nu het ingewand en de lever gegeven, dat is hun deel. 
Dat men voor dit soort jacht.over een paar sterke beenen moet beschikken, om uren lang door een oerwoud, soms over berg en dal, de honden te volgen, is wel heel duidelijk. Gewoonlijk hebben dat soort lui ook geen last van zwaarlijvigheid. Voor veel anders dan dit soort jagen zijn ze ook niet geschikt, aan geregeld kampongleven al heel moeilijk te wennen, en het is volstrekt geen uitzondering, hier of daar in het bosch zoo'n oude jager aan te treffen, die ver van alle beschaving, een soort kluizenaarsleven leidt, met als eenig gezelschap, zijn honden. Gewoonlijk zijn die menschen ook juist niet aangenaam in den omgang.

Het varkensvleesch wordt gerookt, en is dan, als tenminste het dier niet al te oud was, niet onsmakelijk, hoewel de afwezigheid van zout het vleesch spoedig in bederf doet overgaan, vooral als het een beetje vet is.

Gewoonlijk heeft zoo iemand wel de een of ander, die het overtollige vleesch komt halen, en het inruilen met een en ander, wat waarde heeft voor den jager.

Men is niet heel kieskeurig op het vleesch, en legt het b.v. als de wormen er uit kruipen, nog maar eens boven het vuur, om het van die indringers te zuiveren, waarna men het nog heel goed eetbaar acht. Ook rookt men het vleesch wel zóólang, dat het met hout niet zoo heel veel verschilt in hardheid, zoodat het alleen nog voor Tobeloreesche tanden vermaalbaar is. Maar in dien toestand is het ook heel duurzaam.

De boog, o to iemi, wordt niet heel veel meer voor de jacht gebruikt, tenminste niet voor die op groot wild. Het geweer heeft dien verdrongen.

Toch heeft men de boog nog wel, uit palmbast gemaakt, o toiemi ma leha, met het koord ma dedeli of ma rukiti, gemaakt uit de bastvezelen van den rukitiboom. Deze vezelen zijn heel sterk en duurzaam, en laten zich tamelijk gemakkelijk in elkaar draaien.

Met de pijl, o toiemi ma ngohaka, het kind van den boog, weet men zelfs nu nog vogels te raken. Bij de Kausche Tobelo's, jaagt men er bij voorkeur nog mede op jaarvogels, o kohe. Deze dieren komen gaarne de rijpe vruchtjes van den waringinboom eten, en nu maakt men, tijdens de vruchtjes rijp zijn, in dien boom een huisje, van waaruit de jager met pijl en boog deze vogels schiet. 
Men heeft nog een soort pijl met een weerhaak, o t o t a merie, waarmede men wellicht vroeger groot wild zal geschoten hebben.

Ook als speelgoed is de boog nog in gebruik, en de jeugi oefent zich er gestadig mede, ook wel door kleine vischjes enz. te schieten. in de rivieren, jo to i-toiemi, zij schieten al maar met pijltjes.

Op open terreinen, b.v. in tuinen, weet men ook heel goed het wild met de lans te gooien, en het is daarbij merkwaardig te zien, hoe ver men deze lansen weet te slingeren niet alleen, maar ook hoe goed men nog op tamelijk verren afstand het wild weet te raken. Gewoonlijk wordt echter op die manier het wild wel gewond maar niet gedood, en dan volgt toch nog altijd een opwindende jacht met de honden, om het te bemachtigen.

Men kent ook het blaasroer, o huhupi, en het gebruili ervan, maar ik heb het nooit anders zien bezigen, dan als speelgoed door kinderen, hoewel die er dan wel kleine vogeltjes mede weten te raken.

Men beweert wel, dat het vroeger ook bepaaldelijk als jachtwapen in gebruik geweest is maar ik geloof dat niet, aangezien het blaasroer, zonder vergiftigde pijltjes niets is. Het veroorzaakt op eenigen afstand toch maar hoogstens kleine wondjes, die alleen vergiftigd den dood kunnen veroorzaken. En aangezien nu wellicht de heele pijlvergiftwetenschap maar op een praatje berust, kan ik me niet voorstellen, dat men ooit iets ernstigs met het blaasroer heeft kunnen doen. Het is waarschijnlijk altijd geweest wat het nu is: speelgoed.

En natuurlijk bemachtigt men ook het wild met strikken, springlansen enz. Men heeft daarbij den gewonen strik, o modoi, van touw, van den arenpalmvezel gedraaid, hoewel men dit touw anders dan gewoon draait, n.l. zoo, dat de draden tegen elkaar inloopen, waardoor het gevangen wild den strik nooit uit elkaar kan draaien, maar dien juist door elke beweging vaster in elkaar draait.

Men bevestigt den strik aan een krom gebogen stok, ook wel aan een jong boompje, zóó, dat door de strik aan te halen, een wervel losschiet, die het hout in zijn gebogen stand hield, waardoor dus de strik sterk naar boven getrokken wordt, zoodat het wild zich ophangt of worgt. Men noemt deze strik naar het soort van wild, waarvoor hij gesteld is. Voor menschen is dit 
niet gevaarlijk, te meer niet, omdat het toestel duidelijk zichtbaar is.

Dat is niet het geval met de voetangels, o batoko, die men van bamboe maakt, en in het bosch neerzet. En nog minder net de hertenwip, o huputu. Dit is een gevaarlijk wapen, want het is een soort springlans die ongeveer ter hoogte van het hertenlichaam, horizontaal gesteld wordt, zoó, dat een passeerend dier, door tegen een touw aan te loopen, het mechanisme in beweging brengt, waardoor de pijl in zijn lichaam dringt.

Men mag dan ook noch batoko, noch huputu stellen, zonder langs alle wegen die naar het terrein leiden, teekens te binden. die het gevaar aanduiden. Bij dag gaat dat dus wel, maar 's nachts?

$\mathrm{Nu}$ doet men het gewoonlijk ook niet dicht bij bewoonde streken, maar toch komt het voor, dat menschen hierdoor getroffen worden. $\mathrm{Zij}$ blijven dan soms zwaar verwond op de plek liggen, tot de jagers komen kijken. Zelden doet men dergelijke dingen alleen, gewoonlijk met zijn beiden. Nu zou men denken, dat dan verlossing voor den ongelukkige nadert, maar helaas is dat nog lang niet altijd het geval. Meermalen wordt deze eerste, min of meer onbewuste misdaad, gevolgd door een tweede opzettelijke, daar men het noodig vindt om het slachtoffer eenvoudig af te maken, om daardoor de eerste misdaad te verbergen. Gedurende ons verblijf te Tobelo, zijn mij meermalen aidus gepleegde misdaden ter oore gekomen, waarvan de daders hoogst moeielijk aan te wijzen waren.

Over het geheel geldt het zetten van deze huputu dan ook als verboden, maar nochthans?

Behalve de reeds genoemde algemeen animistische, zijn mij geen bijzondere ceremoniën bekend, die met de jacht in verband staan, of het moest zijn, dat de jager voor of naast zijn huis, al de bekkeneelen ophoopt van de door hem gedoode dieren. Dat trekt, zegt men, dus is ieder blijde, dergelijke jachttrofeeën naast zijn huis te hebben.

Ook hangt men wel al de varkenskaken aan de takken van een boom, met hetzelfde doel natuurlijk.

Wordt men zich er van bewust, in het bosch verdwaald te zijn, waarbij men bespeurt in een kring rond te loopen, dan schrijft men dat toe aan den invloed van booze geesten, die men tracht te verbreken door onder een luid roepen aan de geesten zichzelf geheel te ontblooten. Men roept de geesten toe: 
snu zal ik jelui beschaamd maken,, en daarna vindt men den weg terug. Het geval zal wel zijn, dat men dan beter op den weg gaat letten, terwijl men vroeger gedachtenloos voortliep.

Tegen het steken der boschluizen, of wat het voor luizen zijn. die de vreeselijke jeuk verwekken, waarmede sommige menschen! in het bosch geplaagd worden, bindt men een varentakje aan den hoed, of steekt dit tusschen de kleeding, maar ik weet niet meer, welk soort varen dit is. Ook wacht men zich in het bosch voor luid roepen of het slaan tegen boomen, omdat anders $d s$ rivieren die men over moet trekken, door de geesten aan het bandjiren gemaakt worden. Dit zal echter naar het mij voorkomt, wel den praktischen grond hebben, niet door lawaai maken het wild schuw te maken.

\section{HOOFDSTUK 28.}

\section{Vrouwelijke nijverheid.}

Vroeger heeft tot de vrouwelijke nijverheid in de eerste plaats behoord: het vervaardigen van kleeding, zoolang n.l. die kleeding uitsluitend vervaardigd werd uit boomschors.

Dat is nu al lang geleden, maar toen wij, vier-en-twintig jaar geleden op Tobelo kwamen, werd nog heel wat boomschorskleeding gebruikt. Ik heb den H. Doop nog wel bediend aan menschen die voor die gelegenheid op hun Zondags waren, d. w. z. gekleed als eenige kleedingstuk met een nieuwe, mooi beschilderde schaamtegordel van boomschors. Ook droegen toen vrouwen nog wel sarongs ervan, en, vooral voor het werk in de tuinen, baadjes, die men voor dat doel verre boven katoenen baadjes verkoos, omdat ze de warmte beter tegenhielden, kotier waren dus. Ook voor den doodencultus had men boomschorskleeding noodig.

Als kleeding wordt zij nu niet veel meer gebruikt, misschien hier en daar nog door een oudje in het bosch, maar of het als belegsel van van de doodkisten ook vervallen is, weet ik niet.

Men gebruikt de schors van verschillende boomen, die men noemt naar de soort van kleedingstukken, die men uit de schors maakte. Ook is het mogelijk dat men het kleedingstuk noemde naar den boom; ik weet dat niet uit te maken. 
De schaamtegordel, die wel vier of vijf meter lengte kon hebben, en uit één stuk gemaakt werd, stelde andere eischen aan de houtsoort dan de sarong, een kortere, maar ook veel breedere lap natuurlijk. De schaamtegordel was aan het breedste eind hoogstens een 40 centimeter breed, maar aan het andere eind niet meer dan 20 centimeters. De sarong is een lap van een 80 à 90 centimeter breedte, en wellicht 1.5 meter lengte.

De schors werd, alvorens bewerkt te kunnen worden, geweekt gedurende een etmaal. Daarna begon men de eerste bewerking, kloppen, ho takoro. Men had een soort houten hamer, liever knods, met vier vlakke kanten, wellicht een 10 centimeter in het vierkant. De vlakken waren gegroefd in netvorm. Men gebruikte hard hout, het liefst. ijzerhout. Deze klopper heette o bongono.

De te kloppen boomschors werd op een plank gelegd, en nu geklopt, niet al te sterk, langzaam aan, al rekkende, om de bast soepel en op de noodige breedte te krijgen. Na de eerste bewerking werd weder geweekt, tot men al kloppende en weekende, de noodige breedte verkregen had. Het is een waar geduldwerkje, want door overijling scheurt men de bast maar stuk. Of men de bast ook kookte, weet ik niet.

$\mathrm{Om}$ te versieren, maakte men er wel allerlei figuren op, meest zwart en geel. Geel kleurde men met kurkumasap, en zwart met inkt uit de inktvisschen verkregen. Ik meen haast, ook wel eens licht roode kleuren gezien te hebben.

Onsmakelijk ziet men er door deze kleedingstukken, o hiha, schaamtegordel, en o galoko, sarong, niet uit, omdat men die niet aan elkaar behoeft te hechten. Voor een baadje moet men natuurlijk de stukken aan elkaar naaien, en daar de stof heel wat minder soepel is dan katoen, makt zoo'n baadje juist geen chiquen indruk.

Is dit dus een nijverheid uit een voorbijgegane periode, anders is het met het mattenvlechten.

Deze kunst wordt tot heden beoefend, hoewel ook die sterk achteruitgaande is. Dit achteruitgaan komt nu wel voor een deel, omdat men wel gaarne wat nadoet, maar niet inventief is. B.v. elke familie heeft zoowat haar eigen manier om siermatten te maken; men maakt niet gaarne een model van een andere familie na. Maar nu gebeurt het nog al eens dat een moeder sterft voordat zij hare dochters met deze kunst bekend heeft kunnen maken. 
Heeft nu ook de moeder geen pronkmat achtergelaten waarvan men de patronen kan afzien, dan zeggen hare dochters: wij kunnen geen matten maken. Het eigen patroon kent men niet, dat van een ander volgt men niet, en een nieuw soort vindt men niet uit.

Als materiaal gebruikt men allerlei soorten Pandanus-bladeren. Men ontdoet die van de doornige kanten, maakt ze soepel, door $z e$, òf boven het vuur, òf in de zon, sterk te doen dorren, rolt ze keurig op, en droogt ze nu verder, waarna men ze bewaart tot tijd en wijle men ze noodig heeft.

Het meest gebruikt men een breed soort bladeren, o kokoa, die men aan elkaar naait, om zoo een mat, o kokoa, te krijgen. Men makt die van twee lagen op elkaar gehecht, zoowat 1 meter breed en 2 meter lang. Dit soort wordt in de lengte dubbe! gevouwen, en heet o dodopukuru.

Voor het naaien gebruikt men de bastvezels van Hibiscus tiliacei. De gewone siermat, die men ook als slaapmat gebruikt, is slechts een 70 centimeter breed. Om deze te maken, wordt de bovenste laag bladeren gekleurd. Tot dat doel kookt men de bladeren in allerlei kleurstoffen, vooral geel en zwart.

De eigenlijke versiering brengt men aan aan het boveneind van de mat. Men vouwt zoo'n mat op, op de manier van een kamerschut, in acht slagen en brengt nu op de bovenste slag een extra versiering aan, bestaande uit allerlei vlechtwerk, met mooie figuren, snijwerk met onderlaag van spiesglans, enz.

Ook maakte men vroeger veel grootere pronkmatten van reusachtige afmetingen, waarvan het middenstuk ingenomen werd door allerlei aparte vlecht- en snijversieringen. Jaren en jaren werd over zoo'n mat gewerkt, alleen in den vrijen tijd natuurlijk.

Die matten zijn te zien in het Museum (Prins Hendrik, te Rotterdam, en wie smaak heeft in mooi vlechtwerk, zal het zich niet beklagen, wanneer hij de moeite neemt het daar te gaan bezichtigen.

$\mathrm{Er}$ is een artikel over geschreven door den heer Joh. Snellemans, voorkomende in het Tijdschrift "Het huis, oud en nieuw, jaarg. 1907, afl. 9, waarnaar ik hier wel verwijzen mag.

Het is wel jammer dat deze mooie kunst meer en meer achteruit gaat.

Voor het eigenlijke vlechtwerk is het te betreuren, dat men geen juist begrip heeft van symmetrisch werken. Men brengt het vlechtmateriaal niet op gelijke breedte, en werkt daar- 
daardoor nog al scheef, zonder dat nu zelf op te merken. Dit gebrek schijnen de Tobeloreezen met meer inlanders gemeen te hebben.

Ook maken de vrouwen mooie doozen en doosjes uit hetzelfde materiaal als men voor de matten gebruikt. Allerlei modellen maakt men, en van die modellen geldt weer het\%elfde, als wat we zeiden omtrent de vlechtpatronen: elk heeft zijn eigen, en maakt die van anderen niet na. De mooie hoeden hebben we reeds meermalen genoemd. Ook hiervoor gebruikt men hetzelfde soort materiaal.

Verder vlecht men ook zeefjes, manden enz. Het meest doet men dat in den tijd, dat de rijst te velde staat, en men in het tuinhuis blijven moet om die te bewaken.

Wij hebben ook reeds de fijne bloemen genoemd, die men snijdt uit het zilverachtig bladschee-omhulsel van een enkele bamboesoort, o tetewanga. Werkelijk sierlijke bloemen weet men daarvan te snijden.

Ook moeten we nog melding maken van de draagmanden, eveneens door de vrouwen gemaakt, tenminste degene die men dagelijks gebruikt, de kleine, o kiarono. Ook die wordt heel mooi met allerlei vlechtwerk versierd.

Over het geheel staat de Tobeloreesche vrouw in kunstvaardigheid niet bij den man ten achter, en in al wat ze doet, toont ze ook gaarne die kunstvaardigheid.

Dat over het geheel de vrouw bij de Tobeloreezen niet tot het verdrukte geslacht behoort, zal wel meegewerkt hebben, om die kunstvaardigheid in stand te houden.

Ook is een vrouw, die knap is in allerlei vlechtwerk, hier zeer (ioor in aanzien, en komt men in een woning, waar een heele stapel mooie matten getuigenis aflegt van die kunstvaardigheid der huisvrouw, dan kan men haar geen grooter dienst bewijzen, dan haar te verzoeken, haar schatten te toonen. De adat brengt dan wel mede, dat zij zegt dat het niet veel zaaks is, maar het blijde glinsteren van haar oog verraadt het wel anders.

\section{HOOFDSTUK 29.}

\section{Genotmiddelen.}

Onder de genotmiddelen nemen de pinang en de sirih eene eerste plaats in. Van de laatste, o bidoho, gebruikt men niet het blad, maar de vrucht. Van de pinangnoten, o mokuru, 
heeft men allerlei soorten, ook welriekende, die zeer op prijs gesteld worden, maar toch heeft ook in dezen ieder zijn smaak.

De pinangdoos, o parahangana, groot, vierkant, uit één stuk hout gemaakt, met daarop passende deksel, waarin in verschillende vakjes al de ingredienten die men noodig heeft, is bij ieder te vinden. Ook heeft men wel mooie koperen, zelfs zilveren doozen, o halopa.

De pinangnoot wordt geschild en in vieren gekloofd. De benoodigde kalk heeft men in een apart potje, o tjotjaki. Deze kalk is gewone schelpkalk die ieder voor dit doel zelf brandt, en die men in bamboekokers of in kalebashulzen bewaart.

Men kauwt de sirihvruchten, daar kleine stukjes afbijtende, en steeds eerst het eindje in de kalk doopende, zoo ook de pinangstukjes. Voor bejaarden wordt het wel door jongere personen gekauwd, en hun daarna in den mond gestopt, maar ook hebben tandelooze menschen veelal een bekertje met stamper, om de lekkernij voor zichzelf te bewerken. De sirih is het eerste dat overal gepresenteerd wordt en het is niet beleefd, er voor te bedanken.

Maar ook zonder de aanleiding van een bezoek, pruimt men vele malen daags, hoewel natuurlijk de een er meer aan verslaafd is dan de ander. Sirihranken tegen de boomen, en pinangpalmen, treft men in massa rondom elke nederzetting aan. Zoowel vrouwen als mannen pruimen. Aan een vrouw pinang te verzoeken heeft de figuurlijke beteekenis haar een onzedelijk aanzoek te doen. Een vrouw die zich verheft op haar eerbaarheid, zal men hooren zeggen: ik speel niet met mijn pinang. Kwispedoren, zooals op Java, kent men niet. Elk spuwt maar henen, waar het hem belieft.

$\mathrm{Na}$ sirih-pinang gegeten te hebben, nemen velen gaarne een pruimpje tabak. Dat stopt men niet als in Holland achter de kiezen, maar legt het veel meer voor de tanden, vóór in den mond, z.g.n. om de vochtigheid in den mond te bewaren. Het is nu juist geen appetijtelijk gezicht, een schoone met die versnapering op haar lippen te zien balanceeren.

Aangezien men er niet eigenlijk op kauwt, maar een beetje op sabbelt, kan het ook lang mee, en men legt het eke, het pruimpje, dan ook heel kalm achter het oor, liever: boven tusschen het haar en het oor in, om het ter gelegener tijd vandaar weer naar de lippen te expedieeren. Neen, bevallig is dat alles niet naar onzen smaak, maar wee den man, die zijn vrouw 
dat genot zou willen ontzeggen! Ze liep bepaald bij hem vandaan. De man moet dan ook zorgen dat de vrouw tabaksvoorraad heeft.

Behalve om te pruimen op deze manier, dient de tabak ook om te rooken. Voor omhulsel gebruikt men het jonge arènblad, netjes afgeschaafd, op eindjes gesneden, o gao, waarin men eenige weinige draadjes tabak rolt en de sigaret, o dudu, o huju, is klaar.

Ook hieraan is menigeen verslaafd, zoo zelfs dat men bij uitputting, uit een paar trekjes tabak weer nieuwe kracht schept.

Men rookt nooit veel achter elkaar. Zulk een sigaret is al niet groot, maar soms heeft men voor een man of wat maar één sigaret. Elk doet een paar haaltjes, laat den rook door den neus gaan, en voelt zich nu weer opgewekt, honger en vermoeidheid zijn voor een poos weer vergeten, en men gaat weer moedig aan het voortscheppen der prauw.

Rookt men alléén zijn sigaret op, dan wordt dikwijls ook na een paar haaltjes die achter het oor gestoken, ook wel in het gaatje in het lelletje van het oor, om het tot gelegener tijd te bewaren.

Smakelijk riekt het niet, en vooral s'morgens op den nuchteren maag is de scherpe lucht van de tabak en het palmblad vreeselijk maagtergend.

De Tobeloreesche vrouwen rooken heel weinig, die van TobeloKau bijna algemeen. Ze hebben hare sigaretten veel langer dan de mannen, maar rooken heel sterk. Daarentegen pruimen ze minder tabak, dan de Tobelosche.

De tabak is in den Molukschen Archipel al lang verbouwd. Bij de Tobeloreesche woningen ziet men hier en daar wel een paar planten, ook ziet men wel een enkele tabakstuin, maar eigenlijke tabaksbouwers zijn de Tobelo's niet. Ze zeggen, dat dat is, omdat men zóó gemakkelijk uit elkaars tuin leent, dat voor de eigenaars niets zou overblijven.

Wanneer men n.l. door een tuin komt van iemand met wien men verwant of bevriend is, mag men wel een kleinigheid meenemen, een stuk suikerriet b.v. Men geeft dan een teekentje om aan te duiden dat het niet gestolen is, maar eerzaam meegenomen. $\mathrm{Nu}$ zou bij tabak dat eerzaam meenemen wel zulk een omvang nemen, zegt men, dat de eigenaar niets voor zich zelf behield. Men doet nu ook zoo met de weinige planten, die men hier en daar op het erf heeft. 
De kwestie is evenwel, dat men tabaksbouw niet gewoon is, terwijl de teelt ook nogal zorg vereischt, heel wat meer dan de nogal onverschillige Tobelorees gewoon is te geven.

En men kan het product altijd gemakkelijk koopen, daar het district Galela tabak verbouwt, en het Noordelijkste gedeelte van het district Tobelo ook nog wel wat.

En dan de palmwijn, o daluku! Daarom draait nog al veel in het leven van den Tobelorees. Die is ook niet overal aanwezig, aangezien men de arènpalmboomen nooit aanplant, maar deze alleen in het wild voorkomen. Maar vogels en varkens zorgen wel voor de verbreiding der zaden, zoodat er nog al wat van die boomen gevonden worden. Maar toch bij de eene kampong heel wat meer dan bij de andere.

Een zegen is het juist niet als een kampong zich op dit gebied in het vette der aarde mag vermeien, want, hoewel het gebruik tamelijk onschuldig is, werkt het misbruik toch nog al degenereerend.

Wanneer een palmwijntapper ziet dat een boom een mannelijke bloem uitgooit - de meeste zijn vrouwelijke, maar die tapt men niet - dan begint hij eerst, nadat de stengel goed uitgegroeid is, met tweemaal daags, gedurende een langen tijd, met een houtje den stengel zachtjes te bekloppen, om de sappenloop te versterken. Met hetzelfde doel draait en wringt hij hem geregeld. Is hij op die manier zoover gevorderd, dat de bloemen zich openen, dan snijdt hij de bloemkolf zoover mogelijk van den stam, af en bindt nu onder den afgesneden stomp een bamboekokertje, waarin het vocht vloeit. Vloeit het sterk, dan gaat hij het bamboekokertje tweemalen daags verwisselen, en snijdt telkens met een scherp mes een uiterst dun schijfje van de stomp af, om die weer opnieuw wond te maken, daar anders het sap spoedig zou ophouden te vloeien.

Het sap is sterk suikerhoudend, en gist heel gemakkelijk. Het is zeer zoet van smaak. Aldus zoet, gebruikt de Tobelorees het echter niet. Het is dan ongezond, zegt hij. Hij laat dus, bij het uitschenken, iets achter in de koker, dat verzuurt, en spoedig verzuurt daardoor de heele inhoud, zoodat men nu voortaan alleen maar zure palmwijn krijgt.

$\mathrm{Om}$ den smaak te corrigeeren, wat bitter of wat aromatisch te maken, legt men er wel wortels in, o daluku ma houru, palmwijnmedicijn, maar dit zijn alleen maar smaakcorrigentia. 
Om het sap op de een of andere wijze meer bedwelmend te maken, heeft men geene hulpmiddelen, evenmin om het sap over te halen; men drinkt het zooals het getapt wordt.

Herhaaldelijk is getracht de menschen te leeren suiker uit het sap te bereiden, maar men doet dit niet gaarne, ook wel een beetje tegengehoudcn door het bijgeloof, dat het sap in den boom spoedig opdroogt, wanneer men een gedeelte daarvan met het vuur in aanraking brengt.

\section{HOOFDSTUK 30.}

\section{Muziekinstrumenten.}

Behalve trommel en bekken, waarover we reeds meermalen spraken, kent men nog als muziekinstrumenten: o a rababu, een soort viool, met snaren van koperdraad, waarop men strijkt met een strijkstok, bestaande uit een gebogen houtje, of bamboetje, waarover haren gespannen van arenpalmvezels. Dit geeft een soort vioolmuziek, die echter maar weinig dien naam verdient, want het is niet meer dan een klagelijk gejammer.

Men ziet het instrument heel zelden, eigenlijk alleen maar bij het orkest van een Goeroe-djini.

Verder: o bangihele, een soort bamboefluit, met een vliesje over het mondstuk. Dit instrument ziet men meer dan de arababu, vooral jongelui oefenen zich er op. Mooi is het echter ook niet.

Ook de Europeesche, of liever de Ambonsche bamboefluit, noemt men met dien naam, en heeft men die eenmaal, dan blijkt wel dat het de meesten volstrekt niet ontbreekt aan muzikaal gevoel of gehoor, want men weet daar allerlei aardige melodieën al heel vlug op te spelen.

De o hulepe is een soort gitaar met één snaar, die over een smal ebbenhouten plankje gespannen wordt, hetwelk men weder in een halve kokosnootdop plaatst, die de muzikant met de opening tegen zijn borst zet. De muziek, die men hierop maakt, door te tokkelen met een staafje, of ook met den vinger, is al heel mager.

Het is echter het instrument van de troubadours. Men beweert, dat men met deze muziek bij een nachtelijk bezoek aan eene schoone, staande aan den buitenwand van haar kamertje, van Dl. 78 . 
alles tegen haar zeggen kan. Ik vermoed echter, dat het zeggen ook wel een eentonige muziek zal zijn, die de schoone als ze wil wel zal begrijpen, en anders niet. De betooverende toonen van deze muziek zullen haar hart wel niet bewegen, als ze niet wil.

Ook heeft men de o tatabuang. Dit is niet het onder dien naam in Ternate bekend staande stel bekkens, maar een geleding van een nog al zware bamboesoort, waarvan men, in verschen staat, een strookje van de buitenschil omgevormd heeft tot snaren, en door daaronder een opening te maken, en onder de losgemaakte snaren aan weerszijden een kammetje te schuiven, een soort grove gitaar maakt, waarmede men door tokkelen met de vingers, het geluid, dat op de heusche ta t a b u a n gemaakt wordt, zoo ongeveer nabootst. Natuurlijk is dit instrument nooit van langen duur, want de snaren springen, zoodra de bamboe droog wordt.

Het is echter ook heel gemakkelijk te vervaardigen, en wordt dus nogal gebruikt, niet als instrument voor orkestmuziek, maar voor tijdverdrijf door lieden die eenzaam hier of daar in een hutje zitten, om zich des avonds hiermede wat op te vroolijken.

O goguli, noemt men een schelp, waarin aan het topeind een gat geboord is, waarmede men op de prauwen de wind roept. Men gebruikt er allerlei soort schelpen voor, maar het meest de tritonschelp.

Men heeft nog een soort mondharmonika, o bolitorongo. Het inlandsch instrument zelf zag ik echter nooit, wel natuurlijk allerlei mondharmonika's van Europeesch maaksel, die men ook met dien naam benoemt.

Een koperen trompet noemt men o huwiha. Vermoedelijk heeft men die vroeger wel eens van krijgstochten medegebracht, waardoor men het instrument leerde kennen en noemen.

Ook kent men nu wel de rebana, de korte trom, omdat die voor het $\mathrm{Dj}$ ini-orkest gebruikt wordt, maar een Tobeloreesch instrument is dat niet.

\section{HOOFDSTUK 31.}

\section{De Tobelorees als Mohammedaan.}

Het aantal Tobeloreezen, dat tot den Islam is overgegaan, is niet groot. Dit mag verwondering baren, omdat vroeger van 
de zijde van Ternate, v́an het Sultansbestuur, op dien overgang eene premie stond. Die tot den Islam overgingen n.l. werden gelijk met Ternatanen gerekend en betaalden daarom geen belasting. Zoogenaamd moesten zij ééns per jaar een prauw, een korakora, voor den Koning van Ternate maken, maar dat deed men niet. Nominaal moest een gulden af koopsom per jaar daarvoor betaald worden. Daar echter de belasting vier gulden bedroeg, was dat toch nog altijd drie gulden per jaar winst. Het heeft echter niet velen verlokt, en het zonderlingste is wel, dat men altijd min of meer beschaamd is Mohammedaan te zijn. Vraagt men iemand: waarom zijt ge Mohammedaan geworden, dan begint hij altijd zich te verontschuldigen; het was zijn hart niet, maar het waren de omstandigheden, die hem er toe brachten.

Ook laat hij den Islam betrekkelijk gemakkelijk weer los. Het is ons deel niet, zegt de Tobelorees.

$\mathrm{Nu}$ zal tot dit gevoelen wel vooral hebben bijgedragen, dat de propaganda voor dezen Godsdienst van de zijde van Ternate kwam, dat men juist niet lief had, hoewel Ternate veel te politiek was, om ooit met geweld te Islamiseeren.

Volgens een verhaal onder het volk, is eens vrijdom van belasting aangeboden aan wie den Islam wilde omhelzen, maar eenig gevolg heeft deze aanbieding niet gehad.

Dwang is nooit uitgeoefend, voor zoover mij bekend is, alleen maar waren aan den overgang voordeelen verbonden.

Als Mohammedaan is de Tobelorees niet veel bijzonders. Hij blijft volkomen de oude, gaat met zijn doodenfeesten enz. getroost door, al is het ook onder Mohammedaanschen vorm, en stoort zich verder aan niets. Een oud hoofd, dat jarenlang Mohammedaan geweest was, bekende mij, dat hij nooit meer dan één dag per jaar de vasten gehouden had; dat was zoo zijn gewoonte, beweerde hij. Nu, de Islam vergenoegt zich met heel weinig.

Echter, op zedelijk gebied heeft de overgang soms een slechten invloed, daar de Tobelorees daardoor soms polygamist wordt. Soms, maar ook blijft voor heel velen de oude adat geldende.

Dat echter van den Islam moeilijk een verheffende invloed kan uitgaan, is duidelijk voor wie gezien heeft, dat deze Godsdienst niet de minste moeite doet, om de menschen eenig hooger begrip bij te brengen.

Ik herinner mij nog de levendige verontwaardiging van eenige Arabieren, die op een handelsreis te Tobelo afstapten, en met 
hun z.g. n. geloofsgenooten kennis maakten. Zij voelden zich door de aanraking zóó verontreinigd, dat ze spoedig weer in hun prauw stapten, om den Sultan van Ternate kennis te gaa:? geven, hoe het op Tobelo met den Godsdienst stond. De Vorst zond dadelijk zendelingen om den Godsdienst te doen opleven, en wel een week lang werden de lui naar de dagelijksche gebeden gedreven, maar toen vertrokken de zendelingen weer, en men meende nu voorloopig wel genoeg gedaan te hebben aan het bidden, tenminste, ik hoorde er daarna niets meer van.

\section{HOOFDSTUK 32 .}

\section{De Tobelorees als Christen.}

In het jaar 1898 is onder de Tobeloreezen eene beweging ontstaan naar het Christendom, en velen zijn daarmee medegegaan, hoewel lang niet allen.

De gechristianiseerden zijn langzamerhand in dorpen bij elkaar gaan wonen, en de weldadige invloed van het Christendom is alleen te ontkennen door hen, die willens blind zijn in dezen.

De vooruitgang van de streek is dan ook aan dezen overgarg tot het Christendom te danken. Daardoor toch was met het oude gebroken, en ook het Binnenlandsch Bestuur kon met wat nieuws komen, zonder op niet te overwinnen bezwaren te stuiten.

Ook de Heidenen zijn daardoor op den duur niet de oude gebleven. $Z_{i j}$ zijn ook in veel dingen gemoderniseerd, en hebben onwillekeurig den verheffenden invloed van het Christendom min of meer ondergaan.

Als pionier van het Christendom heeft de Tobelorees veel voór, in zijn brutaliteit, zijn zich op den voorgrond stellen, en ook niet het minst in zijn taaie vasthouden aan wat hij eenmaal als goed erkend heeft.

Eenmaal vertelde me iemand: we moesten hier wel Christen worden, want de Koning van Tolo is het ook geweest. Toen die echter naar den Hemel terugkeerde, heeft hij het Boek der wijsheid meegenomen, en daardoor zijn deze landen in domheid verzonken onder de macht van de Mohammedaansche Ternatanen, maar nu heeft de zendeling ons het Boek der wijsheid 
weder teruggebracht (de Bijbel) en daarmede zullen we nu weer omhoog komen.

Wat de zeden betreft, dronkenschap, ook ontucht, werden met goed gevolg door het Christendom bestreden, en door de alom opgerichte scholen wordt de volksontwikkeling als zoodanig zeer in de hand gewerkt. Door het Christendom kunnen de Tobeloreezen nog een schoone toekomst tegemoet gaan.

Dat dit door vele ambtenaren van het B. B. niet ingezien wordt, is wel zeer te betreuren.

\section{HOOFDSTUK 33.}

\section{Liederen en Raadsels.}

I.

\section{Dopa-dopa.}

1. m. Ma gonaga dokanena, ma gogoru naro naro. Het voorkomen (ervan is) aldus, haal (trek) er de liefde uit.

2. v. Nage joni dokanena, si nowadji ma gogoru. Wie (zijt gij) aldus, dat gij spreekt van liefde?

3.m. Giki jori dokanena, dadi to wadje goguru. Aanzienlijk (ben ik) aldus, dus ik spreek van liefde.

4. v. Ngana ni duga ma laha, na deromidokanena. Het lot is u gunstig, dat gij ons aldus vindt.

5. m. Ri duga ja lahaua, tjara jori dokanena. Het lot is mij niet gunstig, op de manier van aanzienlijke

[lieden aldus.

6. v. Segala biso to biso; afa no oro ma ngale. Allerlei zangen zing ik, neem er geen aanstoot aan.

7. m. Toma doniru ma doja, oro mangale kokoga. in het spel, wat zou men dan kwalijk nemen?

8. v. Ngitu na oro mangale, dadi gena si to wadje. Wellicht naamt gij het kwalijk, dus daarom zeg ik het.

3. m. Ngori doka giki ua, kenebo oro ma ngale. Wij gindsch (zouden)geen menschen (zijn), (als we ook maar)

[een weinig kwalijk namen.

10. v. Ngitu no ma tjara giki, dadi gena si towadje. (ik dacht) dat ge zooals de menschen zijt, dus daarom zeg

[ik het. 
11. m. Tjoba to ma tjara giki, rupa dokanena ua. Komaan, indien ik als (alle) menschen was, dan zou het Tot hier een soort inleiding of voorspel.

[niet aldus zij:

12. $\mathrm{m}$. Ma dero to ise-ise, ngane gè sè ni bobai. Indertijd heb ik gehoord, dat gij een vrijer had.

13. v. Ri lamo ri gaka reni, to bobai jangu modju. Mijn grootte en mijn gestalte aldus, vrij ik nog niet.

14. m. Ni lamo ni gaku gena, ni bobai dofu morua. Je grootte en je gestalte aldus, heb je al veel vrijers gehadi.

15. v. Tjoba no ributu demo, ika no terowi ronga Wel, als gij tegenspreekt, vooruit, maak zijn naam bekend.

16. m. Tjoba to tero wi ronga, nagonahiranomahe Wel, als ik zijn naam zeg, (met) wie, zuster (wordt) gij [beschaamd ${ }^{2}$

17. v. Ti lahi no tero bato, si to mahe ma i laha. ik verzoek, zeg het slechts, en (wordt) ik beschaam!, [maar het is goed.

18. m. Ise-ise ni sabari, biso ma tuka singana. men hoort uw bericht, het onderwerp van de zangen zijt gij.

19. v. Ma dero no ise ika, ngoriua dika giki. toen gij (naar dat bericht) luisterdet, was ik het niet, slech $t s$ [(andere) liedell.

20. m. Ma dero to ise ino, gikiua, dika ngana. toen ik (het bericht) hoorde, waren het geen (andere) [lieden, maar gij.

21. v. Gamukaibe no ise, biso ma tuka si ngori. in welke plaats hebt gij gehoord, dat ik het onderwe:p [der zangen was.

22. m. Gamu.kareni to ise, biso matuka se ngana. in deze plaats heb ik gehoord, dat gij het onderwerp der [zangen zijt.

23. v. Boditoningau pongo, gikima nowadjengori per ongeluk zijn je ooren doof, (andere) lieden, maar gij [zegt (dat) ik ('t ben).

24. m. Ri ngau jo pongoua, giki ma to wadje ngana. mijn ooren zijn niet doof, lieden, maar ik zeg gij.

25. v. Ngau ma gogise salah, giki, ma nowadjengori. 't gehoor der ooren is fout, (andere) lieden, maar gij zegt $i k$.

26. m. Ngau ma gogise tero, giki ma to wadjengana. 't gehoor der ooren is juist, lieden, maar ik zeg gij. 
27. v. Lakoma njonjata ua, taädjirimongo-mongo. er zijn geen ooggetuigen, het is alles laster.

28. m. Lako ma njonjata ngori, ma saidi giki dofu. ik ben ooggetuige, veel lieden zijn er getuigen van.

Ik geef deze liederen, zooals ik ze ook ontvangen heb. De taal is een zonderling mengelmoes van haast alle talen der Tern. Tid. N. Halmah-groep, vermengd nog met Maleisch hier en daar. Natuurlijk is dit niet de oorspronkelijke tekst van deze liederen. Die moet men wel niet op Halmahera zoeken. Echter, ik heb daar ook niet naar gezocht; ik geef wat de Tobeloreezen zingen, niet wat zij eigenlijk wel zouden moeten zingen.

Ik heb verondersteld dat woorden, voorkomende in de GalelareeschHollandsche woordenlijst van M. J. v. Baarda, in de Ternataansch-Hollandsche woordenlijst, voorkomende in het werk van De Clereq, over de residentie Ternate, en in mijn Tobeloreesoh-Hollandsch Woordenboek, bekend zijn, zoodat ik daarvan geen verklaring gegeven heb. Ik verklaarde alleen onbekende woorden. Mocht ik er hier of daar een vergeten hebben, dan zal toch vit de vertaling gemakkelijk de beteekenis van zulk een woord blijken.

1. ma gonaga dokanena, ma goguru naro-naro: dit is de aanvang van zoowat al deze zangen, ook al staat het er juist niet boven; ook hoort men het dikwijls uitgalmen door de een of andere zanglustige vriend, wiens zanglust niet gelijk is aan zijn zangen-kennis.

ma gonaga: het gelaat, het voorkomen van iets of iemand.

ma gogoru: liefde, genegenheid, goede gezindheid.

2. nage joni: wie; half Ternat. half Tidor. si, ook wel: se, en, dat, dus.

3. giki jori: aanzienlijke lui, voorname lui.

4. duga: maat, tijdstip van iets; dug a laha, gunstig tijdstip, gunstig lot.

h. biso: spel; bijzonder: zangspel.

7. doniru: spel, voorstelling; fo toniru doniru: een voorstelling geven.

8. ngitu: wellicht; fo ngitu: meenen, denken; vandaar dat de vertaling dikwerf onzeker is, bijv.: wellicht neemt gij het kwalijk, of: ik dacht dat gij het kwalijk naamt; praktisch geeft dat niet veel verschil, maur omdat men dikwerf, voor de maat, het pers. v.n.w. weglaat, heeft men bij het vertalen de keus, maar ook de pijn.

1i. tjoba: probeeren, maar het wordt dikwijls gebruikt als: stel je eens voor, denk je eens, komaan dan!

12. bobai: beminde, vrijster; ik vertaalde doorgaans het laatste, wel wat plat, maar de bedoeling is ook niet verheven, platter zelfs dan in Holland.

13. ri, verkort van ngori: ik; ook bez. v.n.w. mijn, ons. Tern. gaku: gestalte.

16. hira: zuster, Tob., eohter kan het ook zijn: eerder, eerst, en dus is dit ook vertaalbaar met: wie zoudt gij het eerst beschamen?

18. sabari: zal wel zijn Mal. chabar-habar. Tob. abari, dat men reer verternataanschte met dit: șabari.

tuka: onderwerp, datgene waarover men babbelt.

21. kaibe: welke, welk. Tern.

22. kareni: hier, dit, deze, ik meen. Tid.

28. saidi: getuige. Tern, 
II.

Dopa-dopa, indien mannen op een feest komen.

1. m. Paramata ni manjemo, djirangomimisidola. edelgesteente is uw spreken, slecht is wat wij er bijvoegen.

2. v. Mi ma njemokogaua, no sidola mai laha. ons spreken is (beteekent) niets, voegt gij er wat bij, maar

[het is goed.

3. m. Ngitu asu ni manjemo, dadi gena sito wadji. ik dacht werkelijk dat gij spraakt, dus daarom zeide ik het.

4. v. Gou-goumimanjemo, mangalengonenabiso. Werkelijk wij spraken, omdat wij zangspelletjes doen.

5. m. Ngori ali ma towaro, mangale ngone nabiso. ik ook maar ik weet het, omdat wij zangspelletjes doen.

6. v. Ngitu no na waroua, dadi gena si to wadji. (ik) dacht dat je ons niet kende, dus daarom zeide ik het.

7. m. Ronga horusu marua ho waroua tebena. om zoo te zeggen zijn wij op 't feest gekomen, maar wij

[weten niet hoe.

8. v. Dokagena ka ni ronga, ka ningongadje ma laha. aldus is maar je naam, (en) je zeggen het is maar goerl.

9. m. Ri ronga jo laha ua, iti ri ngongadje tero. mijn naam is niet goed, als maar mijn zeggen juist is.

10. v. Sala ni ngongadje tero, laka daheronga i jali. 't is fout dat uw zeggen juist is, opdat het verkrijgen van [een naam duur is.

11. m. Ronga ja sala marua, si jo tero i tebena. de naam is fout reeds, en hoe zou die goed gemaaktworden.

12. v. Ni ronga batojosala, ningongadje tagigudu. Uw naam slechts is fout, uw zeggen gaat ver (is vermaari).

13. m. Ni ronga to tumubiru, ningongadje to kasuba. Uw naam duik ik in 't blauwe, uw spreken (zeggen) maak

[ik rood.

14. v. Ri ronga kiau modju, tumu biru ma boboso. mijn naam is nog jong (teer), in het blauwe duiken is

[er niet aan geoorloofd.

15. m. Ronga jo himo marua, tumu biruma i laha. de naam is al oud, in het blauwe duiken maar het mag [wel (is goed). 
16. v. Idja dia wo towongi, kasuba wo tola ngolo. groen, hij loopt aan land langs 't strand, rood hij steekt de [zee over.

17. m. Kasuba kiau modju, tola ngolo aku ua. rood is nog jong (teer), de zee oversteken kan (mag) niet.

1. djira = ira: slecht. Tern.

3. asu $=$ wasu: werkelijk, waar. Tern.

5. ali. Tern: $=$ oli. Tob.: ook, nog.

7. fo rusu = ho maruhu: een feest bijwonen. Tob. tebena: hoe, hoedanig. Tern.

10. laka: opdat. Tern.

13. to tumu biru: ik duik in 't blauw, of dook ik in 't blauw, maak ik blauw. kasuba: een roode kleurstof. Mal. kasoemba; to kasuba: ik kleur met kasuba: ik mak rood.

14. tumu biru beduidt ook: duiken in de zee waar die diep is. Er zal wel een schuine aardigheid bedoeld zijn, maar ik begrijp die niet, evenmin als wat de verborgen beteekenis is van de volgende regels.

III.

1. v. Bodito nowaro ngaku, no seba ino kareni. Indien gij per ongeluk weet te gelooven, nader (dan) tot hier.

2. m. To waro ngaku marua, laha marua kareni. ik wist te gelooven, hier is het al goed.

3. v. Nowaro ngaku marua, ma roro na sebaua. gij weet te gelooven, in lang komt gij niet nader.

4. m. Ngaku si to waro bato, to ni bailele modju. te gelooven weet $\mathrm{ik}$ wel, $\mathrm{ik}$ ga nog rondom je.

5. v. Ngomi ne kolanobolo, no ri bailele modju. Zijn wij koningen, dat ge rondom ons gaat?

6. m. To warohirakolano, dadi to ni bailele. Ik weet dat de zuster koning(in) is, dus ga ik rond om je.

7. v. Kara renisi to ise, bala ma i ho kolano. pas hier hoor ik, dat onderdanen tot koning worden.

8. m. Ngori to ise marua, bala ma i ho kolano. ik heb het reeds gehoord, dat onderdanen tot koning worden.

9. v. Ngana na ise marua, ngori walo moi hangu. gij hebt het reeds gehoord, ik nog niet eenmaal.

10. m. Ngana walo moi hangu, ngori dofu marua. gij nog niet eenmaal, ik reeds veel (malen).

11. v. Gam kaibe (si) no ise. bala ma i ho kolano. in welke plaats hebt gij gehoord, dat onderdanen tot

[koning worden. 
12. m. Gam kareni to ise, bala ma i ho kolano. in deze plaats heb ik gehoord, dat onderdanen tot koning

[worden.

13. v. Gam kareni nga hasi, nga biso ja bole-bole. deze plaats hun leugens, hun zang spelen ze zachtjes aan.

14. m. Gam kareni nga tero, hasi ma i to pisaja. deze plaats hun waarheid, leugens maar ik geloof die.

15. v. Bodito ni njinga malo, hasi ma i no pisaja. per ongeluk heb je geen verstand, leugens maar je [gelooft die.

16. m. Bodito ri njinga malo, to dorari rameua. Per ongeluk heb ik geen verstand, ik verschijn niet op [het feest.

17. v. Tjara to dorari rame, ma biso to waroua. als ik het feest bijwoon, de zangspelen ken ik niet.

18. m. No kokaro si to wosa, ri dodego ka i bena. gij roept dus kom ik binnen, waar is mijn zitplaats?

19. v. Ti lahi nowosa ino, dodego i susa ua. ik verzoek je binnen te komen, de zitplaats is geen bezwaar.

20. m. Ngitu ridodego susah, dadigena sitowadje. ik dacht dat mijn zitplaats een bezwaar was, dus daarom [zeg ik het.

21. v. Kananga modju to wadje, ni dodegosusaua. Straks nog zeide ik, je zitplaats is geen bezwaar.

1. seba ino: naderen, dichtbij komen.

2. ngaku: gelooven. Ik heb het ook zoo vertaald; maar volgens anderei: beteekent het in deze liederen: adat kennen, zich weten te gedragen: zooals het behoort.

4. bailele: met een prauw als eerbiedsbewijs om een schip heenvaren, of om een andere prauw, waarin een persoon gezeten is, die men eeren wil. Het wordt echter in deze liederen steeds gebruikt voor: iemand omringen of met eerbied, òf met liefde, met zangen enz.

7. kara: pas, pas nu. Tern.

9. walo: maal. Tern.

13. nga = nanga: hun. hasi: leugen, bedrog. Tern.

14. pisaja, verternataanscht van piritjaja = pitjaja, Tob. pertjaja: gelooven.

21. k ananga: zooeven, straks. Tern.

IV.

1.m. Fola ma doja to suba, gadaria ma tabea. ik betoon eerbied aan het inwendige van het huis, ik groet

[de gaanderij. 
2. v. Ma fola i lahaua, ni oromati na tika. het huis is niet goed, laat je eerbied maar achterwege.

3. m. Fola soreni marua, fo tike tebena jali. Dit is het huis reeds, hoe (dus) nog te zoeken?

4. v. To ngitu ma fola djira, dadi gena si towadje. ik dacht dat het huis slecht was, dus daarom zeide ik het.

5. m. Toma dunia nga fola, ho tike tebena $\mathrm{i} j a \mathrm{li}$. het is een huis van de wereld, hoe zoeken we dus nog.

6. v. Moi-moikanga fola, djiramaboloi ngomi. (Van) alle (menschen) hun huizen, is het onze 't meest

[slecht.

7.m. Fola ne ma katu pipi, ma beno-beno rupia. de dakbedekking van dit huis is geld, de wanden zijn guldens.

8. v. Fola ne makatubobo, ma beno-benosalipi. de dakbedekking van dit huis is van lontarbladeren, de wanden aaneengeregen sagoebladeren.

9. m. Fola nemakatunguki, mabeno-benogarade. de dakbedekking van dit huis is uitgesneden, de wanden zijn vlechtwerk.

10. v. Fola ne makatungusu, masurabikano-kano. de dakbedekking van dit huis is van gras, de afdaken van

[grof riet.

11. m. Fola ne ma katu kaja, ma bodiku rahamati.

de dakbedekking van dit huis is rijk, de bindsels ervan zijn gezegend.

12. v. Fola ne makatu hali, ma surabi misikini. de dakbedekking van dit huis is duur, de afdaken zijn arm.

13. m. Fola ne ara ma bane, sakosi mabunga-bunga. dit huis is (als) 't opkomen der maan, gevlochten met

[bloemen.

14. v. Fola ne ma dabi salah, ma libuku tero ua. de verbindingen van dit huis zijn fout, de hoeken zijn [ongelijk.

15. m. Fola ma tube manuru, ma liate saja gabi. de top van het huis is van manoeroe-bloemen, de palen

[zijn van gabi-bloemen.

1. fol a, ook folo: huis. Tid.

3. soreni, deze, dit. Tid.

10. $\mathrm{ngusu}=$ alang-alang: gras; kano-kano: een groote rietsoort. Tern. 
11. bodiku: binden, bindsel, band. Tern.

13. ara ma bane: maansopgang, wellicht dichterlijk voor: goud. Tern.

14. dabi: de plaats waar men de balken bij elkaar brengt, of aan elkaar hech.

15. manuru: dubbele jasmijn; gabi: enkele jasmijn.

\section{V.}

1. m. Gurasi ni biso modju, salaka ngomi mi tagi. Uw spelen is goud nog, wij zijn zilver, wij gaan.

2. v. Ma gurasi to ni badu, salaka ho biso modju. wij houden het goud voor u terug, wij spelen het zilver nog.

3. m. Dodagi lenge marua, no ri badu-badu ifa. (ons) gaan is ver geweest, houd ons (dus) niet terug.

4. v. No lenge ika marua, to ni sibobadu biso. gij hebt ver geloopen, ik houd u terug door het spel.

5. m. Dokane to tagi modju, walo moi si fo biso. aldus ga ik nog, een (andere) maal spelen we.

6. v. Dokane ho biso modju, walo moi si no tagi. aldus spelen we nog, een (andere) maal gaat gij.

7. m. Ti lahi fo sone ifa, walo moisi fo biso. ik verzoek, zoo we niet sterven, een (andere) maal spelen we.

8. v. Hadjali ma gudu modju, ma sisaro no sone. het levenseind is nog ver, (alleen door) bezwering sterft ge.

9. m. Hadjali lofo marua, sisaroua to sone. 't levenseind is reeds dichtbij, zonder bezwering sterf ik.

10. v. Lefo ti na dulu ino, hadjali fo waroua. Het noodlot achterhaalt je wel, 't levenseind weten we niet.

11. m. Lefo ja tego nonaga, hadjali fowarobato. Het noodlot blijft zooals het is, 't levenseinde weten we maar.

12. v. Lefo tego tena gia, ho ma wale sio doro. Het noodlot zit op de handen, wij zwaaien met de handen

[en vallen helaas.

13. m. Lefo tego tenahohu, hadjalihodjoko-djoko. Het noodlot zit op de voeten, (de gedachte aan) het [levenseind vertrappen we

1. De bedoeling is: wij zijn maar zilver, dus bij het goud hier, te gering, dus gaan wij maar weg.

5. dokane: aldus. Tern.

8. sisaro: allerlei vervloekingen en bezweringen, die men aanwendt om iemand van het leven te berooven. Tern.

10. lefo: hier: hetgeen vaststaat, 'tgeen bepaald is, iemands noodlot, dus 
ook uiteinde; het woord beteekent schrijven, dus:'tgeen geschreven staat. teni: voorzetsel: op, aan, in, bij. Tern.

12. ho ma wale: loopen met zwaaiende bewegingen, zooals overmoedig. sio: helaas; doro: vallen, afvallen, figuurlijk voor: sterven.

VI.

1. m. Loloa kanange modju, manjika dika to tagi. de beleefdheidsbetooning straks al, zoometeen slechts ga ik.

2. v. Siloloa ratu moi, ngori to tarima ua.

(al waren het) honderd beleefdheidsbetuigingen, ik neem [ze niet in ontvangst.

3. m. Ngana na tarima ua, dego-dego jo tarima. gij ontvangt het niet, de rustbank ontvangt het.

4. v. Ngori to tarima ua, dego-dego waro koga. ik neem het niet in ontvangst, wat weet de rustbank?

5. m. Ngone ho ma lomo ino, na gogisedego-dego. wij zijn hier bij elkaar gekomen, gij gehoorzaamt (luistert naar) de rustbank.

6. v. Kara renisi to ise, na gogise dego-dego. Hier pas hoor ik, gij gehoorzaamt de rustbank.

7. m. Ngori to ise marua, na gogise dego-dego. ik heb reeds (vroeger) gehoord, gij gehoorzaamt de rust-

[bank.

8. v. Ngana no ise marua, ngori walo moi jangu. gij hebt het reeds gehoord, ik nog niet eenmaal.

9. m. Kanange modju to wadje, na gogise dego-dego. straks nog zeide ik, gij gehoorzaamt de rustbank.

10. v. Gamukaibe no ise, na gogise dego-dego. in welke plaats hebt gij gehoord, gij gehoorzaamt de [rustbank.

11. m. Gamukareni to ise, na gogise dego-dego. in deze plaats heb ik gehoord, gij gehoorzaamt de

[rustbank.

12. v. Bodito ri biso sala, ma roro na sangoua. per ongeluk is mijn spelen fout, in lang antwoordt gij niet.

13. $\mathrm{m}$. Biso ka ma sala ua, ma tjara to sango ua. het spelen is maar niet fout, expresselijk antwoord ik niet.

14. v. To ngitu ri biso sala, dadigena si to wadje. ik dacht dat mijn spel fout was, dus daarom zeide ik het.

15. m. Kanange modju to wadje, biso ka ma sala ua. Straks nog zeide ik, het spel is maar niet fout. 
16. v. Nowadje ma sala ua, koga so no sango ua. gij zegt het spel is niet fout, wat is het dan dat ge nict

[antwoordi.

17. m. Rinjingasaritosango, muraringana no wadje. mijn verstand zoekt te antwoorden, (maar) spoedig

[spreekt gii.

18. v. Tongitu no sangoua, dadi gena si to wadje. ik dacht gij antwoordet niet, dus daarom zeide ik het.

19. m. Bodito ni ngau pongo, sosango no iseua. per ongeluk zijn je ooren doof, antwoorden hoort gij niet.

20. v. Ri njinga jo pongaua, ri ngau bato jo pongo. mijn hart is niet doof, mijn ooren slechts zijn doof.

1. Loloa: allerlei adatsvormen, die men voor het een of ander in acht moet nemen; siloloa: zich met loloa gedragen. manjika: zoometeen, zoo dadelijk. Tern.

3. of: gij neemt het wel niet aan, maar de rustbank heeft het al aangenomer;

5. ho ma lomo: bij elkaar komen, half Tob. half Tern.

11. Ik denk dat in deze regels, waar steeds sprake is van de rust- of slaa bank, wel een verwisseling van $n a$ en $t a, i k$ en $g i j$, plaats gehad heef: Er staat nu altijd $\mathbf{n a}$ : gij, wat maar heel moeilijk een goeden zin geef: Ook zal er aan dat luisteren naar, of gehoorzamen aan de rustbank, wet een verborgen beteekenis vastzitten.

13. ma tjara: met bedoeling, met een wijs van spreken, opzettelijk.

14. sari: verternat. van tjari, zoeken. Mal.; murari: spoedig, snel. Tern.

VII.

1.m. Lugo django ni ma njemo, djira ngomi mi

[sidola. gij spreekt op mooie wijs, wat wij er bij doen is slecht.

2. v. Mi ma njemo koga ua, mi na sigaro na biso. ons spreken beduidt niets, wij wekken u op tot spelen.

3. m. Ngitu wasu nimanjemo, dadigenahito wadje. (ik) dacht werkelijk dat gij spraakt, dus daarom zeide ik

[het nog.

4. v. Gou-goumimanjemo, mangalengonenabiso. Werkelijk wij spreken, omdat wijlieden spelen.

5. m. Modju si no wadje ua, kara reni si no wadje. nog zeidet gij niets, nu pas spreekt gij.

6. v. Modju to wadje marua, ma tjara no ise ua. nog heb ik al gesproken, om zoo te zeggen, gij hoort niet. 
7. m. Bodito ni ngau pongo, wadje ma no ise ua. per ongeluk zijn je ooren doof, spreken maar dat hoort

[gij niet.

8. v. Ri ngau jo pongo ua, ri njinga bato jo ponga. mijn ooren zijn niet doof, mijn hart is maar doof.

1. Lugo: wijze van spreken, ook: zangwijs.

\section{VIII.}

1. v. Bodito nowarongaku, seba inokarareni. indien gij weet te vertrouwen, kom (dan) hier naderbij [nu pas.

2. m. Towaro ngaku marua, laha marua kareni. ik weet te vertrouwen, het is hier goed. ontbreekt het antwoord der vrouven.

3. m. Karana to daga ino, ma sosonjinga modju. omdat ik pas aankom, ben ik nog in gepeinzen.

4. v. No daga roromarua, so na njinga mega jali. gij zijt al lang aangekomen, dus wat hebt gij nog te denken.

5. m. Saja gabi ni ma njemo, ongowoma pakisani. Uw spreken is gabi-bloemen, het minderwaardige zegt [gij (nog) beleefdelijk.

6. v. Gabidaka mo ma wele, toma manurumadjaga. $\mathrm{Zij}$ hangt daar gabi-bloemen, op de takken van de manoeroe-

[bloemen:

7. m. Toma gamu si to ino, nori jamu, sitowadje. ik kom in de stad, vraag me en ik (zal) spreken.

8. v. Tomagamu si no ino, no gasa abari mega. gij komt in de stad, welk bericht brengt gij.

Hier volgt, zeer verward, 't zelfde als in $N^{\circ} I V$, reg. 7-15.

3. karana: karena, Mal. omdat; daga: komen, aankomen. Tern.

4. mega: wat. Tern.

5. ngowo: het nitgeperste van iets, het uitkauwsel van suikerriet, uitgewrongen cocosnoot e.d.; bedoeld is dus: het vuil, dat wat niets meer waard is; ma pakisani: eerbied, met beleefdheid; wij zouden dns zeggen: het vervelende klinkt uit uw mond nog goed.

6. daka: daar. Tern.

7. jamu: vragen, ondervragen.

8. ga s a : brengen, medebrengen. Tern.

Dit gedeelte was met het volgende hoofdstuk aan elkaar gesehreven, maar wat volgt is duidelijk een andere zang. 
IX.

1. m. Djou ni ma moi moi, fangare suba momoku. gij heeren allen, ik, ik betoon beleefdheid aan de pinang[doos.

2. v. Na tailako i laha, no tede ie no moku. bezie hem goed, beur (hem dan) op om te pruimen.

3. m. To tailako marua, (to) tede ie to moku. ik heb hem goed bekeken, ik beur hem op om te pruimen.

4. v. Ma moku tero marua, salah ma tabako malo. met de pinang is ' $t$ in orde, ' $t$ is fout dat er geen tabak is.

5. m. Ho tego alima ito, ho dero tabakoua. wij wonen aan 't uiteinde (van 't dorp), tabak krijgen [we niet.

6. v. Ma kie bato i djaha, ma bidji i rururu. op de berg is heel veel (tot zinkens), de zaadjes liggen [er heel dicht bij elkaar.

7. m. Mi ma togu ne marua, iti no si boi bato. wij blijven maar hier, als maar gij (uw boosheid?) wegwerpt.

8. v. Fala si no wosa ino, dego-dego si notego. kom in het huis, zet u op de rustbank.

9. m. Fo rusu ramai marua, fo tike tebena jali. wij zijn reeds op het feest, wat zoeken we (dus) nog.

10. v. Sosira ngone na fala, na roraka ma kuasa. vroeger (was dit) ons huis, gij zijt bang voor de machthebbers ervan.

11. m. Kokaro to wosa ika, ri dodego ka i bena. (gij) roept, ik ga binnen, waar is mijn zitplaats?

12. v. Ma djou tego gudu, no tede suba si nage. mijnheer zit ver weg, voor wie makt ge een beleefdheids-

[betuiging?

13. m. To waro djouka nena, to tede suba singana. ik weet dat dit slechts een heer is, ik mak een beleefd[heidsbetuiging voor $\mathrm{L}$.

14. v. Madjou wo tego gudu, na diadi dika ngana. mijnheer zit ver af, verwissel (die plaats) slechts gij.

15. m. Manusia woro ngale, biso se ma siloloa. de menschen nemen aanstoot, spelen (moeten we) op [gepaste wijze.

16. v. Sofutu roromarua, ho ngali-ngali na biso. de nacht is ver gevorderd, (dus) ons spel zachtjes aan. 
17. m. Safutu rorojangu, si fo ngali te i bena. de nacht is nog niet ver gevorderd, en waarom dus

[zachtjes aan.

18. v. Ana gudu ngori gudu, ma dingo-dingokore. zij ver, ik ver, de overbrenger is de wind.

19. m. Njinge sari to ni dingo, kore waro demo ua. mijn hart zoekt je wel te zenden, de wind weet niet te

[spreken.

20. v. Ngana se no waroua, nage la j'ise jo waro. gij weet het niet, omtrent wie hooren zij dat zij het weten.

21. m. Kore koga jo na dahe, matjarangonefotogu. welke wind hebben ze, met reden wij blijven hier.

22. v. Kore jo na dahe ua, tjara ngone fo togu. $Z_{i j}$ hebben geen wind, met reden blijven wij hier.

23. m. Kore ma tai side, ogo modjuho ma tuda. (als er) wind is zeilen we saam, houdt die nog op, dan [komen we achter elkaar aan.

24. v. Daire golebo koga, ma sonanga jo tarangi.

Van over zee komen al windstooten, aan de overkant [wordt het licht.

25. m. Kore pamuru pamara, ma goleboguti-guti. de wind begint te gonzen, de stooten komen aan

[houdend neer.

26. v. Gorua se ma golongi, gogolobe se ma rate. de haven is met ringen, golobeplanten en met kettingen.

27. m. Kananga to ngitu kore, koreua sibu-sibu. Straks dacht ik, dat het wind was, geen wind (maar) [landwind.

28. v. Sibu-sibu ma ja mata, malue j'ado Babale. de landwind is ook op, zij komen niet tot Babale.

29. m. Djangan badiri lama, mara djatuh kabawah. Sta niet lang overeind, maar val neer.

30. v. Njong wo dudu di rumah, Njonja mo pigi

[kebon.

Mijnheer rookt (zit) in huis, Mevrouw gaat naar den tuin.

31. m. Njonja dudukadera, Njong badiri lama.

Mevrouw zit op een stoel, Mijnheer staat langen tijd.

32. v. Djanganbaku liat muka, makutanjabole-bole. ge moogt niet elkaars gelaat zien, elkaar wat vragen heel

Dl. 78.

[zachtjes. 
33. m. Ngori ne to pake buku, se mo bodoh mura ua. ik hier gebruik boeken, en dat zij dom is is niet goedkoop.

34. v. Ma ronga sekola bato, ngone fo ma moi-moi. Zoo te zeggen op school gegaan, hebben we allemaal.

35. m. Ni lefo ma ronga koga, tjoba batja la fo ise. wat beteekent uw schrijven, komaan lees, dat wij het hooren.

36. v. Ngana ne djou hadjikoga, lefo soroga nowar. gij heer zijt wel heer hadji, gij weet den hemel te ve!-

[schrijven.

37. m. Ngori djou hadji marua, lefo soroga towaro. ik ben heer hadji, ik weet den hemel te verschrijven.

38. v. Sirih ada di Kajoa, tabako di Kapo-kapo. Sirih is te Kajoa, tabak te Kapo-kapo.

39. m. Lefo tego tene hohu, hadjalihodjoko-djoko. het uiteinde zit op de voeten, 't einde vertrappen we.

40. v. Mo toku dodoku gaba, mo ma higugu adjali. zij stapt op een brug van sagobladsteelen, zij houdt haar [afkomst op.

41. m. Lefo tego tene gia, ho ma wale sio doro. het uiteinde zit op de handen, met de armen zwaaien, [helaas, vallen.

42. v. Njinga sari to ni mote, bada to kiau modju. mijn hart zoekt $u$ te volgen, (maar) mijn lichaam is nog jong.

43. m. Bada kiau marua, to ni mote jangu modju. het lichaam is jong (geweest?) ik volg $u$ nog niet.

44. v. Gogira djiko padei, ma djiko dodiniru. Stel je voor! 't is hier de bocht van wijsheid, de bocht [van spelen.

45. m. Gabi ne jotu kabena, manuru to ma lilila. Waar ligt deze gabibloem, ik ga een praatje maken met

[de manoeroebloem.

46. v. Daire koga ma ledja, labu njita ma nonako. wat blinkt daar over zee, misschien het voorteeken van

[het licht.

47. m. Njita ma nonakokoru, fa tomo langi sosira. voorteeken van 't licht is de morgenster, wij maken eerst

[rollen (om de prauw op af te sleepen).

48. v. To tugaraie to tola, kadoua te i bena. ik hef een gejuich op, ik steek over, waarom zou ik niet 
49. m. Dowongi ma loa dai, supu hoko fo toniru. het strand aan zee is ruim, uitgaan naar zee om te spelen.

50. v. Djamani ma laku ngana, ta lulu tabolebole. de winnaar van het gelaat zijt gij, ik rol zachtjes.

1. suba momoku: een staande uitdrukking om zeer diepen eerbied te betuigen; momoku: kan zijn: pinangdoos, maao ook: 'tgeen men op de schouders draagt.

2. no tede ïe: beur omhoog; 't schijnt hier echter wel te beteekenen: beur u zelf op; sta op.

6. ma kïè: de berg, echter a.g. z. men daarmede vooral de berg Ternate aanduidt, is het geworden tot: hoofdplaats, stad, dorp, ook wel: eiland. i djaha: het zinkt; het moet waarschijnlijk overdrachtelijk genomen worden, zooals ik het vertaalde.

7. siboi: wegwerpen; ik schreef er bij "boosheid"; bedoeld is natuurlijk de schuwheid, die een aangenaam verkeer tegenhoudt.

10. Misschien moet hier staan, de half verbaasde, half toornige uitroep: gogira! en is de bedoeling: wat! ons eigen huis, en ben je nog bang om binnen te gaan! roraka: vreezen, aarzelen. Tern.

14. ho ma diadi: veranderen, verwisselen.

16. so futu: deze nacht, vannacht. Tern.

23. sai side: het met elkaar opzeilen van verschillende prauwen.

24. daire: overzee, van over zee; golebo: gezegd van de wind, die met korte stooten begint te waaien, om pas later voor goed door te zetten.

26. Waarschijnlijk wordt bedoeld, dat het afscheid moeilijk is, en men door allerlei vastgehouden wordt. golobe: een soort waterplant, waarin men gemakkelijk, bij het waden, met de voeten verward raakt.

27. Met "sibu sibu" wordt de wind bedoeld, die in den nanacht en 's morgens van sommige vlakten naar zee waait, maar bij het booger rijzen van de zon ophoudt, a.g.z. hij alleen veroorzaakt wordt, door het ongelijke afkoelen van land en zee.

28. Dit gezang is herkomstig van Kusu, een dorp in 't Kausche, van waar men het eiland Babale zien kan. Gewoonlijk kan men's morgens wel met landwind van Kusu naar Bobale zeilen.

29. Wat nu volgt, sluit weer niet al te best bij het voorgaande aan. Het is vol met Maleisch, en duidt wellicht op het een of ander voorval in 't dorp, misschien een huwelijksaanzoek.

30. dudu, wellicht: doedoek, Mal. zitten, waarmede het vertaald is; echter is ook dudu: rooken. Tob. Wellicht moet het gecombineerd worden: zit en rookt.

32. bole-bole: zachtjes. Tob.; kan ook zijn: boleh! boleh! het mag. Mal.

38. Kajoa en Kapo-kapo zijn eilanden bezuiden Ternate.

42. bada $=$ badan: lichaam. Mal.

44. dodiniru, van doniru: spelen; djiko: bocht, inham; daar bijna elk dorp aan een meer of minder diepe bocht ligt, spreekt men van $\mathrm{dj} i \mathrm{ko}$ : bocht; men bedoelt het dorp, dat aan de bocht ligt.

45. lilila: praatje maken, bij iemand aanloopen; het kan echter ook beteekenen: "bekijken".

46. ma ledja: de glans, het blinkende van iets; labu: misschien. Tern. 
47. er staat: fato mo langi sosira; dat zou ook kunnen zijn: $\eta^{z i j}$ verlicht de steenen het eerst".

48. er staat: to tuga rai e to tola; dit kan ook beteekenen: „ik heb het afgepast, afgemeten, dus steek ik over.

50. kan ook zijn: djamani ma lako: het oog van het gelaat.

Vanaf regel 38 sluit het weer niet best aan bij het voorgaande. Misschien is het van daar af weer een aparte zang, maar het is alles zeer verward; alsof men maar achter elkaar raak gezongen heeft.

\section{$\mathrm{X}$.}

1. v. Nage ana dokanena, dadi nowadje goguru. Wie is daar aldus, dat gij spreekt van liefde.

2. m. Dä̈e kelapa muda, ka ma lose ada bai. Van over zee komen jonge kokosnoten, alleen die klokken

[zijn goed.

3. v. Kulewa to niginado, njinga makatudju nage. ik jok niet ik vraag je, met wie volgt je hart?

4. m. Lako ma dagi siasa, njinga maka tudjujangu. Het oog gaat gedwongen, het hart volgt nog niet.

5. v. To sidagi budi koga, la se ngori fo mamote. Welke list moet ik aanwenden, opdat met mij wij elkaar

[volgen.

6. m. Ri njinga sari to biso, ma tjilaka ridjolodjo. mijn hart zoekt te spelen, maar helaas mijn keel.

7. v. Moi, moika djolodjo, ma teroua se ngomi. allen (hebben) maar (hun) keel, niet gelijk aan ons? verder als in voorgaande hoofdstukken.

1. De eerste regel, de aanvang, is weggelaten.

2. Minachtend natuurlijk, als zouden de meisjes te jong zijn.

3. kulewa: moet zijn: to kulaiwa: ik jok niet. Gal.

4. siasa: niet vrij, onder dwang staande iets doen. Tern.

6. djolodjo: strottenhoofd, ademhalingswerktuig. Tern.

XI.

O Gule ma betongo (lēlēhe) de woorden (de tekst) van het spel.

1. Lobi dia lobi dai, fira mi lolobi dia. wolken over land, wolken over zee, de zuster haar wolk over land.

2. Mo totumuake Lina, mo fere ie guratji. zij baadt in het meer Lina, zij komt (er uit) op (als) goud. 
3. Mi dodjokotara folori, mi hoheba paramata. haar treden onder (haar) zijn kostbaar hout, haar naderen [is als edelgesteente.

4. Ngitu dia se mo hoko, ino mo rako migia. Wellicht komt ze naar zee toe, komende zwaait ze met

[haar handen.

5. Giki tjawaroma ngofa, he ngone ma dodjoua. $\mathrm{Z}_{\mathrm{ij}}$ is een kind van wijze lieden, wel wij zijn (haar) niet

6. Mi dodoku folori, mi hoheba paramata. [waardig. haar brug is van kostbaar hout, haar naderen is als edel[gesteente.

7. Ngo fira mo django-django, mi dodogu toma [Patani. De zuster is zeer schoon, haar verblijfplaats is Patani.

8. Mi djongutu toma Kau, mi nora toma Galela. haar ligmat is te Kau, haar kussen is te Galela.

9. Mi moku Gamu konora, mi tabako Tarinate. haar pinang (is te) Gamkonora, haar tabak (is te) Ternate.

10. Ma wange i lobi-lobi, dia se mo roka hoko. de zon is bewolkt, zij komt van 't land naar zee wandelen.

11. Ami saja ubo-ubo, mo sitola ubo dadu. haar bloemen zijn oebo-oebo, zij vermengt ze met lichtroode.

12. Mo silolifo manuru, mo sirangi dagasoeli.

Zij doet er nog manoeroe bij, zij omwind het met dagasoeli.

13. Daku tara si wo tara, wi dodumu haerani. Hij komt van boven naar beneden, zijn badwater is wonderlijk.

14. Wo fere ma djumaät, wo usi ma ilala. Hij gaat op (naar de moskee) op Vrijdag, hij doet het «ilala *

[hooren.

15. Ngadji wo hatamu jangu, wo maginadosengori. Hij leest de koran, hij is nog niet besneden, hij vraagt er mij om.

16. Daire i langi-langi, namobanari i temo. Het wordt licht over zee, de waarheidsvogel roept.

17. Bidji jo rangi liketu, wo jotu bale garade. Het onkruid klimt tegen de zijde (van het huis) op, hij ligt [op een uitgesneden slaapbank. 
18. I nita laha wo tagi, namo i fere wo uti. als het goed licht is gaat hij, als de vogels (kippen) opvliegen [gaat hij rusten.

19. Lila ika, lila ino, to lila ino di gamu. daarheen zien, hierheen zien, ik kijk naar de stad.

20. Se ngori ma dodjoua, djolawako to kodiho. en ik ben niet waardig, het is maar beter dat ik terugkeer.

21. Suba no sosere afa. belach niet mijn eerbiedsbetooning.

22. Fo gutji gamu rimoi, fo ma taru bole-bole. in een plaats aan land gaan, zachtjes achteruit loopen.

23. Nako moi i bodito, marai onanga ja nako. indien een een ongeluk krijgt, moet hij zelf dat weten.

24. ngone ka nagara ua. wij zijn zoo wijs niet.

25. Jotu to bolutu jangu, nage ja roka rigumi. (ik) lig maar slaap niet, wie loopt langs mijn touw.

26. Utji to ginado modju, lego ma kapita nage. ik stap aan wal ik vraag nog, wie is het hoofd van het lego-spel.

27. Ma roromagudu eni, karata djoko ni gamu. sedert lang (was ik) ver van hier, nu pas betreed ik uw dorp.

28. Gamu ne kie kolano, ri mahe ri golofino. deze plaats is de koningsberg, ik ben beschaamd, ik ben [bevreesd.

29. Ruku tara silolola, fela ie subu djou. ik buig het hoofd beleefdelijk, ik beur het op, en begroet

[den heer.

30. Ngofa bidji to ma tengo, to dagi-dagi ni rame. ik ben alleen een kind der wildernis, ik kom op uw feest.

31. Ni dorure ma tabea, ri lagu ma pakisani. groeten aan uw voorgaanderij, mijn manieren zijn beschaafd.

32. Domaha ri siloloa. ik zal mij beleefd gedragen.

33. Moleu to dagi-dagi, to dagi tara dowongi. ik loop als een hoopenvormer, ik loop zuidwaarts langs 
34. Ta nonu ie limau, toma tapaki birahi.

ik ga naar boven de stad binnen, op een vroolijken weg.

35. Gamu ma tjahaja gula, ni soa njie goroho. de plaats schittert van suiker, uw voorgaanderij (is vol)

[klapper olie.

36. Kanange ngori to tagi, ngo guru mo siwowasu. Straks ben ik gegaan, vrouw Goeroe had me besteld.

37. To gutji gamu rimoi hadati ta laha-laha. ik ben in een plaats afgestapt, mijn manieren waren heel goed.

38. Djaga gikinga bobai, tjade se ma sitiari. Pas op de lieden hun verloofden, boerten met voorzichtigheid.

39. Ngapo se makira-kira, djou daire ma susa. slaan met bedachtzaamheid, de heer van overzee heeft moeite.

40. Ma bobango ka o njawa.

De betaling ervan is slechts menschen.

2. totumu: herhaaldelijk onderduiken; ake Lina: rivier Lina, meer bedoeld is wel het meer Lina, waaraan de Tobeloreezen vroeger gewoond hebben.

3. djodjoko: bedoeld zijn wel de treden van een trap bij een paalwoning.

4. rako: deftig met de handen zwaaien, zooals alleen een inlandsche dat kan.

5. dodjo: gelijk aan iets, de makker van iets; dodjoua, ongelijk, onwaardig.

7, 8, 9. Hier worden zoowat alle distrioten uit de Residentie Ternate opgesomd, misschien om aan te duiden, dat de persoon in kwestie die alle beheerscht.

11. ubo-ubo: hibiscus, die men in verschillende roode variëteiten aantreft.

12. dagasoeli: een welriekende bloemsoort.

13. dodumu: badwater.

14. usi: Mal. oetjap: uitspreken.

15. dit kan ook wel zijn: ngadji wo ha tammat jangu: hij heeft het koranlezen nog niet voleindigd.

17. bidji: allerlei kruid en onkruid wordt hiermede aangeduid; rangi: opklimmen tegen, zich vasthouden aan; liketu: de kant, zijde, van iets. Tern.

18. als de kippen opstijgen naar hun slaapplaats, dus: 's avonds.

19. lila: zien, uitzien. Tern.

20. djolowako: het is maar beter dat. Tern.

21. sosere: lachen, belachen. Tern.

22. so ma taru: achteruit loopen, hier wel meer: voorzichtig loopen. Tern.

25. bolutu: in slaap zijn. Tern. roka: loopen, langs iets loopen; ri gumi: mijn touw; gedacht is aan een touw, waar de prauw aan vastligt.

26. leg o; hier wordt wel niet uitsluitend het lego-spel aangeduid, maar met dezen deftigen naam het feest bedoeld.

29. fela-ie: het hoofd opheffen, na het eerst groetend te hebben: rukutara, gebogen. 
36. ngo guru: hier kan een vrouw bedoeld zijn die "goeroe" heette, maar anders is het een beleefde uitdrukking om bedoelde vrouw te eeren.

38. tja de: gekscheren, boerten, ook wel: stoeien; sitiari = Mal. istiar: vooruitzien.

39, 40. Of hier een verborgen bedoeling is, weet ik niet; de "heer van over zee" zou de Vorst van Ternate kunnen zijn, maar het woordje ma duidt de heer als een vrouw aan.

XII.

1. Koresara to ni suba, la no gasa ri wowasu. Zuidenwind ik betoon $U$ eerbied, opdat gij mijn bestelling [brengt.

2. La ma gina bangeseli, laka djou mi ma mina. de inhoud van de fluit (het spel), opdat heer (vr.) wij

[elkaar zien.

3. Dodagi to jogo-jogo, i gou to djadjiua. (mijn) heengaan is heel kort, werkelijk ik beloof geen terugkeer.

4. Djadi ma dodola hutu, ngori to domahaua. de verbreking der belofte is (van) nacht, ik wacht er niet op.

5. Ngori ne ta rubangitu, ta ruba ta gou-gou. ik gooi wellicht (de belofte) om, (als) ik omgooi doe ik het [voor goed.

6. Dodagi to jogo-jogo, i gou to djadjiua. (mijn) heengaan is heel kort, werkelijk ik beloof geen

[tijd van terugkeer.

7. To djadji ma ora ua, na tjotjoho pariama. ik beloof geen uur ervan, houdt het jaren (lang) vast.

8. No kauluma habari, no kawing ni rehe bato. gij hoort het bericht, (indien) gij trouwt (is het) uw lichaam [slechts.

9. Bidji bunga bale bunga, daka ja mote fakati. onkruid bloemen, slaapbank bloemen, daar zijn ze 't eens

[geworden.

10. To ise ma tatabua, mi guba rai marua. ik hoor de trommelmuziek, haar gordijn is er al.

11. Ka laha mo siwowasu, la mi doro mi ma mote. ' $t$ is maar goed dat ze kennis geeft, opdat wij tezamen afvallen. 
2. Onder "djou": heer, kan natuurlijk even goed een vrouw verstaan worden.

5. ta ruba ngitu kan ook zijn: ik verander van gedachten.

7. „ma oraua". Dit ora kan zijn horas = uur. Mal. echter ook wel maand. 'Tern.

8. kaulu: hooren. Tern.

10. mi guba rai marua: „haar gordijn is er al" wil zeggen: er is al een apart slaapkamertje voor haar en haar man afgeschoten, m. a. w.: ze is getrouwd.

tatabua: men verstaat hieronder bepaald feestelijke huwelijksmuziek.

\section{XIII.}

1. Doka ma gudu to ino, to n'ise gogoru koga. gindsch van ver kom ik hier, wat hoor ik van je van liefde.

2. La ka dunia ma ronga, iti de mo ngale moi. opdat met name haar te vragen, als 't haar maar eenmaal [naar de wijze der vrouwen gegaan is.

3. Siokona ngori eni, doka sosira reua. helaas ik hier, vroeger was ik gindsch nog niet.

4. Doka saja to doro, ronga to gutji marua. gindsch deed ik de bloemen afvallen, met name ik ben [afgestapt.

5. To sigaro budi koga, kodiho doka sosira. Welke list zal ik aanwenden, (om) 't ginsch (te doen terug[keeren) zooals het vroeger was.

6. Ma roromagudueni, ta djoko ri limau. sedert lang was ik ver van hier, ik betreed mijn stad.

7. Ngo fira to laha ua. Gamu ta roka to mahe. Zuster, ik ben niet goed, langs het dorp te gaan schaam ik mij.

2. misschien: als ze in 's werelds naam maar maagd geworden is.

3. missohien: helaas, als ik ginds vroeger maar niet geweest was. - Dit schijnt wel een klacht van iemand, die zijn beminde achtergelaten heeft, maar elders met een ander overspel heeft bedreven, waardoor hij beschaamd wordt, bij het terugkeeren in 't eigen dorp.

\section{XIV.}

1. Doniru si fo toniru, ma i ka mangaleua. een spel spelen we, maar het beteekent niets.

2. Bada ua loe kamu, la no suka no sukare. geen lichaam, damp slechts, opdat, 'tzij gij vreugd of smart hebt. 
3. Ngori njinga, loa, loa. mijn hart is recht.

4. Ngitu dai toma gura, lohoko mi sora hoko. misschien is de tuin over zee, de landwind brengt haar zeewaarts.

5. Mi oti turi ma bunga, mi sari kelo ma rau. haar prauw is een toeribloem, haar schepper is een keloe blad.

6. Mi liaro dagasuli, mi side gabi ma boro. haar mast is een dagasoeli stengel, haar zeil is een gabi bloem.

7. Dunia to dagi dagi, turu to ngali marua. ik wandel in de wereld rond, later ben ik veranderd.

8. To ma dadi namo koga, to sigaro budi koga. welke vogel maak ik mij, welke list gebruik ik.

9. Kodio doka sosira, aro tomo si godio. terugkeeren gindsch waar ik eerst was, tegen den stroom [in terugkeeren.

10. Ma i tajako re ua. Maar het waait heelemaal niet.

11. Sosira nage ni sudo, touru no ma toduba. Wie zond (bevel) u vroeger, later zult gij er spijt van hebben.

12. Nage sudo no ma bugo, no ma sifati laranga. Wie beval je jezelf te boego, je te begrenzen met verboden.

13. Na mina gonaga sungi, se no ngali ni bitjara. Gij ziet een ander gelaat, en gij verandert uw spreken.

14. Ka fo diri fo ma lena, na sonjinga bolo ua. Slechts wij zelf wij vrijen met elkaar, wenscht (denkt) gij [(eraan) of niet.

15. Ngori ridjadji se ngana, no sinjinga boloua. ik en gij beloven elkaar, denkt gij eraan of niet.

16. Lena no sinjoi dika, ma teroua se ngana. gij vrijt reeds met velen, niet gelijk aan U.

17. Sio ira to ni wasu, na mote boleu dai. helaas zuster, ik ken je, je liept aan zee over de zandbank.

18. No ma sidjako roregu, fala ne se ma bobito. gij naamt een andere houding aan, dit huis heeft zijn regels.

19. Wosa se ma sitiari. binnengaan met voorzichtigheid. 
20. Ma dero fo ma kaulu, kaulu ngana se ngori. indertijd hoorde men, hoorde men gij en ik.

21. Sebabu ni adji guru, bobaja i dadiua. om der wille van uwe ouders, werd het vrijen niet

22. Sosira ena i gou, wa gutu nane reua. Vroeger was dit heusch, hij plukte hier niets.

23. Togu toma hira bira, marua kare ngongano. verblijven bij de broeders en zusters, reeds zoeken vertrouwen.

24. Gamu ma lamo daeni, no ma sisari ni ngitu. het is hier een groote stad, zoek er voor je je meening uit.

25. Sio fira to ni wasu, ri lolena dika ngana. helaas zuster, ik ken je, mijn vrijster zijt gij slechts,

26. Ngori to lai to hahi, sakisi sedjou wonge. ik vloek en bezweer het, getuige is de stamvader.

27. Fira pago mo wowasu, ta tudu ri moku modju. Zuster pago weet (erkent), ik plant mijn pinang nog.

28. Kabila gapi mo reno, tolu se ma bunga bunga. zij snijdt het spiesglans voor een doos, een hoed met ver-

[sierselen.

29. Hukum bolo kimalaha, Sangadji ni horomati. Stamhoofd of dorpshoofd, districtshoofd, uwe eerbied.

30. To fere kolano doro, utji la fo sango suba. ik klim op tot koning ik val, afdalen om de beleefdheid [te beantwoorden.

31. Ruku tara siloloa, fela ie suba Djou. een behoorlijke buiging maken, het hoofd opheffen om de [heeren te groeten.

32. Ngone fo legu daeni, toma limau Kolano. wij spelen hier het legoe-spel, in de koningstad.

33. Kiatjili jo ma fato, Bobato jo ma rimoi. Prinsen staan op een rij, zij allen zijn Hoofden.

34. Manuru jo ma bitjara, Gabi jo ma kira kira. Hun raadslaan is manoeroe, hun overlegging is gabi.

1. ma i ka mangaleua kan ook zijn: je moet er niets achter zoeken.

2. Of deze vertaling goed is, weet ik niet; ka mu: lichte wolk; löe: meer, slechts? 
4. gura: tuin, maar wellicht is hier "tiland" bedoeld, hoewel dat in het Tern. gura ma ngo fa heet. Er is echter spraak van ,over zee gaan", dus is het hier wellicht: „eiland"; lohoko: landwind. Gal. sibu-sibu.

5. "toeribloem". De boom heet ook in het Mal. toeri; het is een nog al groote bloem.

sari: schepper. Gal.; kelorblad, een smal blaadje; de boom heet in 't Mal. ook pohon kelor.

7. turu heb ik hier vertaald met nlater". Het kan ook zijn gelijk toer oet: volgen. Mal.

8. a ro heb ik genomen als haroes: stroom. Mal.

10. tajako $=$ taloko: waaien. Tob.

12. bugo: zie hoofdstuk "Fetissisme".

15. Misschien moet hier wel een verleden tijd staan, die er om de maat uitgevallen is.

16. ma teroua se ngana kan ook wel zijn: het is niet in orde met je, het staat niet goed met je.

17. ir a, verkort van het Tob. iranga: zuster.

21. bobaja = bobai: vrijen.

23. kare: bezien. Tern.

25. "Si o" vertaald met "helaas" is ook dikwijls in lichten graad "och!"

27, 28. De bedoeling is wel, dat er een te vertrouwelijke verhouding bestaat als gevolg waarvan de vrouw sich voor het huwelijk klaar maakt, door voor zich een mooie doos te maken, voor haar aanstaande man een mooie hoed.

33. kiatjili $=$ kaitjil: prins of vorst, de oudste titel van de vorsten der Molukken.

XV.

1. Ri ngitu mo kokiau, muna ngolo ma sananga. $\mathrm{ik}$ meen dat zij jong is, zij is aan de overzijde der zee.

2. Ami jene to hidingo. Haar jonge pinanggenoten zend ik haar.

3. To mi kado bolo ua, wako ino to ginado. Bereik ik haar of niet, rondom vraag ik het.

4. To mi kado bolo ua. Bereik ik haar of niet.

5. To ngo turi i ngitu ngana ire to mangaku. Vrouw toeri haar meening, gij naar boven, ik stem toe.

6. Dadi to ruba ni ngitu. Dus gooi ik uw meening om.

7. To huba to hiohulu, ni huba ma ronga njawa. ik betaal bruidschat, ik verzoek buitenom (want), uw [bruidschat is een mensch. 
8. Ni huba ma ronga njawa, mai to pai to dafo, Uw bruidschat is een mensch, maar ik kan het ook aanvaarden.

9. Lako to goleu lefo, folo ma bobato ua. ik laat de oogen gaan, de heer van het huis is er niet.

10. Mi lako ma tjobi-tjobi, si to waro mi goleu. $\mathrm{Z}_{\mathrm{ij}}$ wrijft haar oogen uit, en ik weet (ken) haar uitzien.

11. Boki Todore mo ino, mo gasa mo legu-legu. Princes Todore komt, zij brengt het legu-spel mee.

12. Ho ise mi tatabua, (mi) paju folo marua. wij hooren haar feesttrom, haar zonnescherm is al dichtbij.

13. Ma wanga i lobi-lobi, i ara gogoro dia. de zon is bewolkt, als de maan opkomt noodigen zij land-

14. Labu ma lefo i ronga. [waarts. Misschien is zijn naam geschreven.

15. Labu ma lefo i ronga, si tau dai garaki. misschien is zijn naam geschreven, en de 10 prauwen zee[waarts bewegen zich.

16. Toma dunia daeni, tjawali ira ha wango. op deze wereld, slechts slecht (is het) te leven.

17. Hio i harumarua, gamamukie kiloli. helaas ' $t$ is al gekomen, duisternis omringt de berg.

18. Ngo fira mi pare ngone, mo rihudu si(mo) fere. de zuster haar pinang zijn wij, zij fluisterde mij toe en klom op.

19. To garaki si to umo, mo ri hia lo migia. ik ontstelde en wierp (het) weg, zij stak mij ook haar hand toe.

20. Wange tumu dieni, ika noma goru-goru. de zon zinkt ten onder, vooruit overpeins maar.

21. Borero na djailili, rowawahu kamu-kamu. bestel het maar aan uw ouders, geef het te kennen aan de [wolken.

22. Dau ma lolinga ile, ma nonu djole ma bati. Van beneden wandelt ze naar boven, ze gaat tusschen het [zeewier.

23. Boleu ma motedai, mo mi hidjaku roregu. Ze volgt aan zee de zandbank, ze gedraagt zich anders. 
24. Badju idjo mo hohira, kasuba mo totouru. Eerst droeg ze een groen baadje, later een rood.

25. Dau ma lolinga ile, badju idjo mo towongi. Van beneden wandelt ze naar boven, (met) een groen baadje

[gaat ze langs het strand.

26. Rafi idjo motowongi, boleu ma motedai. (met) een groene sarong gaat ze langs 't strand, ze volgt [aan zee de zandbank.

27. Boleu ma mote dai, roregu ho makidjaku. Ze volgt de zandbank aan zee, wij gedragen ons anders

[tegenover elkaar.

28. Nitu dai toma gura, lohokomi horaoko.

Misschien in den tuin zeewaarts. (met) den landwind steken

[we over naar zee.

29. Mi oti turi ma bunga, mi sari kelo ma rau.

Haar prauw is een toeribloem, haar roeispaan is een keloeblad.

30. Mi liaro dagasoeli, mi side gabi ma boro.

Haar mast is dagasoeli, haar zeil is een gabi-bloem.

31. Dai ma ngongadje isa, djouma ngofa jo kawi.

Van over zee kwam 't bericht landwaarts, de koningskinderen

[huwen.

32. Ma pake tjara tjina, mi djaku djou ma ngofa.

Zij kleedt zich op zijn Chineesch, zij gedraagt zich als een

[koningskind.

33. Mi ngate-ngate salaka, la rete ire guratji.

Haar oorhangers zijn van zilver, opgelegd met lagen goud.

34. Djodjarosungi joutji, tomakapali ma doja.

Nieuwe maagden stappen af, van uit het schip.

35. Mo toku dodoku tjina; mo ma lenge maradika. Zij stapt over de Chineesche brug, gaat recht door naar

[Maradika.

36. Mi dodego kurisi, mi paju dara ma lofo. Haar zetel is een stoel, haar zonnescherm een paar duiven.

37. Sofutu to dagi-dagi, ka mi siloloa ua. 's nachts loop ik maar, slechts zij is niet beleefd (vriendelijk). 
38. Ta kololi mi djalena, to bailele mi ngara. $\mathrm{ik}$ ga rond haar venster, ik omring haar deur.

39. Tokokito toma dudu, mina daku toma doja. ik wordt wakker buiten, zij boven binnenshuizes.

40. Fola dia, fola dai, fola ma ronga gredja. huizen landwaarts, huizen zeewaarts, (een) huis heet «kerk».

41. Ngara jana tobi ino, ma liketu jo ma seba. hun deur komt in 't zicht, zij naderen de zijde van (het huis).

42. Ngara ma kutji djodjara, ma salăati ngongare. het deurslot is een maagd, de saläat is een jongeling.

43. Tjapaka dai mo wadje, manuru no hoko modju. aan zee spreekt ze tjapakabloemen, breng nog manoeroe naar [zee toe.

44. Loloro mo dofu demo, djela-djela mo wowasu. Haar vele spreken is loloro, haar kunnen is djela-djela.

45. Borero si poma-poma, Sulasi mo malo afa.

Dat zij volstrekt niet schraal zij, dat haar geen soelasi ontbreke.

46. Daka si mo ruruino, saja ma diforo moi. Daar komt ze aandrijven, als een stel bloemen.

47. Ja babane ma diango, la fola ma barakate. Ze zijn goede buit voor de aanlegplaats, opdat het huis [gezegend zij.

48. Futu räa fo mi oro, laka ngone ni leleani.

Over vier nachten halen we haar, opdat wij haar bedienen.

2. jene: jonge pinangnoten, zooals jonge meisjes die gebruiken. Tid.

7. "hiohulu", men verstaat er onder, iets vragen, niet langs den adatweg, b.v.b. een meisje vragen, zonder eerst naar haar ouders te gaan, als men b.v.b. weet dat de geëischte bruidschat te hoog zijn zal.

9. Misschien hoort "lefo" wel bij het $2^{\bullet}$ gedeelte van de strophe, zoódat dat beteekent: zekerlijk! de huisheer is er niet.

12. folo: dichtbij.

14. Kan ook zijn: misschien heeft zij zijn naam vastgesteld, m.a.w. heeft zij haar keus bepaald.

15. tau: mogelijk dat dit wel als "huis" bedoeld is, maar het is in beide gevallen nog al onbegrijpelijk.

19. wierp het voorstel weg, natuurlijk.

21. borero: ouders; djailili: bestellen, kennis geven. Tid.

22. djole: een soort zeegewas, dat op sommige tijden van 't jaar het strand heelemaal bedekt. 
31. „djou ma ngofa" kan zijn: koningskinderen, maar ook wel lui van minderen rang.

33. rete, ire, ik vertaalde: opgelegd, want; rete: laag, verdieping; ire: omhoog.

35. "maradika"; ik heb aangenomen, dat hiermede een kampong bedoeld wordt.

39. m. a. w.: zij laat mij niet binnen.

42. Of hier werkelijk de sala ä, het Mohammedaansche gebed, bedoeld is, weet ik niet; misschien heeft er gestaan: sekilwak, verternataanscht Hollandsch "schildwacht". Dit geeft wel een goeden zin.

43. tja paka-bloem: een soort geurige bloemen.

44. loloro: een soort kruipplant, die alleen lange zee groeit; djela-djela: een soort kruipgras, dat alleen verder landwaarts gvonden wordt.

45. Ik weet niet, wat dit eigenlijk is; het kan ook zijn: " de ouders verbieden het", maar dat geeft volstrekt geen zin; sulasi: een soort geurig kruid, als specerij gebruikt.

47. babane: aanlegplaats voor prauwen; ma diango: zijn buit, winst, voordeel.

48. ni leliani: ik vertaalde alsof er stond: mi ni leliani: wij haar bedienen.

\section{XVI.}

Tot een vrouw die overspel gepleegd heeft.

1. Fira dia se mo utji, mi saja turi ma bunga.

Zuster is aan land gestapt, haar versierselen zijn toeri-bloemen.

2. Mo lenge njira-gubadi, segala saja ma boro.

$\mathrm{Zij}$ gaat links en rechts (naar) alle bloemknoppen.

3. Laka mina moi-moi, labu-kie ma kololi.

Opdat ze ze allen beziet, misschien gaat ze de stad rond.

4. Alam ma Djou mina.

De Heer der wereld ziet het.

1. Met de groote toeribloemen versiert zich natuurlijk geen eerbare vrouw.

XVII.

Wanneer iemands meisje met een ander getrouwd is.

1. Dai ma ngongadje isa, Wasu ri ngitu mo lena.

Van overzee kwam het bericht, werkelijk meende ik, dat

[zij vrijde.

2. Ka laha no siwowasu, la fo doro fo ma mote.

't is maar goed dat gij het weet, opdat we tezamen afvallen.

3. Ise ami tatabua, mi guba rai marua.

Hoor haar feesttrom, haar gordijn is er al.

2. „la fo doro fo ma mote" kan ook zijn: opdat liefde bij beiden tezamen afvalle of ophoude. 


\section{XVIII.}

Om te vragen tot den morgen te spelen.

1. Ma wange jo lobi-lobi, mo ma torifa mi ngara.

De zon is bewolkt, zij staat voor haar deur.

2. Mo penga-penga sulepe, i feto segala ronga.

$\mathrm{Zij}$ tokkelt haar viool, het zegt van alles.

3. Daire, i langi-langi, fira koketo nomomi.

Van over zee begint het te lichten, slapende zuster sta op.

4. Momi to ni ngadje-ngadje, to ni ngongadje dunia. Sta op, (opdat) ik met u spreek, ik breng je een huwelijks[aanzoek.

5. Ngori dakusi to tara, ta torusu ramenena. Ik kom van boven naar beneden, ik bezoek dit feest.

6. Ruku tara to ginado, lego ma kapita nage, Het hoofd buigend vraag ik, wie is het hoofd van het [lego-spel.

7. Ngori daku si to tara, Ka to utu ri tjapaka.

Ik kom van boven naar beneden, ik pluk maar mijn tjempaka-bloemen.

8. Sulasi se goro-goro, to sigoro njinga modju. Soelasi en goro-goro-bloemen, ik heb nog lust om voor te [zingen.

3. kokito no momi: wordt wakker en sta op.

8. Ik weet niet wat goro-goro-bloemen zijn, maar het is een aanloop om te komen op sigoro: voorzingen, in het tweede gedeelte der strophe.

XIX.

Mannen.

Om een vrouw te vragen.

1. Hira, bira no mangaku, to ma tadu hutu moi. Zusters stem je toe, ik heb een nacht op en neer geloopen.

2. To ma tadu hutu moi, notarima boloua. Ik heb een nacht op en neer geloopen, neemt gij het aan [of niet.

3. Djolo wako to kodiho. Het is beter dat ik terugkeer.

Dl. 78. 


\section{Vrouwen.}

4. Iti hira no mangaku, bolowasu se ngo guru. Als gij maar toestemt broeder, misschien met vrouw goeroe.

5. Iti guru mo mangaku, ngori ma to tarima.

Als (vrouw) goeroe maar toestemt, ik, maar ik neem het aan.

1. to ma tadu: men zegt dit van het stampen van een vaartuig; het moet dus zeker beteekenen: in groote onrust op en neer loopen.

$\mathrm{XX}$.

Aan tafel bij het elkaar eten geven.

1. Penga-penga to ni tana, la no dofo boloua. $\mathrm{ik}$ voer je met de vingers, en eet je of niet.

2. Sio ngori ai mäe, djolo wako to kodio. helaas mijn verlegenheid, het is maar beter dat ik terugkeer.

3. Siokona ngori eni, to ngofa daga Mawea.

Helaas ik hier, ik ben een kind dat komt van Mawea.

4. Njolu ino sio oro, ka djole ma dano bane.

Hier aangedreven helaas, als meevarende op het djole-kruid.

1. to ni tana. Zie Hoofdstuk 16: maka-tana.

2. dofo: eten, voeren, een beetje grof; ai: mijn. Gal.; mäe $=$ mahe Gal., bescheidenheid, verlegenheid.

3. Mawea was vroeger de zuidelijkste kampong van Tobelo, dus daarom misschien voor: ver weg, onbesohaafd. Nu heb ik nooit gemerkt, dat d menschen van Mawea zich de minderen voelen der anderen.

4. njolu: aandrijven. Tid. djole, drijvend zeewier; dano-bane: wie als gast meevaart in een prauw.

De opschriften boven de zangen XVI tot XX heb ik er aldus boven aangetroffen.

\section{XXI.}

Dopa. dopa. gila.

1. Ngori dau si to ie. To ise tifa ma ili.

Tulu to unji ma rame.

To dopa-dopa.

2. Daka jo ma fato hoko. Djodjaromalo.
Ik kom van beneden naar boven. ik hoor het geluid van de trom. ik ga aan land om het feest te

[zien. ik speel dopa-dopa.

Daar staan ze op een rij langs zee. er zijn geen jonge meisjes. 
Karifira moi moi.

O djamani moi.

3. Ngori daku si to tara. Ik kom van boven naar beneden. To dode djou mi tifa. ik hoorde hier haar trom.

To turiani ni rame. ik zit op uw feest.

To dopa dopa.

4. Daka jo ma fato hoko. Daar staan ze opeen rijlangs zee. Mo dite-dite tjapaka. Zij draagt pakken tjampaka-

[bloemen.

Mo kokonora manuru. in 't midden heeft ze manoeroe-

[bloemen.

Parise moi.

5. Ngori dau si to ie.

To lila ie mi gamu.

To denge duka ma doja.

To kolofino.

6. Tomo banga si to hoko, Ta mote-mote moleu.

Ri dagilom o kose dara.

Namo suisa.

7. Dai ma ngongadje isa. Van over zee kwam het bericht. Kolano Rumo wo taga. De Sultan van Turkije is aan-

Toma Moloku Todore. In de Molukken op Tidore. si Tarinate.

8. Tike fira mi dudungo. Ik zoek de zuster haar land. Toma Kajoa ma dudu. aan de achterkant van Kajoa. To deroua.

9. Muka dia muka dai. 't Gelaat landwaarts, 't gelaat

Saja la kari.

Tike gofu kumang-ku- te zoeken koemang-koemang[mang.

Alam mi kiloli. ik vond het niet.

[zeewaarts.

om bloemen te zien.

[kruid.

zij gaat rond de wereld. 
10. Tike fira mi dudungu. Te zoeken de zuster haar land. Sing ofu wali tagi nae. moet men slechts wenden en

Halemuli ami djae.

Kota ma ngora.

Tika djangela.

11. Magonaga dokanena.

$\mathrm{Ni}$ oti nena no pane [hoko no joru.

Ma gogoru naro-naro.

No naroïe ni side.

No höitara ni tolu.

Toma totango ma nje[ku.

No horomati.

12. Tagi tagi toma ngoko.

To derofira rimoi.

Mi utu moa la ote moa.

Mi saja gofu.

o Parada ma ledja ledja.

To mi ko ta gila. gila. Jado mi fola ma lele.

To mi bailele ma djura.

To mi taratibi.

Tede mi suba.

Ake djobubu.

Iè $t a$ fere ta fere.

Toma totumu.

Ja dorari ma ragane. Giki fodi pohaua.
13. Ja dorari isa Mede.

[naar boven gaan.

Halemoeli haar spoed. de deur der vesting. zijn overgebleven de vensters.

Het voorkomen is aldus.

Stap in deze je prauw, roei naar [zee.

Haal er de liefde uit.

Haal op je zeil.

Neem je hoed af.

Boven op de tent.

betoon eerbied.

(Ik) ging op den weg. ik vond een zuster.

Haar haar was recht als moa

[stengels.

haar versiersel was gras (kruid). met haar haartooisel blonk zij. ik omhelsde haar dadelijk. tot voor haar huis.

ik omring haar met eerbied.

ik zette haar neer.

ik betoonde haar eerbied.

$Z_{\text {ij }}$ zijn tegenover Mede. (tegenover) de waterbron. opwaarts ik stijg ik stijg. tot het badwater.

zij leggen de goederen neer.

de lieden zijn niet in staat tot

[koopen.

14. Tjaparua si to tara. Van Tjaparoea ga ik Zuidwaarts.

Todore jake Tarinate. op Tidore volgt Ternate.

Kokorona mara touru. in 't midden kom ik maar ach-

[teraan. 
Fodi hena toma teda. pinang koopen aan de uitstalling. Ma pipi malo. geld er voor is er niet.

Bido ka ma sofo ua. Dohai se malo. de sirih heeft geen vruchten. en kalk is er ook niet.

15. Ja dorari Tarinate.

Ze zijn tegenover Ternate.

Se makadato se ma sigi. met zijn paleis en zijn moskee. fat o- fato. op een rei.

Gahi gura mantara.

een tuin maken op het eiland

[Maitara.

Ja dorari oko ngolo. Ze zijn zeewaarts tegenover de

Ngolo kokotu.

[zee.

16. Fola dia fato-fato. Landwaarts staan de huizen op

[reien.

Fola geredja.

huizen (als) kerken.

Ma djalena idjo-idjo. de vensters zijn groen.

Ma bunga ka paramata. de bloemen er van zijn edel-

Ma sofo ka roributu. Ze zitten stijfvol vruchten.

Sebabu djanga ma lefo. want dat niet het uiteinde er zij.

Dika to sone toge marua. slechts indien ik dood ben houdt

[het op.

Nage mina mi barani. Wie durft naar haar kijken.

Hele musingi. een nieuw kleed.

Dunia ma kurati. de aarde is geel.

Alam moi gamamu. de heele wereld is duister.

Ik weet niet, waarom deze zangen dezen naam dragen. Het kan zijn, omdat de maat er heelemaal niet in te vinden is, en dus gila = Mal. gila: gek; ook zou dat nog kunnen zijn om de, van de hak op den tak springenden inhoud; maar het kan ook zijn dat gil a beteekent: rechtuit, rechtdoor gaan, Tob. en dus er op betrekking heeft, dat deze zangen geen beurtzangen zijn.

1. unji, zien, bezien, zonder nog aan iets mee te doen, toekijken.

3. dode: hooren, luisteren naar iets; turiani: zitten, verblijven; parise moi: één paar; ik ben niet zeker van deze vertaling.

5. denge: zitten. Tid.

6. kose dara: zou ook alleen ,jaarvogel" kunnen zijn, daar men in deze zangen dara: duif, ook wel gebruikt voor "vogel".

8. dudungo; in vers 10 komt voor: dudungu, waarschijnlijk hetzelfde woord. Ik heb vertaald: "land", omdat het woord in het Tob. „droogte" beteekent, en dus voor "land", in tegenoverstelling van "zee" gebruikt wordt. Het zou echter ook kunnen zijn dat bedoeld is: dungunu, 
belofte, Tob., waarmede men aanduidt het een of ander voorwerp, dat de schoonzoon halen of zoeken moet voor zijn schoonvader, als behoorende tot den huwelijkschat.

9: Wat koemang-koemang-kruid is, weet ik niet.

10. „na ë"' is vertaald als naik. Mal.

11. regel 1 en 3 zijn kennelijk slechts om de woordspelingen daarmede in 2 en 4. joru: roeien. Tid.; höitara: naar buiten en beneden brengen.

12. moa la ote moa: recht als moa-stengels. moa $=$ marantha dicho. tana Wall., een plant met lange reohte bladstengels. De uitdrukking komt meermalen voor om de schoonheid van vrouwenhaar aan te duiden, misschien om te laten uitkomen dat het niet op zijn Papoesch gekruld is; ma lele: voor Tid. ma djura: passend, eerbiedig; taratibi: schoot; 't kan dus ook zijn: ik zette haar op mijn schoot.

13. Mede en Ake djobubu liggen bij elkar in 't Noorden van het district Tobelo. ma ragane, feitelijk: betaling in goederen, voor een slaaf, een bruidschat etc.

14. Wat met "Tjaparua" bedoeld is, weet ik niet. Misschien $\mathrm{S}$ aparua? maar dat heeft in dit verband geen zin; jake: daarna, vervolgens, Tid. mara: maar. teda: de kleine uitstallinkjes, die men hier en daar in de ramen der huizen ziet, waar men hoofdzakelijk de ingrediënten om pinang te kauwen, of te rooken, te koop aanbiedt.

16. ma bunga ka paramata, kan ook zijn: ze zijn versierd met edelgesteenten. ma sofo $\mathrm{ka}$ roributu, moet missohien 'gelezen worden: maso fo karoributu, warbij maso $=$ masoek, Mal. dus: ze verdringen zich om er maar in te komen. djanga = djangan. Mal. Misschien moet sebabu wel vervangen worden door sebala: och! och! Hele musingi; ik weet hier geen raad mee; misschien moet het zijn: helemu sungi, verbasterd van: selemoet sungi; nieuw kleed. Zoo heb ik het dan ook maar vertaald.

XXII.

1. Bira-bira ho ma djadji. Zusters met elkaar afspreken. Ngana no igo ma kaha. gij houdt van het land. Ngori ta toti ma hate. ik hak het hout ervan om. Rai marua se mahi. Na afloop worden (we) be-

Bira pulo dadiua.

Kana kangela kana ma Om de moeite, om de schade. [rugi.

2. Gahi gura toma buku.

Een tuin maken op den berg, O tola gumi ma djodji. Si.fo kangela. [schaamd.

(want de kleefrijst wordt niet. hij hakt de banen af met moeite. en wij vermoeien ons.

3. Bira ho ma djadji. Zuster met elkaar afspreken. Toma ngowae. bij de mangaboom. 
Ma lofo jo hira jangu. de twee zijn niet vooruit gegaan.

Giki jo ma tahidiri. de lieden lasteren dat.

Ma tufa sakasi.

ma kaha nena.

de eed, getuige.

deze grond.

4. Horu-horu toma ito. Roeien, roeien naar 't uiteinde

[van 't dorp.

To supu dai Batawe. ik ga uit naar Batavia.

To nonu Jaba ma djiko. ik ga de bocht van Ambon in.

5. Ta isa Sula ma dehe. Ik ga landwaarts bij kaap Soela.

To papo Djawa ma dulu. Ik kom dichtbij de Javaansche

[landingsplaats.

Si to ma wako Surabaia. en ik keer om te Soerabaia.

Ake telaga rimoi. (daar is) een meer.

Ma njau gafo segili. de visch daarvan is gapo en aal.

Ma gofu tudju tarate. de planten zijn waterlelies.

Bunga jo ruru.

de bloemen zijn dicht tegen

[elkaar.

6. Dau mo ri dingo ire, Van beneden zond ze mij naar

[boven.

Kabila sigi kolano.

een bladerendoos als een

[koningsmoskee.

Ma doja lele.

de inhoud was sirih.

Kurama no dafo ino. Koerama! vang het op.

Naro se tiba-tiba.

trek (het deksel) plotseling

gij voelt de bedoeling,

Ni bada totagapi.

$[($ open $)$.

Ni njinga.

gij houdt ervan.

7. Dau mo ri dingo ire. Van beneden zond ze mij naar

ma hena kiau ma bido. jonge pinang en sirih.

[boven.

ma kiau dofahe.

die jong is (en) kalk.

ka i katjuba tjatjapi.

slechts is het zegel rood.

ma ja lefo ma ngale maar zij schrijven (het) met

[lamo. [groote redenen,

8. Hena mongetenangara. Lekkere pinang aan de deur. Ma maja teke fiara.

de bloemtrossen hangen tegen

[elkaar omlaag. 
Nengitu giki roregu.

Ka ngone bato.

Giki jang taadjiri.

Ma tjupa daku saksi.

Ma kaha nena.
Misschien andere lieden.

Maar wij slechts.

Lieden die lasteren.

De eed bij (die) Boven (is) ge-

Deze grond. [tuigen.

9. Hena dia toma banga. Pinang, landwaarts in 't bosch. No habari tagi to hira. Gij bericht (dat) ik vooruit ge[gaan ben.

Ma dorari ma Todore. Ze zijn tegenover Tidore. Bido Todore ta fulele. Tidore's sirih vent ik uit.

If a ma rasa $\mathrm{n}$.

Dat maar niet de smaak be[dwelmend zij.

Dai ma ngadje iha. Van over zee kwam 't zeggen [landwaarts.

Tola kaha Dodinga.

Patjikara.

over de landengte van Dodinga.

Tobelo haro Galela. Kaap Patjikara.

Kololi adaka.

Tobelo tot aan Galela.

aldaar rond.

Toma Loloda. Tolofuo. tot Loloda(en) Tolofoeo.

Waioli sitiani.

Waioli Sitiani.

Ibu, se Gamkonora. Iboe, en Gamkonora.

10. Ngori dau si ta ië. Ik kom van beneden naarboven. Djou ni tifa tulu ta unji. Heer (op) uw tifa kom ik aan [land (om) te zien.

Ma rame to dopa-dopa. Het is een dopa. dopa-feest.

Daka jo ma fato hoko. Daar staan ze op een rei langs [zee.

Djodjaro malo tjafu. Er zijn geen jonge meisjes bij. Giki ma bobai to kolo- Ik ben bang voor iemands

[fino.

[vrijster.

11. Dai ma ngongadje isa. Van overzee kwam het bericht [landwaarts.

Sone rimoi ma gonaga. Het was alsof er een dood was. Sungi kota ijka palihara. Nieuw de vesting in (om) ver-

[pleegd (te worden.)

Se ma dihutu gonjawa Als (men) een eigenaar heeft, [malo. [is men geen mensch. 
Kota ika se godiho se Naar de vesting, en terug, heeft [ma dihutu. [men een eigenaar.

12. Dai ma ngongadje iha. Van over zee kwam het bericht

o Sariani wo taga.

[landwaarts.

Toma moloka Todore. In de Molukken (aan) Tidore.

Ternate wo tola ngolo. (Van) Ternate steekt hij de zee

[over.

Wo rosu side talake. Hij hijscht op een zijden zeil.

Wi lewi monga malaju. Hij heeft prachtige sarongs bij

[zich.

Kore wilundjufosai-sai. Met een fluweelen wind wordt

[hij voortgestuwd.

13. Dai ma ngongadje isa. Van overzee kwam het bericht

[landwaarts.

Sone rimoi toma ngolo Een doode midden op zee. ma korona.

Fai kubu toma fasa $\mathrm{mi}$ Een graf graven in de zee maar. fasa esa.

Moku-moku mi soi bau. De golven slaan over hem heen.

14. Dingo toma Mabaino. Van Maba hierheen bestellen.

Dingo gosora. bestellen notemuskaat.

Gosora pakeua, ma bun- notemuskaat is niet goed, de [ga djira. [bloemen zijn leelijk.

Ngori to sidiba kati.

ik weeg af.

ri ma ahi, gosora.

mijn foeli, notemuskaat.

se buah lawa ma tero

[bato.

en kruidnagelen is hetzelfde

[maar.

15. Hate gosora no ma sora. Ga van de eene notemuskaat[boom in de andere.

Laha, laha marah, no (Doe het) heel goed (dat niet)

Tebala sai tjai,tjai. [peka.

No ri riki roro no ri da-

[heua.

16. Daka toma Maribalefira Daar op Maribale sterft gij [no sone.

[zuster. 
Se mi guba wele, wele En haar gordijnen zijn gekruist, [se mi lalanga. [en ze is als een horde.

Toma saha wange safu. Onder de heete zon.

Kara to ngadje tota ha- $\mathrm{Nu}$ pas bericht ik het, breng

[lila. [wilde citroenen.

To ngadji mi kubu ma Ik lees koran op haar graf.

[njeku.

17. Bira-bira ho ma djadji Zusters wij beloven elkaar bij [toma ngoai [de manga.

I hira jangu mare ko- $Z$ ij zijn niet vooruitgegaan naar Lkotu. [den zwarten steen.

Jo ruru gaba ja djaha. Zij drijven(op) sagobladsteelen,

[zij zinken.

Si fo ma hodu bolo kaua. En van elkaar scheiden, of niet

[meer.

18. Wange guratji eni tumu

De gouden zon gaat hier nu [di eni.

Ja mote kie ma dudu.

[onder.

Tumu di eni demo no $\mathrm{Nu}$ onder, je praat onzin.

[1 ib a.

No leko to waroua si- Gij bedriegt, ik weet het slechts [ngofu.

[niet.

Ma bobiawa, kara to Het rechte, nu pas weet ik het. [nako.

19. Tego-tego toma gamu. In de stad (het dorp) verblijven. Ma demo dofu hitana. Daar wordt heel veel naijverigs

[gesproken.

Mai kawasa djololi. Maarhetgaatrond onderhet volk.

To tagi-tagi gura ma Ik ga maar naar het eiland.

[ngofa.

Tike angkal kira-kira. Zoek een weg om te beraden. Kara to dero. Pas nu vind ik die.

1. kana is vertaald als karena. Mal.

2. ma djodji: moeite, bezwaarlijk, vermoeiend.

3. ja ma tahidiri, vertaald als: jo ta ädjiri: zij lasteren. ma tufah moet zeker zijn: sumpah, eed.

6. dafoino: opvangen, ook misschien: ontvangen; bada: voelen, tasten, betasten; totagapi: uitlegging, de bedoeling van iets. 
8. nengitu = misschien; teke fiara: met zijn beiden af hangen, naar beneden hangen; ma tjupa, vertaald als: sumpah: eed.

In $6,7,8$ wordt nogal duidelijk de ontucht uitgeschilderd, zooals die zich op Ternate openbaart.

9. ma vertaald als: zijlieden, eigenlijk: zij, enkelv.; ta fulele vertaalde ik als palele: uitventen; ifa: vetatief Tid.; Sitiani is een kampong in het Waiolische; de voorstelling is, een reis vanaf Ternate, over de landengte van Dodinga, rond Noord-Halmahera.

10. tjafu, vertaald als tjampoer, Mal.

11. Nogal aanschouwelijk wordt hier de werving voor soldaat te Ternate beschreven.

12. lewi monga malaju: een bijzonder prachtig soort sarongs.

fo sai-sai, eigenlijk: zwevend door den wind voortgedreven worden, als bladeren.

13. kubu=koeboer, Mal. graf; fai: maken, graven; fasa: zee. Of de vertaling van de laatste regel goed is, weet ik niet.

14. sidiba kati vertaald als timbang, wegen, balanceeren.

15. In de eerste regel steekt een aardige woordspeling; fo ma sora: oversteken, dus hier van de eene boom in de andere klimmen.

16. Waar Maribale is, weet ik niet; no sone, misschien mo sone: zij sterft; gekruiste gordijnen, en „als een horde zijn", duidt het lijk aan op het doodsbed; wange safu = wange sahu, Gal.: heete zon; kara to ngadji tota halila, misschien: kara to ngadji to tahalila: 't laatste een eigenaardige wijze van koran reciteeren.

17. i hira jangu mare kokotu kan ook zijn: ze gaan nog niet uit het gezicht van de zwarte steen.

18. kie ma dudu, kan ook: achter den berg; ma bobiawa; biawa, Tob. $=$ moa, rechte stengels, dus nam ik aan: $\mathrm{ma}$ bobi a w a $=$ het rechte.

19. hitana = fitnah, Mal.

XXIII.

\section{Rongo-rongo.}

1. m. Ma gonaga dokanena, ma gogoru naro-naro. Het voorkomen ervan is aldus, haal er de liefde, (de

[genegenheid) uit.

2. v. Ngana ni duga ma laha, gikijoni dokanena. Het lot is $\mathrm{U}$ gunstig, aanzienlijke lui (treffen het) aldus.

3. m. Ri duga ja laha ua, sara to ma dokanena. Het lot is mij niet gunstig, mijn wijze van doen is

[maar aldus.

4. v. Dokagenakanironga, kaningongadje ma laha. Alzoo slechts is uw naam. het bericht over $U$ is maar goed.

5. m. Ri ronga ja laha ua, iti ni ngongadje tero. Mijn naam is niet goed, als uw bericht maar waar is.

6. v. Biso bato sé ma ngale, njinga ka mangaleua. Het zangspel heeft maar zijn reden, het hart heeft geen reden. 
7. m. Tomadoniru ma doja, se ma ngale ma i laha. In het spel, zijn redenen zelfs goed.

8. v. Ma dero to tia gane, biso dodure to lupa. In den tijd dat ik op Gane verbleef, heb ik het spel

[zeer vergeten.

9. m. No tia ma roro hangu, se no lupa ma murari. Gij zijt (er) niet lang gebleven, en gij vergeet heel snel.

10. v. Gogira na njinga ngari, rorohang.u ma to lupa. Goed hoor! dat gij mij er aan herinnert, nog niet lang [maar ik ben het vergeten.

11. m. Tifa ma doti labua, na biso ma lugo Gane. De trom klinkt op zijn Laboehasch, gij speelt op de wijze [als de lui van Gane.

12. v. Gogiragiki nga djou, biso ja dumedaua. 't Is mooi hoor, de menschen hun heeren, zijn niet (eens) [ijverig om te spelen.

13. m. Ngori ka rimoiua, bolo wasu dika ngana. Ik nog niet eenmaal, misschien gij slechts.

14. v. Ta dorari rameua, biso ho ma sango-sango. Ik verschijn niet op het feest, spelen (en) we antwoorden

15. m. Rai woi se afa, to waro nga ri popare.

[maar. overleg niet heel veel, ik weet gij zijt mijn geneesmiddel.

16. v. To ma lule ri wadaka, ngori ri modjiu ngana. ik wrijf mijn inwrijfsel fijn, mijn vergift, zijt gij.

17. m. Ruru ho ma mote-mote, ngori ri modjiu giki. wegdrijvende, wij al maar volgen, mijn vergift (zijn) andere

[lui.

18. v. Ruru ho ma mote ua, nganagudu, ngorigudu. wegdrijvende, wij niet maar volgen, gij ver, ik ver.

19. m. Ma douru basa kore, ma sira nage ni sudo. Later onder den wind, vroeger, wie heeft je bevolen.

20. v. Ma douru no ma duba, kore ma dagi tabena.

Later hebt ge er berouw van, hoe is de weg van den wind.

Dit soort zangen zou rongo-rongo heeten, naar het eigenaardig gedempt trommelen, waarbij men de hand op het trommelvel legt, om den toon bij de vlamslagen te dempen.

3. sara $=$ tjara, wijze.

8. tia: zitten, verblijven, Tern.; dodure kan, ook zijn: inleiding tot het spel. Vertaald is als Tob. duru = dure: zeer.

11. Labuha, kampong op Batjan, welks bewoners van Celebes afkomstig zijn. 
15. Misschien waro no, zoo is het vertaald; popare is een vrucht, als groente gebruikt, met bitteren smaak, vandaar wellicht: algemeenen naam voor geneesmiddel.

16. wadaka, inwrijfmiddel, hier bedoeld als tegengift; modjiu, een vergiftige vrucht, daarom vertaald als "vergift".

17. Kan ook: laten we ons maar samen laten drijven.

19. basa kore: onder den wind; ik weet niet of deze vertaling juist is.

\section{XXIV.}

1. m. Lugo django ni ma njemo, djirangomi mi

[sidola.

Op mooie wijs spreekt gijlieden, wij voegen er het leelijke bij.

2. v. Gou-gou ni na njemo, mi manjemo kogaua. Werkelijk gijlieden spreekt, wij spreken niets van belang.

3. m. Ngitu wasu ni manjemo, dadigena sitowadje. Ik dacht werkelijk dat gijlieden spreekt, dus daarom zeide ik het.

4. v. Gou-gou ni manjemo, mangale senganaua. Werkelijk gijlieden spreekt, redenen met $U$ zijn er niet.

5. m. Ngori ali se to waro, mangale se ngana ua. Ik weet het ook wel, redenen (oorzaak) met $U$ is er niet.

6. v. Ngitu mangale se ngori, dadigena se to wadje. Misschien is er redenen bij mij, dus daarom zeg ik het.

7. m. Bodito ho waroua, ka doraribiso ua. Jammer dat wij het niet weten, slechts verschijnen wij [niet bij het spel.

8. v. Bodito ngori to waro, rupa dokanena ua. Jammer dat ik het weet, het is aldus niet.

9. m. Gou-gou goge laha, bodito se no kokaro. Werkelijk wij zitten (hier) goed, jammer dat gij geroepen

10. v. Ri himori gaku reni, to kokarojangu modju. Mijn leeftijd en gestalte is (nog) klein, ik roep nog niet.

11. m. Ni gaku gena i lamo, nokokarogiki dofu. Je gestalte is (al) groot, gij hebt al velen geroepen.

12. v. Gamu kaïbe no ise, to kokarogiki dofu. In welke plaats hebt gij gehoord, (dat) ik al velen

[geroepen heb.

13. m. Gamu kanena to ise, no kokarogiki dofu. In deze plaats heb ik gehoord, dat gij al velen geroepen hebt. 
Veel nieuws staat hier niet in, maar ik geef het, opdat men zie, dat verschillende soort zangen zoowat dezelfde woorden hebben.

4. mangale se nganaua, ook: niet om uwentwil.

10. ri himo, er staat ri hamo, kan dus ook zijn ri lamo: mijn grootte.

\section{XXV.}

Djore.

1. Ma wange ja lobi-lobi. De zon is bewolkt.

Mo ma torifa mi ngara. Zij staat bij haar deur.

Mo fenga-fenga sulepe. $\mathrm{Zij}$ tokkelt de viool.

I feto segala ronga. Die zegt van allerlei.

2. Doka ma gudu to ino. Gindsch van ver kom ik.

Ino si gogoru koga. (ik) kom en welke genegenheid

[(vind ik?)

Iti de mo ngale moi. Indien het haar slechts eens naar [de wijze dervrouwen gegaan was.

Laka dunia ma ronga. Opdat er zoo iets als huwelijksbespreking kon zijn.

Na kodiho se na gamu. Keer terug naar uw dorp.

No gasa ri ngadje- En breng mijn woorden (over). [ngadje.

3. Hate dia toma banga. Een boom landwaarts in 't bosch. Ma bunga ja lahinoko. De bloemen ervan drijven naar

Ma bou doka tjapaka. De geur is als tjampaka.

I dadi ka dagahuli. Het wordt zelfs als dagasoeli.

4. Fira dia ma totomu. De zuster baadt landwaarts.

Ma lutu ake ma utu. Zij zinkt onder in een rivier.

Guihi mo ma jahinoka. De bandjir heeft haar wegge-

[stroomd.

Mi utu bou ja ludja. De geur van haar haar is als

[loedja.

Mi kutu dai dowongi. Haar luizen zijn zeewaarts aan

[het strand.

5. Duko tubo Tarinate. De vulkaan Ternate barst uit.

Djou sora Sidangoli. De Heer steekt over naar Sidan- 
Mi totango ja bilalo. Haar tent is geglansd.

Wi tolu ja bunga-bunga. Zijn hoed is versierd metbloemen.

1. fenga-fenga $=$ penga-penga: met de vingers tokkelen.

4. ake ma utu: zijtak, spruit van een rivier.

5. duko =dukono: vulkaan. Tob.; totango: het tentje op een prauw.

\section{XXVI.}

Djoma.

1. Djulu-djulu gamu Kau ik stap niet in een Kausche [to falenua. [djaloe-djaloe. Selange djou jote to Terwijl de Heer slaapt, stap ik [falenua. [niet in. Singofu guru mo sudo Alleen als vrouw goeroe het ge[kara to fane. [last stap ik pas in. Faneoko, naro side, lebi Instappen zeewaarts, 't zeil op[to djaga. [halen, ik pas op het schoottouw. Lebi wora, bole-bole Schoottouw vieren, zachtjesaan [lulu i poka. [dedeiningslaat (tegendeprauw.)

2. Hira-bira toma kitalima Broeders en Zusters die op het [doja. [erf zijt. Ino to tulu la mi hutu. lk kom hier aan land om te [overnachten.

Tjaka turu ni golongi. met regelmaat tikken uw arm[banden.

Ma i dadi kari boroka. maar het is noodig naar de boro-

Boroka ma ngoi.

Sasi magora.

[kas te zien.

heel veel boroka's.

betaling voor eeden.

3. Lakota goleuika, go- Ik zie uit, daar is een arend. [heba daka.

Ma dodera hate tawa. Zijn zitplaats is een tawa-boom. Ali! ngona se no rogi. Ha, als gij danst klapt gij in de [ni tjako-tjako. [handen.

Luri rimoi ma django. Een mooie loeri, met groene [ma tohe idjo. [staart.

Ma djongihi ngawa- Zijn plaats is in de lucht. [ngawa. 
Matoko bale dika no Zie, klim maar op de ligbank. [pane.

Ika se sinotoka.

Vooruit met zijn beiden.

4. Gahi gura ma galela. Een tuin maken op Galela.

Milo ma dofu.

Heel veel mais.

Kakatua kia isa djaga jo

Pas op de papegaaien van overal

[reno. [van landwaarts die zestukbijten.

Madihutu djaga poi.

De eigenaar past op en gooit ze.

Soro kololi, soro kololi Rondom vliegen, rondom den

[gura.

[tuin.

Gura kakara, hira mo ri Eiland Kakara, de zuster heeft

[kara demo. [me aanhalig toegesproken.

1. djulu-djulu: een soort groote prauwen, die men in 't Kausche maakt. falenua = farenua: niet instappen. Tob.

2. kitali = kintal, erf. Mal.; tjaka turu: regelmatig kloppen, als bij den dans; ik weet niet of het juist vertaald is; boroka = borokata, zie Hoofdst. 24, huwelijk; sasi ma gora = koboto mahohoko. Tob. Hoofdst. 24, huwelijk.

3. goheba, kleine vischarend; matoko: zien. Tob.; er staat ma to toko maar ik weet daar niets van te maken.

4. poi: gooien, werpen. Tern.; Gura kakara kan ook: de tuin waar men iemand aanhaalt, echter is ook mogelijk dat het meer een woordspeling is op kara: vleien, dat volgt.

XXVII.

Wela-wela.

1. Daka ma gudu to ino. Gindsch van verre kom ik hier. Ta torusu rame nena. Ik bezoek dit feest.

Rame ne laha marua. Dit feest is heel goed.

Sala ma dorusu djira. Jammer dat de bezoekers slecht

Difutu bolo madiri. Morgen of overmorgen.

[zijn.

Wako to kodiho-ika. (Is het) beter dat ik terugga.

Suba no sosere afa. Lach niet om de buiging.

2. Tagi-tagi toma ngoko. Op den weg loopen.

Ta dero fira gogoru. Ik vind een lieve zuster.

Mi hutu loa timoa Haar haar is recht als de moa-

Mi saja gofu parada. Haar bloemen heeft ze in de 
Parada mo ledja-ledja. (met de) Haartooi blinkt $z i j$.

3. Lila ika, lila ino.

Hierheen zien, daarheen zien.

To lila ngoko ma doja. Ik zie midden op den weg.

Manuru no tjako tifa. ('t is als) Manoeroe (als) gij de

[trom slaat.

Gabi ne to sigogise. Ik luister naardezegabi-bloemen.

Ino ta unji ma rame. Ik kom om het feest te zien.

Rame daka paramata. Het feest daar is een edel-

[gesteente.

Se ngori ma dodjoua. En ik ben het niet waardig.

4. Kore mie, kore hara. Noordenwind, Zuidenwind.

Ta horu ma kore mie. Ik roei met Noordenwind.

Ta side ma kore-sara. Ik zeil met Zuidenwind.

Rai ma bawo ta mote. Vervolgens volg ik den stroom.

5. Tjai malige bunga-bunga. wegzweven zooals een bloemen-

[paleis.

To gutji gamu tjahaja. Ik ga aan den wal aan de

[blinkende stad.

6. Namo dara, widadari. Duiven, nimfen.

Ngo Guru mi legu-legu. Vrouw Goeroe haar legoe-dans.

Mi douru ngofangare. Haar volgelingen zijn aanzien-

[lijken.

Ami lau mo silila.

Zij laat haar kunsten zien.

Mi tuala gogugia.

Haar hoofddoek is een rood

Mi sosalai bobudo.

[doekje.

Haar djindansen is mooi.

7. Ubo-ubo ri sikai.

Ik huw met de oebo-oebo-bloem.

Sikai ma paramata.

een juweel van een huwelijk.

Labu kië ma kolano.

misschien de berg(stad) des

[konings.

Alam ma djou ngana. de heer der wereld zijt gij.

8. Pariama ri kolano.

Het zevengesternte (is) mijn

[koning.

Ngana ri djou ma ngofa. Gij zijt mijn prins.

To sai ngolo salaka. Ik zeil op de zilveren zee.

Dl. 78. 
To gutji limau djini. Ik stap aan land aan de stad [der djins.

To rame se ni kadato. Ik vier feest in uw paleis.

Se ngori ma dodjoua. En ik ben het niet waardig.

9. Ngori ne iko ma namo. Ik doe zooals de vogels. To soro segala gamu. Ik vlieg naar alle plaatsen. Segala gamu ta njohi. Alle plaatsen tel ik.

To tera djiko rimoi.

Ngofa itji fara-fara.

Siotama, siokona.

To ma singongano [nage?
Ik ga zitten in een bocht (inham).

(daar zijn) allemaal kleine

[kinderen.

Helaas, helaas.

Aan wie zou ik me toevertrouwen?

10. To tego ma gudu eni. Ik verblijf ver van hier.

To ise manuru boro. Ikhoor(van) manoeroe knoppen.

To ino ta tailako. Ik kom (om) ze te bezien.

Gabi djodjaro mididi. Twee maagden als jasmijn.

Ise muna ma garaki. (Ik) hoor haar, zij is ontroerd.

Ri lako ma paramata. Mijn oogen (glanzen als). edel-

[gesteenten.

11. Diare manuru boro. Van over land manoeroe-

[knoppen.

Daire saja kolano. Van over zee koningsbloemen.

Mo ma kuto rorasai. Ze maakt zich heel mooi.

Mo ma saja lola ise. Zij versiert zich met lolaise.

I manuru to si uke. Haar manoeroe breng ik dicht

[bij elkaar.

I gabi to sisasade. Haargabi doe ik elkaar begekken.

12. Nuru dia Radja boki. De manoeroe landwaarts is een

Saja gulugulu eni.

Deze bloem van verre.

Gabi jo tia manuru.

De gabi verblijft bij de manoeroe.

Saja sungi barakati. De nieuwe bloem is gezegend.

Manuru djawa moloku. (het is) Manoeroe. djawa mo-

[lokoe.

Fira to tero ni ronga. Zuster ik herken je naam. 
13. Ngo Bidji-loja mi gamu. Vrouw Bidji-loja haar stad.

Dara bai mi limau. Dara bai haar stad.

Utji mo tomo guratji. Aan wal gegaan komt het goud [haar tegenstroomen.

Saja malige ma rete. Het bloemenpaleis is met ver-

[diepingen.

Sio. ngali mi djamani. Helaas, haar gelaat verandert.

14. Puasa ma ora daka. Daar is de maand van de vasten. $\mathrm{K}$ asuba ma mië nena. Het Noorden is nu rood. Malige idjo i bunga. De bloemen van het groene [paleis.

I dorodalima sofa(sowa). De granaatappels vallen af. Manuru moloku djawa. Manoeroe malokoe djawa. Fira to tero ni ronga. Zuster ik ken je naam.

15. Dia mo towongi tara. Aan land gaat zij Zuidwaarts [langs 't strand.

Fo mi waro ka mi waro. Wij kennen haar, (wij) slechts [kennen haar.

Ma toku gabi ma doja. Zij stapt midden in de gabi [bloemen.

Mo utji manuruboro. Zij stapt aan wal in de ma[noeroe bloemen.

Mo silila ami saja.

$Z$ ij toont haar bloemen.

La i djangu boloua. Of zij mooi zijn of niet.

16. Fira mo budo mo liko. De zuster touwtjespringt mooi. Mi rorangi kotukotu. Zij is met zwart behangen.

Kotu ja dola gonaga. Het zwart klimt naar haar gelaat. Sio! ngali mi djamani. Helaas, haar gelaat verandert.

17. Daku sa mo taga nuru. De manoeroebloem komt van [boven aan.

Mo luluino mo pane. Zij rolt hierheen om in te

Mo tobo ma ngolo hoko. Zij waadt de zee in [stappen. Mi lutu wange rimoi. Zij zinkt een dag lang. Ta sio dika mi djanga. Ikbejammerslechtshaarschoon-

Ta dodora mi djamani. Ik beklaag haar gelaat. 
18. Malige dia mo utji. Landwaarts aan 't paleis stapt [ze af.

Gabi mo tagi dunia. Zooals jasmijn loopt ze opaarde. Mo unji ake sangadi. Zij beziet het Sangadji water. Aralule si palangi. De volle maan is met vlekken. Doka dara toma n'gola. Zooals vogels op de zee.

19. Radja dua ma galela. Twee vorsten van Galela. Mi saja manura nai.

Haar manoeroe-bloem komt

[boven.

Ara lule se palangi. De volle maan is met vlekken.

Doka dara toma ngolo. Zooals vogels op de zee.

20. Lako ta goleu ika.

Fira dodjo sabimoi.

Tagi jo ma tuo-tuo.

Ma njira bolo ma dodjo.

Ma djamani jo ma tero.

21. Tjapaka lue i boro.

Gabi teni soa njie.

Masihoeroe si ta mote.

Ngori ka tobenaua.

Djolo bidji to kodiho.

22. Ora jo ini ta mote. i sora (to) tanobane.

To tanobane ginoti.

To tarabangi si djou.

Ino ta unji ma rame.

Rame daka paramata.

Se ngori ma dodjoua.

23. Lululele-lululele.

Fira to ni lululele.

To ma silahi se ngana.

Ika to gugu ni rame.

Aku bolo aku ua.
Ik geef mijn oogen den kost.

Een span jonge zusters.

Zij loopen met elkaar.

De jongste of de oudste.

Hun beider gelaat is gelijk.

De tjampaka-loëe bloeit.

Jasmijnen in de voorgaanderij. Als de maan ondergaat, volg $\mathrm{ik}$. Ik ga nergens heen.

Het is maarbeter dat ik terugkeer.

Als de maan opkomt ga ik mee. Als hij ondergaat vaar ik mee.

Ik vaar mede op een (stuk) drijf[hout.

Ik kom aan bij de(n) heer.

Ik kom om naar het feest te kijken. Het is een juweel van een feest [daar.

En ik pas er niet bij.

Ik spreek de broeders en zusters

[aan.

Zuster ik spreek $U$ aan.

Ik verzoek aan $\mathrm{U}$.

Of ik voortaan Uw feest mag bij-

Mag dat of niet. [wonen. 
24. Daku mo lolinga ië. Badju amali kokotu. Mi rapi la i kasuba. Mi nao biru moro. Tjitjikode ledja-ledja. Sio, ngali mi djamani.

25. Daire i langi-langi.

Ta horo ie limau.

Lako ta goleuika.

Guru mi kadato dia.

Mi dola ake ma njeku.

Ngara po dorari ngolo.

Mi ngale-ngale guratji.

Mi djodjoko paramata.

26. Igo bula hutu moi.

I ahu rame ma doja.

I djanga si fo sigutji.

I laka fo sidoniru.

27. Ma wange i lobi-lobi.

Dia se mo roka hoko.

Mi beleti sorowai.

Ami leru ubo-ubo.

Mo sitola ubo dadu.

Mo silolifu manuru.

Mo sirangi dagasuli.

Dagasuli mo dodoha.

Ma roka doka mo hoko.

Ali! to mi keri-keri!

28. Sio! hena hutu moi.

I ahu rame ma doja. Ma dubo i ni guratji.
Daar boven gaat zij omhoog. Met een kostbaar zwart baadje. Haar sarong is rood.

Haar uitzicht is prachtig blauw. Haar haarspelden schitteren.

Helaas, haar gelaat verandert.

Het wordt licht over zee.

Ik roei noordwaarts naar de stad. Ik geef mijn oogen den kost. Goeroe haar paleis is landwaarts. Zij klimt op naar het water boven. De deur is tegenover de zee. Haar trappen zijn van goud. Haar sporten van edelgesteente.

Een gele klapperboom.

Komt op op het feest.

Is hij mooi, dan halen we hem [naar beneden.

Is hij goed dan spelen,wij er mee.

De zon is bewolkt.

Ze wandelt van 't land naar zee.

Haar haarwrong is wilde peter[selie.

Haar bloemen zijn oebo-oebo[bloemen.

Zij mengt ze met lichtroode.

$\mathrm{Zij}$ doet er manoeroebloemen bij. Zij behangt zich met dagasoeli[bloemen. Haar laatste is dagasoelibloemen. $\mathrm{Zij}$ wandelt gindsch naar zee. Wel wel! ik bezie haar met [bewondering!

Helaas, een pinangboom. Komt op op het feest. De top is u van goud. 
Ma rau ka paramata.

Ma sofo tara guratji.

I doro-doro salaka.

29. Lulu dia, lulu dai.

Lulu se fira mi ngoko. Fira mi demo ma dofu. Mo ginado toma kore. Ha lulu bawo ma gito. Daka mo ma goru-goru.

30. Mula-mula legu-legu. Sigado futu konora. Mo na bailelua.

Iti ka laha mi sio. Mi gogoru ngale moi.

31. Dodagi mo ledja-ledja. Ledja mo tjotjahaia. Luri ja tike ma djou. Auali no bobapo.

Tjoba no bobapo giki.
De bladeren als edelgesteente. De vruchten (hangen naar)

[beneden als goud.

$\mathrm{Zij}$ vallen af als zilver.

Rollen landwaarts, rollen zee-

[waarts.

Rollen op de zuster haar weg. De zuster haar woorden zijn vele. $Z$ ij vraagt aan den wind.

De stroomrafeling rolt.

Daar zit zij te peinzen.

Eerst het legoe-legoe-spel spelen. Tot aan middernacht.

$Z$ ij danst niet om ons heen.

Als maar haar beklag goed is.

Haar liefde een reden (voorwerp)

[heeft.

Gaande blinkt ze.

Zij blinkt en schittert.

De loeri zoekt de heer.

Ook goed als gij dichtbij komt. Probeer om dicht bij de lui

te komen.

La ma njinga dokangare. Opdat zij gindsch het gedenkt.

32. Daka ma gudu to ino. Daar van ver kom ik.

Ino to ma wasu laha. Ik kom om het werkelijk goed

$[($ te weten $)$.

Ta paratada ni gamu. Ik bewaak Uw stad.

Ta fakiri ni limau. Ik pas op Uw hoofdstad.

Ta sadaha ni kadato. Ik bewaak Uw paleis.

Ta totaua ma ngale. Ik geef er nog geen rede van [(waarom).

Dofutu bolo madiri. Morgen of overmorgen.

Suba no sosere. afa. Belach niet mijn begroeting.

33. Ngitu dia ngitu dai. Misschien landwaarts, misschien

[zeewaarts.

Ngitu dai toma gura. Misschienzeewaartsopheteiland. 
Lohoko mi sora hoko. Met den landwind varen we [zeewaarts.

Mi oti turi ma bunga. Haar prauw is een toeribloem. Mi sari kelo ma rau. Haar schepper een kelor blad. Mi side gabi ma boro. Haar zeil is een gabibloem. Mi lebi hutu ma ngai. Haar schoottouw een haar.

34. Ma roro ma gudu eni. Lang geleden ben ik van verre [hier gekomenKara ta djoko ni gamu. Nu pas betreed ik uw stad. Gamu ne kie kolano. Deze stad is de stad des konings. $\mathrm{Ri}$ mahe ri golofino. Ik ben beschaamd en ik vrees. Ruku tara si loloa. Felaië suba djou. Ik buig beleefdelijk het hoofd. En beur het op den Heer

[groetende.

35. Ni hira, to tego gudu. Gij zusters ik woon ver weg. Tomangola ma sonanga. Aan de overzijde der zee. Dara i sorota mote. Ik volg de vliegende vogels. Ta pane ni doka nena. Ik klim op naar dit uw dorp. Ta laku ni soa njië. Ik verwin(?) uw voorgaanderij. Ta roka ino ni gamu. Ik wandel door uw stad. Tjita ka ma dodjoua. Jammer dat (ik) niet waardig ben.

36. Ta mote ma djela-djela. Ik volg het djela-djela gras. Mara i tarangi fodi. Maar het is verbazend mooi. Limau hena ma dehe. De stad aan de pinangkaap. La ma dadita sonanga. Opdat ik er maar dadelijk blijve.

37. Dai ma ngongadje isa. Van over zee kwam het bericht. Surat Guru mo lefo. Vrouw Goeroe heeft een brief [geschreven. Kadari ma ronga njawa. Als het maar (aan) iemand is. Iti ni ma moi-moi. Al was het (aan) u allen.

Manuru to silololoa. Ik betuig eerbied aan de manoe[roebloem.

Saja gabi to kodiho. Ik breng de gabibloem terug.

De manier waarop men dit, al trekkende aan het touw, zingt, is zoo: de mannen zingen: Daka ma gudu to ino; alleen de rrouwen, ook wel mannen en vrouwen zingen nu: du to ino, wela-wela, en zoo verder: 
Ta torusu rame nena - ramenena, wela-wela.

Rame ne, laha marua - ha marua, wela-wela, enz.

1. ma dorusu: bezoekers; wako verkort van djolow ako: het is beter dat.

2. ledja-ledja: blinken; vooral op een feest, worden de vronwen soms zoo opgetooid, met allerlei loovertjes, dat zij werkelijk schitteren, blinken.

6. la u : kunsten, ook wel: streken, kuren.

7. kai-sikai: huwelijk, huwen. Tern. van kahwin. Mal.

9. iko genomen als ikoet: volgen. Mal.

10. mididi, pers. vorm van romdidi: twee. Tern. ri lako: mijn oogen; wellicht moet dat zijn mi lako: haar oogen.

11. ho ma kuto: zich opschikken; lolaise: ik weet niet wat dat is. sisasade, opgevat als verternataanschte uitspraak van sitjotjade: boerten, begekken; veel zin geeft het echter niet.

12. nuru, verkort van manuru; gulu-gulu: van verre. Tid.; manuru djawa moloku: of dit werkelijk een soort manuru is, weet ik niet.

16. liko-liko is een soort touwtjespringen, en ik heb aangenomen, dat dàt bedoeld is; het woord beteekent ook: hangen, maar dat geeft geen zin.

18. Doka dara toma ngolo; missohien: ho ka dara toma ngolo.

21. Djolo bidji: een speling van djolowako: het is beter dat.

22. or a jo ini, misschien ara $\mathrm{ja}$ ini.

i soru, ook mogelijk dat bedoeld is: ik ga mede op zijn weg.

23. lululele: een soort uitroep om de aandacht der verzamelden te trekken.

26. ig obula: gele of witte cocosnoot; i a hu: opkomen, groeien.

29. lulu: waarschijnlijk het rollen der golven; halulu bawo ma gito; er stond halale, maar daar weet ik geen zin van te maken. Ik geloof wel dat bawo ma gito stroomrafeling beteekent, maar ik weet het niet zeker.

30. mo na baileleua: a.g.z. iemand die krijgsdanst, al dansend omringd wordt door de schoondochters, om hen te eeren, beteekent dit misschien: zij veronachtzaamt ons.

31. Ik weet niet of de vertaling der drie laatste regels van dit vers goed is, maar ik weet geen betere.

32. ta fakiri; hierbij is wel gedacht aan de legenden, waarin altijd een oud vrouwtje: ngo fakiri, optreedt als „putbewaakster; sadaha, titel van een soort Hoofden.

35. ta laku: ik verwin. Misschien wel niet goed, maar ik weet er niets beters van te maken.

tjita ka ma enz.; tjita verkort van duka-tjita. Mal.

36. i tarangi fodi, eigenlijk: heel mooi licht; maar men zegt het ook om een feest op te hemelen.

37. De laatste regels zouden ook kunnen beduiden: de manuru betuig ik eerbied, ik, die maar gabi ben, keer maar terug.

Dat het wela-wela geen Tobeloreesch spel is, maar uitsluitend Galelareesch, wordt door het overwegend Galelareesche van de taal wel bewezen. 


\section{Raadsels.}

Hier volgen nog eenige raadsels, ma tjumu-tjumu. Zij worden bij allerlei gelegenheden gebezigd, wellicht wel het meest tijdens de doodenfeesten, om elkaar 's nachts den slaap uit de oogen te houden.

1. oguratji ha umo, o häàka ha lè.

ma romanga: o lukama.

het goud wegwerpen, het zilver nemen.

antwoord: de langsapvrucht (waarvan men de geele schil wegwerpt, en het witte vruchtvleesch eet).

2. o aili, ma haeke o guratji.

ma romanga: o hilo.

een duizendpoot met gouden kop.

antwoord: een fakkel.

3. ma bikini hoka mabikini, mahaekehokamahaeke.

ma romanga: o hiha.

zijn staart zooals een staart, zijn hoofd zooals een hoofd. antwoord: een boomschors- schaamtegordel. (het uiteinde daarvan heet: de staart, het voorstuk: het hoofd. Is het kleedingstuk nu in gebruik, dan hangt het stuk, de staart van achteren af, en het stuk: het hoofd van voren.

4. o kohe i lotaka ma tūhu koiwa, o kaibi i lotaka de ma tuhoka.

ma romanga: o kudohu de o pinowa.

een jaarvogel valt zonder knal, een kwikstaartje valt met een knal.

antwoord: de bladscheede van den arenpalm en van de pinangpalm (de eerste is heel groot, maar zacht, de laatste is betrekkelijk klein, maar hard, zoodat de eerste zonder hoorbare plof valt, de laatste daarentegen er mede.

5. o ngohakohi de i mangoere, de ja lamoko i ma ngoerua.

ma romanga: o tiba ma gahata.

nog kind met een sarong, groot geworden, er zonder.

antwoord: de bladkoker van de bamboe. (een nieuw uitschietende bamboegeleding zit in een bladkoker, die er echter op den duur afvalt.

6. o ria dodoto ja hinoto i ma rihimangino, ka hiadono i honenge, i ma temoua.: 
ma romanga: o ngotiri ma kalulu.

twee broeders staan tegenover elkaar, tot ze sterven spreken ze niet met elkaar:

antwoord: de voor en achter op de prauw geplaatste verlengstukken van de kiel (zie «Vaartuigen».)

7. o njawa mo ma tengoka ka mo temoua, de ja hinotoka ja temo.

ma romanga: o bobili.

een mensch alleen maar zegt niets, met hun beiden praten ze. antwoord: armringen (die natuurlijk rammelen, als er meer dan een is.)

8. o njawa ge onanga utu o moholeheohi ja temo ua, de ja timonoka jo temo-temo;

ma romanga o igono ma hohoko.

sommige menschen spreken niet als ze nog maagd zijn, en als ze oud zijn, spreken ze;

antwoord: een kokosnoot. (als die nog jong is, is hij gevuld met vocht, en klokt niet, bij 't schudden; wordt hij rijp, dan vermindert het vocht erin, en nu klokt hij wel.

9. o gofao ngai moi ha olomoha mata ua;

ma romanga o dudu.

een gofao (een klein vischje) eten, en het niet opmaken: antwoord: een sigaretje, (waarvan men natuurlijk het eindje wegwerpt.)

10. o häaka de o guratji i maka-ganu;

ma romanga: o gohi.

zilver en goud met elkaar vermengd;

antwoord: een ei.

11. o tiba o dengo moi, ha hangaini h'adonua;

ma romanga: nanga pangaa.

een bamboegeleding, waar men de hand niet in kan steken; antwoord: de elleboog. (de aardigheid zit er in, dat bamboe en de ellepijp beiden "tiba" heeten.

12. o njawa ja hinoto ja uti,ja motoa ja dahongo;

ma romanga: o hirangutu.

twee lui dalen af, vijf lui vangen ze op;

antwoord: neusslijm. (men gebruikt natuurlijk de vingers als zakdoek.

13. Wo ma tengo o kopanjioka, wo ma ohiki o humuku de wa oahoka; 
ma romanga: o igono ma goa.

een Hollander baadt zich in een put, en komt droog te liggen; antwoordt: een klapperspruit (die is wit en ligt aanvankelijk in het cocosvocht, maar dat droogt op den duur op.)

14. O njawa ja ruange jo wohama okota ma goronaie, jo hupu oka, mangabionoka moi;

ma romanga: o mokuru de o bidoho de o dofae.

drie lui gaan een vesting binnen, als ze er uit komen hebben ze allen hetzelfde voorkomen; antwoord: pinang, sirih en kalk. (die bij het pinangkauwen achtereenvolgens in den mond gestoken worden.)

15. o tau moi, ma liate ka moioka;

ma romanga: o paju.

een huis met maar één paal; antwoord: een regen of zonnescherm.

16. o gota moi, ma hohoko ka ma giria;

ma romanga: o djaa.

een boom met heel veel vruchten; antwoord: een werpnet;

(ik weet niet of men hierbij aan de mazen van het net denkt, dan wel aan de looden ringen, die er rondom aan bevestigd zijn.

17. ma hoka o garegadji, ma hohoko n marětèlu;

ma romanga: o nanahi.

de bladen zijn zagen, de vrucht een hamer; antwoord: de ananas.

18. ma Tuang w'olomo o roti, ma wa mata-ua;

ma romanga: o gogihoro.

een heer eet brood maar hij !maakt het niet op; antwoord: de tandenvijl.

19. o gilaungu hange wi moku ma moi o koano;

ma romanga: o hidete.

drie slaven dragen tezamen één koning; antwoord: het zeil (dat hangt aan de driepootige mast) (zie «Vaartuigen»).

20. o boki o karahi ja giniki, ma ja daenua;

ma romanga: o ngotiri i hidete.

de kat achtervolgt een muis, zonder die te krijgen; antwoord: een prauw met zijn zeil.

21. ngoni ajomo honenge, okia mo ni gumala;

ma romanga: ami romanga: 
als je moeder sterft, wat laat ze je dan na; antwoord: haar naam. (dit schijnt wel haast een satire op de betrekkelijke bezitloosheid van de gehuwde vrouw, hoewel ik niet zeker weet, of dit er mee bedoeld wordt).

22. ngoni ajo mo honenge, no ariua, o totaleo ma gare-garehe i honenge, no ariua;

\section{ma romanga: o uku ma noho.}

je moeder sterft, je weent niet, een witte kip sterft, je weent niet, antwoord: de rook. (heel duidelijk is mij dit niet).

23. na dodoa genanga no hingohama de no hihupuokali de ma dodogumua.

ma romanga: ho womaha.

wat is het, dat je naar binnen brengt en weer naar buiten brengt zonder ophouden? antwoord: ademhalen. 